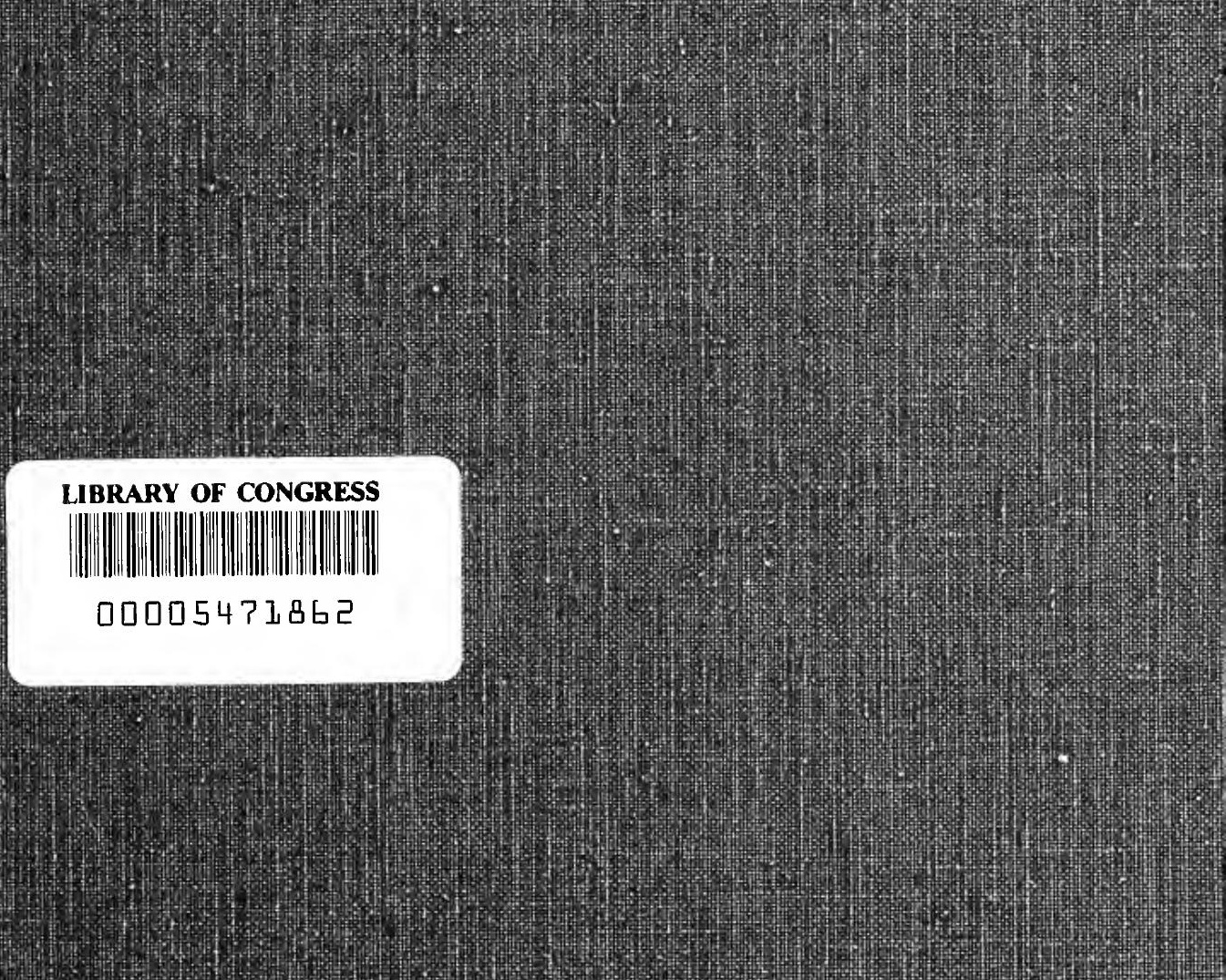






The Publication Committee of the Grolier Club certify that this copy is one of an edition of three hundred and sixty copies on Italian hand-made paper, and three copies on vellum, all of which were printed in the month of November, I 892 . 


\section{.}


BARONS OF THE POTOMACK AND THE RAPPAHANNOCK 
r 


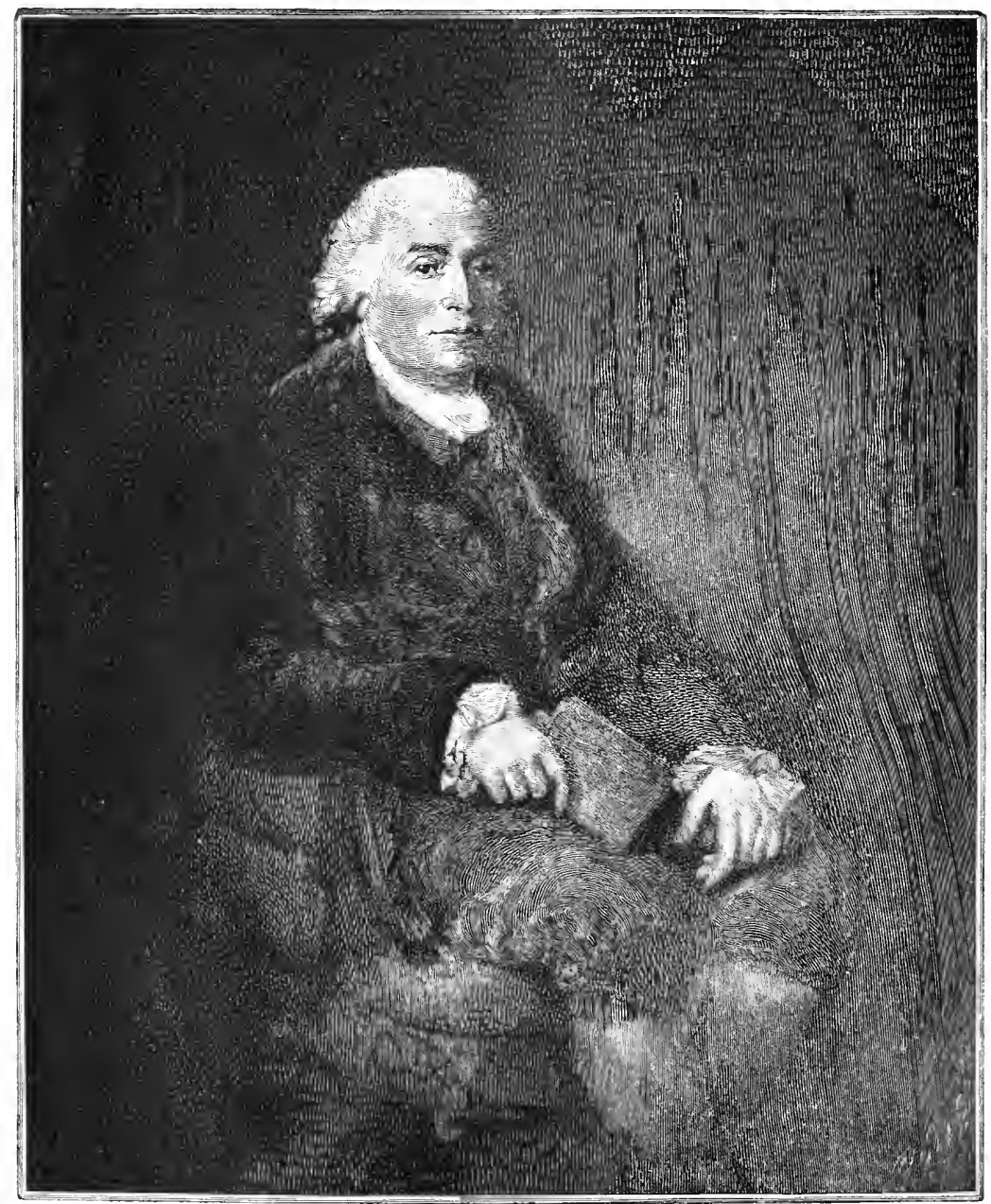

LORD THOMAS FAIRFAX. 


\title{
BARONS OF THE POTOMACK
}

\section{AND THE RAPPAHANNOCK}

\author{
\% \\ BY \\ MONCURE DANIEL CONWAY
}

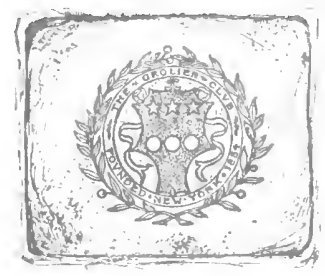

NEW YORK

THE GROLIER CLUB

1892 
Copyright, 1892,

By the Grolier Club. 


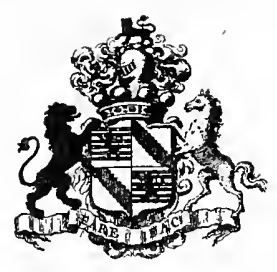

\section{PREFACE}

Among the pretty legends of Spotswood that lingered on the Rappahannock, one related that he had sailed up the river on a ship made musical with English skylarks. He released these feathered colonists in the meadows, just below the Falls, in Spottsylvania, the county bearing his name. In childhood, daily passing those meadows on my way to school in Fredericksburg, how often did 1 hear those larks singing in the morning sunshine! But our elders used to smile incredulously at such tales, and the skylarks were heard more rarely in boyhood. When youth was reached they had all changed to mere meadow-larks. But no doubt other children continued to hear them until they were scared away by the hurtling shot and shell which left their happy homes desolate monuments of civil war.

The legendary larks still sing, however, in their 
mystical heaven, for those who can revive and realize in imagination the colonial childhood that first heard their song. They are winged symbols of the happier ways of English life, which the good governor and his cavaliers tried to import, but could not acclimate amid the prosaic necessities and puritanical customs that gradually turned their melodies into killdee screams. But now and then from some old colonial letter 1 see the English lark soaring up again, and hear his requiem of a generation of Virginia gentlemen and gentlewomen, long past and buried, whose successors can only know in moldering parchment the brave life they lived on mountain, field, and stream, in their ancient régime, forever extinct. Such letters, however, with the heart of English Virginia in them, are rarely found, and it is like coming on a whole choir of the old governor's songsters to read those for the first time printed in this volume.

Or perhaps I should say orchestra rather than choir ; for in these manuscripts, which have found their way into the collection of Mr. William F. Havemeyer of New York, we surprise an undress rehearsal of the prologue to our Revolutionary drama. On a stage beyond the misleading lights of patriotic prejudice, and hitherto but dimly lit by any lights at all, the unconscious dramatis personce appear,-light-hearted youths, loyal and happy 
in their imported English habitat, little dreaming that it is passing away and their manhood pledged to America Some of the writers of these letters have hitherto been little more than imposing names in genealogical tables, others conventionalized into unreal figures of our national wall-paper. My reader shall see some living forms descending from that historic upholstery, and names climbing down from family trees to tell how they got there.

These letters and manuscripts tell, indeed, no continuous story; they are unconnected, fragmentary, full of references to a variety of persons and affairs in a remote colonial period hitherto interesting mainly to the genealogist and the antiquary. The papers make some new paths for the historian and the biographer, but such multiplicity of persons, places, and events admits of no integral literary treatment. The interest is essentially, and not by mere metaphor, dramatic; but the scenes that succeed one another belong to separate plots, each requiring the recovery of some situation to explain its motive, action, and references. They are connected only by the political and social, regime which included the various aims and enterprises of the time, like a stationary scenery. Of this some account and description must be given. 1 bring, too, some footlights from family history, glimpses into the old homes of these 
early Virginians, and what local lore I can gather for realistic presentation; but the mounting must mainly be on each reader's own historic imagination. That imagination 1 endeavor to assist by some preliminary studies of the events which gave our Barons of the Potomack and the Rappahannock their political and social environment, and the issues with which they were concerned. For the rest, although the main object of this work is not historical, 1 have availed myself of this opportunity to utilize some unpublished discoveries concerning the Washington and Lewis families especially, and to surround the epistolary portraits with appropriate frames.

If personal sentiment becomes too apparent in any of these pages, let the reader be indulgent. The ramble into colonial times has involved a ramble amid the scenes and associations of my boyhood. A hundred years after the decade chiefly revived in these manuscripts $(1740-1750)$ the descendants of those famous Virginians were my schoolmates; in the old playgrounds were still young Washingtons, Lewises, Willises, Bassetts, Fitzhughs, Masons, Maryes; we sported in the same streams, and gathered cherries with deep conviction that Washington never harmed any such tree; we were greeted by venerable gentlemen and ladies,-Mrs. Dunbar, Judge Lomax, Byrd Willis, Basil 
Gordon, - who in childhood had been greeted by Mary Washington and her illustrious son. Colonial manners and ideas had largely survived, and this masquerade of earlier Shades in vestments of memory is too real not to awaken emotion in those who feel themselves the last witnesses of a Virginia forever irrecoverable.

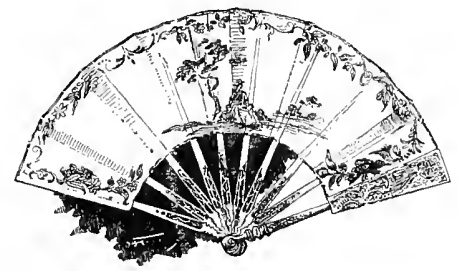


. 


\section{CONTENTS}

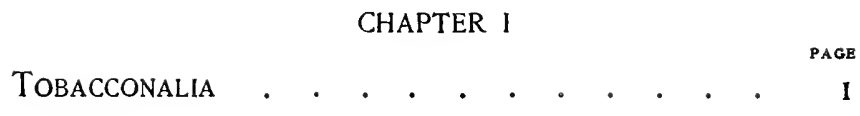

CHAPTER II

Spotswood and the Cavaliers . . . . . . . 16

CHAPTER III

"ARMS, AND THE MAN" . . . . . . . 32

CHAPTER IV

Augustine Washington And his Family . . . 44

CHAPTER V

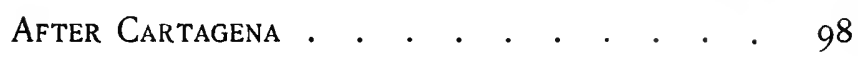

CHAPTER VI

The Virginians . . . . . . . . . . . 114

CHAPTER VII

WARNER HALl . . . . . . . . . . 144

xiii 
CHAPTER IX

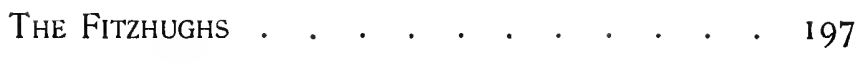

CHAPTER $\mathrm{X}$

A Lord And a Lad at Belvolr . . . . . . 211

CHAPTER XI

The Fairfax Stone . . . . . . . . . 235

CHAPTER XII

Mount Vernon, and Young Virginia . . . 255 


\section{ILLUSTRATIONS}

Facsimile of Fairfax Coat of Arms . Device on Cover

From the original map, "Survey of Northern

Neck of Virginia, 1736-1737"; in possession of Mr. W. F. Havemeyer.

LORd Thomas Fairfax . . . . . . . Frontispiece

Photograph from original oil-painting in Alexandria Washington Lodge, No. 22, A. F. and

A. M. Engraved by R. G. Tietze.

View of Old Bruton Parish Church, WilliamsBURG, VA. . . . . . . . . . . I 8

Drawn by HARRY FENN, from photograph lent

by Mrs. Cynthia B. T. Coleman. Engraved by

C. Schwarzburger.

Washington Arms on Church at Warton (showing shield) . . . . . . . . 35

Drawn by HaRRY FenN, from photograph.

Facsimile of George Washington Letter, dated May 5, I 749, to Major LaWrence WashINGTON, AT WILLIAMSBURG, VA. • . . 96

Original in possession of Mr. W. F. Havemeyer.

Facsimile of Superscription on LetTer from George

Washington to Major LaWRence WashINGTON • • . . . . . . . • • • .

Original in possession of Mr. W. F. Havemeyer. 
xvi

Sabine Hall, Warsaw, Richmond County, Va. . 138

Drawn by HARRY Fens, from photograph lent by Mr. Robert C. Wellford.

MARY Howell . . . . . . . . . . 158

From replica owned by Mr. Coleman G. Williams.

Original in possession of Miss Susan Douthat of Buchanan, Botetourt Co., Va. Engraved by R. G.

Tietze.

Deborah Clarke, Second Wife of Hon. William Fairfax . . . . . . . . . . . 214

From the original oil-painting in the Essex Institute, Salem, Mass. Engraved by R. G. Tietze.

Facsimile of Fairfax LetTer, dated November 10, 1773 . . . . . . . . . . 247

Original in possession of Mr. W. F. Havemeyer.

LAWRENCE WASHINGTON (with signature) • • 255

From original oil-painting owned by Lawrence Washington, of Alexandria, Va. Engraved by

R. G. Tietze. 


\section{HEAD AND TAIL PIECES \\ DESIGNED AND DRAWN BY HARRY FENN}

CHAPTER I. Tobacconalia. Pipes, tobacco leaves and flowers. Tail-piece, tobacco plant and pipes.

CHAPTER II. Spotswood and the Cavaliers. Horseshoe and oak branches. Tail-piece, bird and Virginia creeper.

CHAPTER III. "ARMS, AND THE MAN." (Heraldic, anent the Washingtons.) Fourteenth-century shield and wreath, showing cinquefoils; seal of Augustine Washington; impression of George Washington's private wax seal. Tail-piece, arms of Barons Washington, from design sent by the present Baron Washington of Munich; painted by his nephew, Stefan Washington, LL. D.

CHAPTER IV. Augustine Washington and his Family. A single ship. Tail-piece, seal of Augustine Washington on letter to Major Lawrence Washington; drawn by OTTO BACHER, from original in possession of Mr. W. F. Havemeyer.

Chapter V. After Cartagena. Four ships.

CHAPTER VI. The VIRGINiAns. Virginia creeper and mocking-bird.

CHAPTER VII. Warner Hall. Crabs, fish, and flowers. Tail-piece, Lewis arms, from an engraving owned by Captain Henry Howell Lewis, Baltimore, Md.

CHAPTER VIII. WORD-FOSSILS AND FOLK-LORE. Sea-horses and seaweed. Tail-piece, shell and seaweed.

CHAPTER IX. The Fitzhughs. Old letters. Tail-piece, Fitzhugh seal.

CHAPTER X. A Lord AND a LAD At Belvorr. Heraldic design. Tail-piece, shield.

CHAPTER XI. The Fairfax Stone. Roses, etc. Tail-piece, the Fairfax Stone.

CHAPTER XIl. Mount Vernon, and Young Virginia. Ornamental design from Greek jug. Tail-piece, andirons from Mount Vernon. 
. 


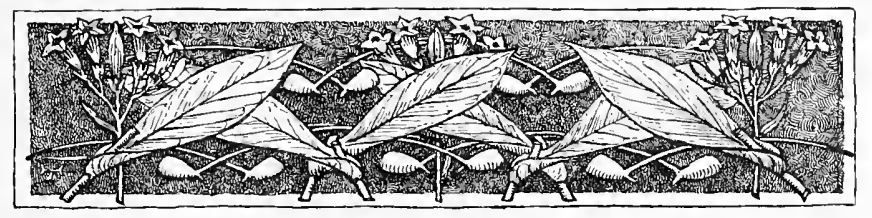

\section{BARONS OF THE POTOMACK AND \\ THE RAPPAHANNOCK}

\section{Tobacconalia}

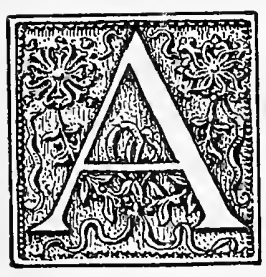

FEW years ago, when Americans were sending to the press their sentimental suffrages for a national floral emblem, the true one found no favor-Tobacco. Its rosy flower is not unlovely; but had it been proposed an army of pious men and a host of ladies would have risen in wrath. Yet religion and tobacco are ancient allies. I asked an eminent Southern 
Methodist why it was that, after the Union was politically restored, the sectional division in his church could not terminate. He fenced with my question for a time, but at last confessed that the wall of partition is built of tobacco. "Those Northern Methodists forbid their preachers to smoke, and are engaged in a general crusade against tobacco. That is our Southern staple, and our churches are largely supported by it." As for our ladies, they may cry for equal political power, but even the franchise, did they obtain it, could not give it to them so long as the insurmountable cigar bars their way to the clubs and conclaves in which candidatures are determined and party treaties made by the calumet, as they were made by aboriginal tribes in the days of the good chief Tammany, who is among "the undying ones."

A true history of tobacco would be the history of English and American liberty.

When Columbus reached the West Indies he found the gentle natives smoking their primitive cigars, - rolls of tobacco wrapped in leaves of the maize, - and when he asked for the golden treasures he was seeking, they answered, "We have a plant that destroys care." But it was just that care-destroying 
plant which two centuries later enthroned Care beside the British monarch. James I. was termed by Sully "the wisest fool in Christendom." His wisdom was to recognize Tobacco as a rival potentate, his folly to try and make it minister to Prerogative. There was a republic of letters in London, and its president, William Shakespeare, whose pipe is still preserved at Stratford-upon-Avon, enjoyed it with his circle all the more for reading in the King's "Counterblaste to Tobacco" that its fumes resembled "the horrible Stygian smoke of the pit that is bottomless." But into that pit James pitched his prerogative when he endeavored to draw a revenue for the Crown from the "pernicious weed." He was checked by a resolution of the House of Commons. The long contest which ultimately transferred purse and sword from Crown to Commons began with the tobacco question.

Had the English commoners been as careful of constitutional rights in their colonies as at home, the American Revolution had never occurred. That revolution really began with resistance to irritating duties and regulations imposed on the cultivation of tobacco in Virginia. After some tobacco riots, followed 
by executions for treason, loyalty in the colony diminished. And presently the wonderful plant involved religion also. Those who mainly kept loyalty alive in Virginia were the clergy of the Established Church, and they were entirely supported by tobacco. "The Establishment indeed is Tobacco." Such were the pregnant words of the Rev. Hugh Jones, A. M., in his pamphlet on "The Present State of Virginia." That was in I724. The noble lords in London, who controlled the plantations in Virginia, could hardly comprehend the clergyman's singular sentence. Lords before them had been told that Virginian souls were neglected, and had given the memorable reply: "Damn their souls, let them make Tobacco." And they did make tobacco, but it was found that this staple steadily grew strong enough to damn their lordships.

Early in the eighteenth century tobacco had become the currency of the colony. By a law of 1696 the salary of every clergyman had been fixed at sixteen thousand pounds of tobacco per annum. But the value of such salary was variable, by reason of changes in the market-price, consequent on the quantity shipped to Europe, and also on account of 
the quality of the tobacco. In some parishes only "Orinoco" could be raised, which was inferior to "sweet-scented." Many a poor clergyman's household was filled with joy at tidings of his promotion from an "Orinoco parish" to a "sweet-scented parish," as they are described in the old books. But there were many parishes where no tobacco could be cultivated at all, and these were left entirely without ministrations of the Established Church. But in these tobaccoless wildernesses voices were heard of the Baptists, Quakers, or less definable dissenters, who were directing the pioneer's axe to the root of the established Tree that protected the throne. In some of these neglected parishes stood old church edifices, and these were freely utilized by any peripatetic ranter or rabid separatist who might come along. Even the wandering "parsons" connected with the establishment were often illiterate, there being no American episcopate, and theological education and ordination remaining transatlantic luxuries.

Historians of the American Episcopal Church have been somewhat severe upon the English Church for not earlier appointing an episcopate in the colonies, especially in Virginia. 
This was indeed inconvenient, as ministers had to repair to England personally for ordination. But the failure was not altogether, perhaps not mainly, due to the English Church. The Virginians, loyal churchmen as they generally were, even when unorthodox, dreaded the establishment among them of bishops' courts, looking upon them as a sort of Inquisition. And indeed, if a bishop in Virginia had magnified his office in the same way as the governor, the dread of him was not unfounded. However that may be, there appears no doubt that, in the absence of any near authoritative superintendence, the clerical administration showed some curious developments. The clerk, chosen by the vestry, became an important personage. When the clergyman was ill the clerk officiated, and sometimes introduced strange doctrines, as well as language not "sweetscented," into the pulpit. If the clergyman died, the clerk became de facto parson, and might long remain such. He often appears as the rival rather than the assistant of the clergyman, this giving rise to sharp divisions such as that in Truro parish, mentioned in a letter of William Fairfax (August 15, 1749) printed on a farther page. 
It should be stated, however, that many churches, perhaps a majority, did a good deal of missionary work, sending out "readers" far and near to conduct services and read sermons. In studying the vestry-book of St. George's parish, whose centre was Fredericksburg, I have found it amusing to note the care with which the vestrymen made their reports of counting the tobacco-plants. Every plant in the county of Spottsylvania was counted as if each were a pound sterling in a bank. The services done by these plants are shown in the following parish account for one year:

Dr. Lbs. of Tobacco.

To Rev. James Marye, his salary per year . . 16,000

To George Carter, Reader at Mattapony . . . I, ooo

To R. Stuart, Reader at Rappahannock . . . I, ,oo

To Readers at Germanna and the Chapel . . 2,00o

To Zachary Lewis, for prosecuting all suits for the parish, per annum . . . . . . . 500

To Mary Day, a poor woman . . . . . . 350

To Mrs. Livingston, for salivating a poor woman, promising to cure her again if she should be sick again in twelve month 1,000

To James Atkins, a poor man . . . . . . 550

To M. Bolton, for keeping a bastard child a year . . . . . . . . . . . . . 800

To John Taliaferro, for three surplices . . $\quad$ 5,000 
To Wm. Philips, Reader at the Mountain - 325

To John Gordon, sexton at Germanna . . 5,000

To John Taliaferro, for keeping a poor girl six months . . . . . . . . . . . 1,000

To Edmund Herndon, for maintaining Thomas Moor... . . . . . . . . . 800

$\mathrm{Cr}$.

I 500 tythables, at $22 \mathrm{lbs}$. of tobacco per poll 33,000

175 tythables employed in Spottswood's Iron Works, exempted by law from paying tythes.

There was something in the life of a planter that tended to foster a spirit of independence. He lived at the centre of a large estate, not under the eye of his peers, patriarchally supreme in his family, surrounded by his white serfs and negro slaves. His word was law. $\mathrm{He}$ and his family were fed from the manybreasted earth; the little they needed from England being easily and surely brought them in exchange for tobacco. They had their proud family traditions, their coats of arms, and were not liable to any snobbish deference toward the officials sent to Williamsburg, whom they rarely saw. For the rest, the swarms of British captains and seamen who sailed between the Potomack or the Rappa- 
hannock and England were not such as could inspire any great esteem for the mother country. The Rappahannock was especially the highroad of the tobacco country, and trading-hamlets grew on its banks. They were generally inhabited by the younger sons of the planters, who rapidly accumulated money by attending to the shipping business. The town of Fredericksburg, at the head of navigation, was founded in 1727 , and in it were represented the great families of the Rappahannock.

The first vestry-meeting of St. George's parish (formed 1721) of which there is an entry, occurred on Monday, January 16, 1726, at the Lower Church on the Rappahannock,the year before Fredericksburg was laid out. At that meeting it was "Ordered, that Benjamin Cave and Richard Cheek do examine and enquire of the names and number of persons allowed to Tend Tobacco, according to a late Act of Assembly made for the Better and more Effectual Improving the Staple of Tobacco, and the crops of the several planters, and the number of plants growing on any and every plantation"within a certain precinct. The bounds between precincts were laid off every four 
years. This supervision of the plantations was called "processioning." In St. George's parish, June 27, 1727, Robert Green and Isaac Normin "processioned the land between the river and mountains." These mountains were far away, near the headsprings of the Rappahannock.

Soon after Fredericksburg began to fill up a little, a Scotch-lrish clergyman named Patrick Henry settled there. His story, in connection with his famous nephew of the same name, is told in Mr. Wirt Henry's recent biography of the great orator. The Rev. Patrick Henry came to Fredericksburg in 1733 , and remained little over a year, and it is a striking fact that under his brief ministry St. George's Church began a sort of rebellion against State control. They had engaged the chief founder of the town, Col. Henry Willis (whose wife was George Washington's aunt), to build them a church for seventy-five thousand pounds of tobacco. On the petition of some remote parishioners, the governor (Gooch) made an attempt to interfere, in accordance with his prerogative, with the location; but he had to be satisfied with their explanations; the chief one being that the edifice was nearly completed. It was the right of the governor 
to appoint every minister, and when the Rev. Patrick Henry resigned the Hon. William Gooch sent to Fredericksburg one Rev. Mr. Smith. After hearing him twice, the congregation dismissed Smith and chose for themselves the Rev. James Marye. This admirable man, who was rector from 1735 until his death, in 1767 , was succeeded by his son, who was chosen by a vote of the people of the parish, the governor wisely submitting. It was a time when people were punished for non-attendance at church, and they were resolved to have a voice in the provision of their compulsory spiritual diet.

The Act of 1696, fixing the clergyman's salary at sixteen thousand pounds of tobacco, had been subjected to a good deal of opposition from time to time,- that is, in years when tobacco rose in price,- and in 1748 it was reënacted only after a considerable struggle. The value of tobacco was then $16 s .8 d$. per hundred pounds. This, with the free use of glebes, gave the "sweet-scented" parson a snug little income, and he was very careful to see that his vestrymen counted the plants, and "tended seconds" ( $i$. e., guarded the plants from being gleaned too closely, or thin second growths gathered). They showed a 
pious anxiety to prevent deterioration of the tobacco crop, or of its price, to the injury of Christ's kingdom in Virginia. But in the year 1755 a drought so injured the tobacco crop that the people could not pay their tobacco debts in kind, and the Burgesses passed an act, limited to ten months, enabling debtors to pay such dues and taxes in money, at the rate of $16 s .8 d$. per hundred pounds of tobacco. Tobacco, of course, rose in value, but the only creditors who still demanded payment in kind were some of the clergy. They appealed to the Bishop of London for his aid in having the new act annulled by the King. But the agitation showed that a majority of the clergy were satisfied with the act. In 1758 another short crop caused a similar act (for one year), and this the clergy resolved in Convention to resist. The Rev. John Camm was sent to England to petition for a royal veto, and obtained an order of Council (August 10, 1759) which, the Lords of Trade and Privy Council declared, would render the act void $a b$ initio. With this Camm returned and brought suit to test the validity of the law. The result was an issue between the House of Burgesses and the clergy. The law point involved was reduced 
to a question of the force of an act, signed by the governor, between its date and the King's disapproval. The great test case became that of the Rev. James Maury, of Louisa County, a popular rector who had not opposed the act in 1755, but now brought suit in the county of Hanover - Patrick Henry's county. The case went on until (November 5, 1763) a decision was given favorable to the clergy. But the question was left to the jury as to the damages, - that is, the difference between the money paid Maury, as his salary for one year, and the value of the tobacco he had claimed. This difference was $£ 256$.

The jury awarded the Rev. James Maury one penny. Other defeats of the clergy followed, - the final one being on Camm's appeal to England, in 1767 . The General Court dismissed it on some technical point, without going into its merits, - no doubt, as Mr. Wirt Henry thinks, "a pretext to get rid of a troublesome question, for the discussion of which the times were not then suited." But troublesome questions had been raised by these tobacco cases, which were destined to be settled by the sword. The "Parsons' Case," as it was called, was first heard before Col. John Henry as magistrate, - Patrick 
Henry's father, - the orator's uncle, Rev. Patrick Henry, after whom he was named, being one of the petitioners against the act. Despite these ties to the throne, and to the church of which he was always a member, Lawyer Patrick Henry flamed out with such an arraignment of the clergy, for seeking to grind the suffering people, that he broke their authority, and became the darling of the Presbyterians and other dissenters. Even more momentous was his arraignment of the King. He declared that his disapproval of a necessary colonial act was an instance of oppression by the King; that by it he had degenerated from a father of his people to their tyrant, and forfeited all right to their obedience in regard to a law which could not be annulled without violation of the compact between the throne and the people. The opposing counsel (Lyons) cried out at this point, "The gentleman has spoken treason, and I am astonished that your Worships can hear it without emotion, or any mark of dissatisfaction." There were murmurs in the room of "Treason!" But the bench and the jury sat spellbound by Henry's eloquence, and sanctioned the treason by their nominal damages. The case of the 
colonies against the King was really settled that day. When the Stamp Act agitation presently came, Patrick Henry held the people of Virginia in his hand. Tobacco had built him a throne before which King George had to bend, and by which his sceptre was finally broken. All of which would be more satisfactory had it not come by Virginia's first step in repudiation of her debts.

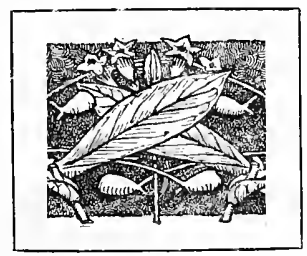




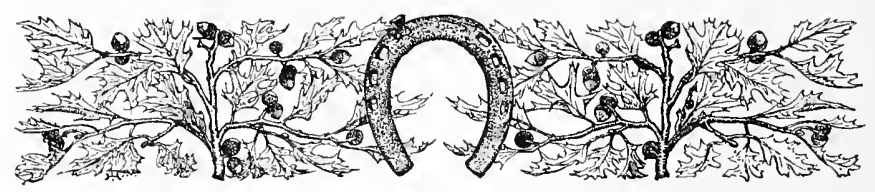

II

\section{Spotswood and the Cavaliers}

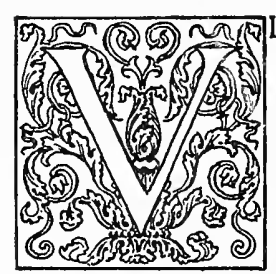

RGINIA, in its three centuries, possesses the unique interest of presenting an epitome of both English and American history. There was a period when the British monarchy existed only in Virginia. When the fugitive Charles II. was a pretender everywhere else, decrees still issued in his name in the "Old Dominion," as it was thenceforth called. Virginia sent Col. Richard Lee to Holland to invite Charles to set up his throne personally in the colony. Some writers think his re- 
fusal was a lucky escape for America, but that may be doubted. He would probably have been rather more liberal than his father, Charles I., who, after he was beheaded in England, continued to be governor of Virginia under one name or another. A colonial governor of Virginia was the prince of pluralists. As representative of the King he appointed all officers, and prorogued at pleasure the Burgesses; as Lord Chief Baron of the Exchequer he dictated to the Council; as Lieutenant-General he directed forces and fortifications on land; as Admiral he disposed of prizes; as Lord Chancellor he decreed causes; as Lord Keeper issued land grants; as the only colonial Bishop he licensed marriages, controlled benefices, appointed or deprived incumbents, settled ecclesiastical causes. One governor and another had made the Virginians realize that these gubernatorial powers were by no means theoretical, though none sprung the whole engine of despotism on the colony.

However, the golden age of every race has for its centre some benevolent or glorious despot, and the Old Dominion is no exception. Probably no monarch in Christendom possessed more absolute powers than Alex- 
ander Spotswood, who, in 1710, at the age of thirty-four, became governor of Virginia. Born in an English colony in Africa, familiar with the slave-trade, bred in the camp, he had courage, enterprise, enthusiasm; but he also had high principle, a sense of honor, and fine intelligence. The Spotswood legend has lasted longer in Virginia than any other. The great sea-fight with Blackbeard the pirate, whose diabolical head was brought up James River as figurehead of an English ship, survives to this day in the folklore of the Virginia coast. The Germans he imported had a curious story, yet to be told, and the town Germanna which he founded on the upper Rappahannock is the haunt of romance. Spotswood was called the "Tubal Cain of Virginia," for he set workmen to mine its iron ores; and his iron age was transmuted into a golden age by his instituting the order of "Knights of the Golden Horseshoe." Or so it passed into the legend of Spotswood's reign, which in actual duration lasted twelve years, in romance never ended.

The earliest mention of the Golden Horseshoe was by the Rev. Hugh Jones, who by Spotswood's appointment preached in pretty Bruton Church at Williamsburg, which the 


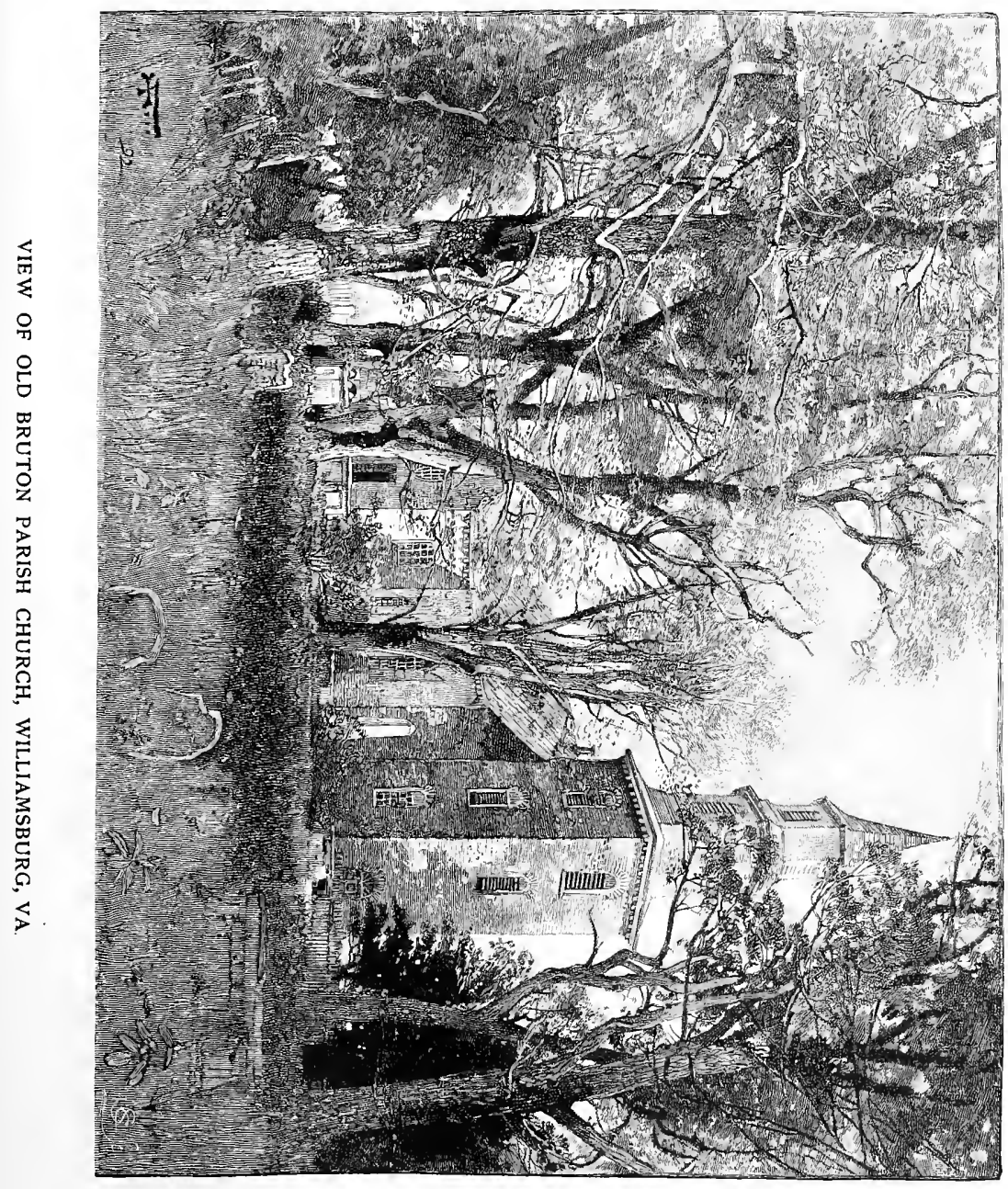


governor transformed from a small structure into what it now is - a monument of his good taste. The clergyman wrote:

"Governor Spotswood, when he undertook the great discovery of a passage over the mountains, attended with a sufficient guard of pioneers and gentlemen, with a supply of provisions, passed these mountains and cut his Majesty's name upon a rock upon the highest of them, naming it Mount George, and in complaisance to him [Alexander Spotswood], the gentlemen called the next mountain to it Mount Alexander. For this expedition, they were obliged to provide a great quantity of horseshoes, things seldom used in the eastern part of Virginia, where there are no stones. Upon which account, the Governor upon his return presented each of his companions with a golden horse-shoe, some of which I have seen, covered with valuable stones, resembling heads of nails, with the inscription 'Sic juvat transcendere montes.' This he instituted to encourage gentlemen to venture backward and make discoveries and settlements, any gentleman being entitled to wear this golden shoe who could prove that he 
had drank his Majesty's health on Mount George."

So unimpressive was the incident at the time that no hint of it is found in any of Spotswood's letters, though he repeatedly alludes to the expedition; and although there were fifty persons in the exploration, and must have been a considerable number of golden horseshoes, not one has rewarded the long search of antiquarians for a specimen. Nothing was heard in Spotswood's time of any "Order" or "Knights"; possibly he and those whom he decorated feared to awaken royal jealousy in England by any such appearance of a gubernatorial fountain of honor. This part of the legend was evolved and decorated by later generations.

The exploration of the Blue Ridge, which touched the imagination of young Virginia, had among its romantic episodes the return with the governor of an Indian maiden, Katena. There are variants of the story: some said that she begged to be carried to the region of the pale-faces; others that she was taken as a voluntary hostage from her father, a chief, for his friendship. At any rate, I have been told by the descendants of Francis Thornton that Katena is not at all mythical, 
and that she became the devoted companion of their ancestor. She used to carry the child into the woods, near the mansion now known as Snowden, on the Falls of the Rappahannock, and taught him the wild arts of her race. On one occasion she was found exhibiting to her charge a number of partridges enticed somehow into a wicker cage which she had made. But Katena died in her eighteenth year, and Francis Thornton remained through life a melancholy man. Her wild and pretty ways became themes of innumerable stories. I have before me a poem by Miss Lomax, - a name found in the Havemeyer letters,- - by which it would appear that Katena may have taught some fair Virginians to swim. I conclude to rescue from oblivion this early poem written by a lover of the Potomack.

"Potomack, in thy silver stream At silent night I love to lave, Unseen, save by the lunar beam, As light I wanton o'er thy wave.

"Here, in thy waters fair reclin'd, I court illusion's changeful sway, To sweet delirium all resign'd, Reality fades fast away. 
"But what soft voice steals on my ear, As wrapt I lie in languid dream? And see! a graceful form draws nearIt is the Genius of the stream.

" 'Mortal!' he cries (his liquid voice Sweet as the blue wave's softest sigh), 'Still are my humid haunts thy choice, Still wilt thou to my green banks hie!

" "When Nature spoke, and this fair flood Rush'd from its dark and secret source, The frowning rock, impervious wood, Alternate bending o'er its course,-

" 'Then rov'd my new-born shores along, The tawny sons of savage life,Here raised the war-whooploud and strong, Here desp'rate met in deadly strife.

" "And here full many a warrior rude In tortures drew his parting breath, But still with spirit unsubdued

Pour'd fearless forth the song of death.

" "Near yon wild willow is the spot

Where oft they formed the mazy ring; And yonder stood the warrior's cot,

Who styled himself Potomack's King. 
" 'There from the sun's meridian ray An oak's broad shadow gave relief, Where oft thy ancestor would stray And woo the daughter of the Chief.

" 'And often that same Indian maid (The white man's bride, as records tell) In childhood's lovely season play'd O'er these soft scenes thou lov'st so well.

" 'At night when Summer's ardent heat O'er all a listless languor leaves, Like thee she sought some cool retreat, And slyly stole amid my waves.

" And often with her rustic bow, When Autumn's varied beauties smil'd, Then to my greenwood sides would go, And wander there a huntress wild.

" "l've seen full many a fleeting race Since then arise to bloom and fade, Through time's illimitable space, And sink in dark oblivion's shade.

" "But none like thee in all that time So oft have sought my lonely shore, So loved my verdant banks to climb, Their mossy beauties to explore. 
" "To none than thee more dear the sight, The music of my noble flood; And none have with more warm delight So oft upon my margin stood.

" "For this I bade yon sycamores

In clusters o'er my beach to rise, And when thou sought'st thy native shores,

To guard thee from intrusive eyes.

" "For this I bid my waters bright

To soothe thy ears with murmurs low, Whene'er by day or silent night

Thou com'st to mark their graceful flow."

Alexander Spotswood was one of the few heroes who lived to find himself legendary. Having got into a conflict with a powerful party headed by Philip Ludwell, involving the rights of the Crown - that is, of the governor - to collate clergymen to benefices, to build forts and other things, poor Spotswood lost his place in 1722 , retreated to Annapolis, Maryland, and passed the remaining eighteen years of his life as a prosaic postmaster-general. The most noticeable event of his subsequent life was his appointment of Benjamin Franklin as postmaster of Penn- 
sylvania. But while he was thus in retreat, so far as Virginia was concerned, the ironmines and furnaces he had promoted, and which bore his name, occupied universal attention, and his various expeditions were still themes of romance and poetry. One of these expeditions had been to Albany, where he made a treaty with the Indians, whose chief he decorated with a golden horseshoe.

The last cavaliers of Virginia - the young Washingtons, Lewises, Fauntleroys, and the rest - were born in Spotswood's time and imbued with his spirit of adventure. When Admiral Vernon was fitting out in England his hostile expedition to South America, the agitation it caused in Virginia was partly due to the chivalrous spirit excited by Spotswood, and to events that occurred under his administration. The belligerent feeling was especially aroused by tidings that Harry Beverley and other Virginians had been captured by the Spanish, and made to work like slaves. When the Virginians were enlisting under Governor Gooch, and Major Lawrence Washington, in his twenty-third year, was beginning his career, Spotswood's cavalier blood stirred. He was now sixty-five years of age, but obtained the commission of a 
major-general. Just as he was about to embark for Carthagena, the old gentleman died. It is said that he was buried near his countryseat at Yorktown, Virginia,-Temple Farm,the house in which, forty-one years later, Lord Cornwallis met George Washington to sign terms of capitulation.

The brief sketch of colonial events here given will enable my reader to appreciate better the general situation amid which the writers of the letters presently quoted found themselves. Let me, in conclusion, relieve the history by a quaint love-story. Spotswood's family were already persons of influence in Virginia. His son John (father of General Alexander and John Spotswood of the Revolution) and his daughter Dorothea married in the Dandridge family; his daughter Kate was a famous belle, but she was rivaled in beauty by the governor's widow. Lady Spotswood, as she was called (née Brayne), was of high rank, her godfather being the Duke of Ormond. After her husband's death (1740), her hand was sought by the Rev. John Thompson of Culpeper. Although attracted by the handsome and accomplished clergyman, the lady could hardly make up her mind to descend from her rank and be- 
come plain Mrs. Thompson. Thereupon the clergyman wrote her a letter, preserved by the Forbes family of Fredericksburg. The letter appeared in Dr. Slaughter's monograph on St. George's parish, but merits wider preservation among the annals of Eros in America. It is dated May, 1742 .

\section{"Madam,}

"By diligently perusing your letter, I perceive there is a material argument, which I ought to have answered; upon wch your strongest objection, against compleating my happiness would seem to depend, viz. That you wou'd incur ye censures of ye world for marrying a person of my station and character. By which I understand that you think it a diminution to your honor and ye Dignity of your Family to marry a person in ye station of a Clergyman. Now, if I can make it appear that ye ministerial office is an employment, in its nature ye most honorable, and in its effects ye most beneficial to mankind I hope your objections will immediately vanish, $\mathrm{y}^{\mathrm{t}}$ you will keep me no longer in suspense and misery, but consummate my happiness.

"I make no doubt, Madam, but yt you will readily grant $\mathrm{yt}^{\mathrm{t}}$ no man can be em- 
ployed in any work more honorable, than what immediately relates to ye King of Kings and Lord of Lords, and to ye salvation of souls, immortal in their nature and redeemed by the Blood of the Son of God. The powers committed to their care cannot be exercised by ye greatest Princes of Heb earth, and it is ye same work i. 14. in kind and is ye same in ye Design of it, wth yt of ye blessed Angels, who are ministering spirits for those who shall be Heirs of Salvation. It is the same Business yt ye Son of God discharged when he condescended to dwell amongst men. Which engages men in ye greatest acts of doing Good, in turning sinners from ye errors of their ways, and by all wise and prudent Means, in gaining Souls unto God. And the faithful and diligent Discharge of this holy Function gives a Title to ye highest Degree of Glory in the next world; for they yt be wise, shall shine as ye brightness of ye Firmament, and Daniel they yt turn many to Righteousxii. 3 .

ness as ye stars for ever and ever.

" All nations, whether learned or ignorant, whether civil or barbarous, have agreed in this as a dictate of natural Reason, to ex- 
press their Reverence for ye Deity, and their Affection to Religion, by bestowing extraordinary Privileges of Honour upon such as administer in holy things, and by providing liberally for their Maintenance. And yt ye Honor due to the holy Function flows from ye Law of Nature, appears from hence: $y^{t}$ in ye earliest Times ye civil and sacred Authority were united in the same Person. Thus Melchisedeck was King and Priest of Salem; and among ye Egyptians ye Priesthood was Æn.3. joined with ye Crown. The Greeks accounted ye Priesthood of equal Dignity with Kingship; wch is taken notice of by Aristotle in several places of his politicks. And among ye Latins we have a testimony of Virgil, yt at ye same time Anias was both Priest and King.

Nay, Moses, himself, who was

Prince of Israel before Aaron was

Ex. xxiv. 6. consecrated, officiated as Priest in yt solemn sacrifice by wch ye Covenant with Israel was confirmed.

"And ye primitive Christians always expressed a mighty value and esteem for their Clergy, as plainly appears by Ecclesiastical History. And even in our Days, as bad as 
ye World is, those of ye Clergy who live up to ye Dignity of their profession, are generally reverenced and esteemed by all religious and well disposed Men.

"From all which, it evidently appears, $\mathrm{yt}^{\mathrm{t}}$ in all Ages and Nations of ye World, whether Jews, Heathens, or Christians, great Honour and Dignity has been always conferred upon ye Clergy. And therefore, Dear Madam, from hence you may infer how absurd and ridiculous, those Gentlemen's Notions are, who wou'd fain persuade you yt marrying with ye Clergy wou'd derogate from ye Honour and Dignity of your Family. Whereas, in strict reasoning the contrary thereof wou'd rather appear, and $\mathrm{yt}^{\mathrm{t}}$ it wou'd very much tend to support ye Honour and Dignity of it. Of this you'll be better convinced, when you consider the Titles of Honour and Respect yt are given to those who are invested wth ye Ministerial Function amply displayed in the Scriptures. Those invested $w^{\text {th }}$ ye character are called ye Ministers of Christ, Stewards of ye Mysteries of God, to whom they have committed ye Word of Reconciliation, ye Glory of Christ, Ambassadors for Christ, in Christ's stead, co-workers with him, Angels 
of the Churches. And when it is moreover declared $\mathrm{y}^{\mathrm{t}}$ whosoever despiseth them, despiseth not Man but God. All which Titles shew yt upon many accounts they stand called, appropriated and devoted to God himself. And therefore, if a Gentleman of this sacred and honourable character should be married to a Lady, though of ye greatest extraction and most excellent personal qualities (which I'm sensible you're endowed with), can be no disgrace to her, nor her family, nor draw ye censures of ye world upon either, for such an action. And therefore Dr Madam, your argument being refuted you can no longer consistently refuse to consummate my happiness.

"John Thompson."

Cupid has rarely taken Scripture texts for his arrows, and in this case he was not blind. On November 9, 1742, Lady Spotswood became Mrs. Thompson.

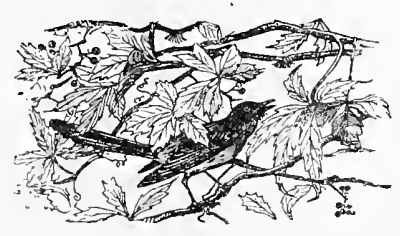




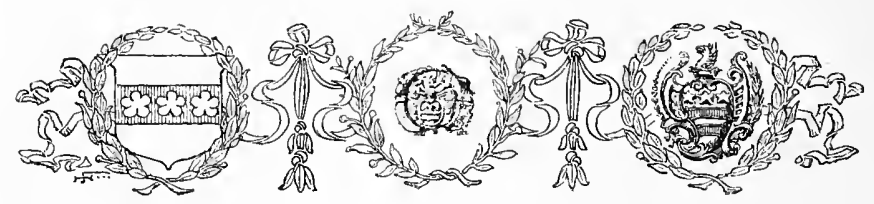

III

"Arms, and the Man"

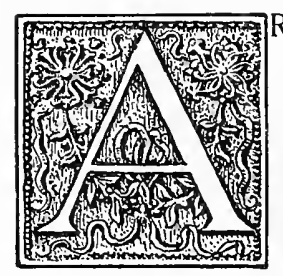

MA VIRUMQUE CANO. SO Virgil begins the Æneid, and his metaphor is in felicitous combination; for in his time the weapon was not independent of the warrior. The weak could not then match the strong, nor the coward defeat the hero, with a death-dealing automaton set at the post of peril. Parallel to this change is that which has come over the heraldic significance of arms. It is no longer possible to connect the man and his coat of arms. Some years before the Revolution, Thomas Jefferson wrote to his London 
agent to try and find his family arms, and, if unsuccessful, to purchase some heraldic device for him; "having Sterne's word for it that a coat of arms may be purchased as cheap as any other coat." A peep of the democratic day is in this incident. The American must not be outdone by any bloated aristocrat of the Old World; he, too, must have his heraldic coat; but whether the coat is his own, or whether it fits him, are unimportant considerations. And to-day how many parade coats of arms which, to the antiquarian eye, are grotesque, as if they were strutting about in dress-coats falling to their heels, enveloping their finger-tips, engulfing their ears!

Of old the arms meant the man. Every coat of arms when originally conferred was a strict record of action done, of service rendered; every modification of such device had historical meaning. There can be no truer illustration of this than the Washington arms. In the thirteenth century there were some Washingtons in County Durham, England, a witness to whose influence remains in the village there bearing their name, but whose personality is traceable only in their arms. These are described in some ancient and 
unpublished manuscripts at Oxford, for the deciphering of which I am indebted to Dr. Nicholson, the Bodleian librarian.

The earliest Washington shield holds: "Gules on a barre argent, 3 Cinquefoiles of ye first." Turning to old books on heraldry, we find that gules, or blood-red, means courage; that argent, or silver, signifies purity, and also that the bearer, though a gentleman, is not of the highest rank. The bar, when single, means the same as a fesse, originally a magisterial belt, later a military sash, meaning that the gentleman had been knighted. The cinquefoil has a meaning first as an herb, indicating that the magistrate or knight was an agriculturist; secondly, as five-leaved, according to Kent's "Banner Display'd," in which occurs the following note: "The number of Leaves in this Herb answers to the five senses of Man; and he that conquers his Affections and Appetites is a worthy Bearer of this Charge, and a greater hero than Cæsar or Alexander; for, as the poet says,

" "When all are conquered greater Glory's won

If by himself the Conqueror's undone.'" 



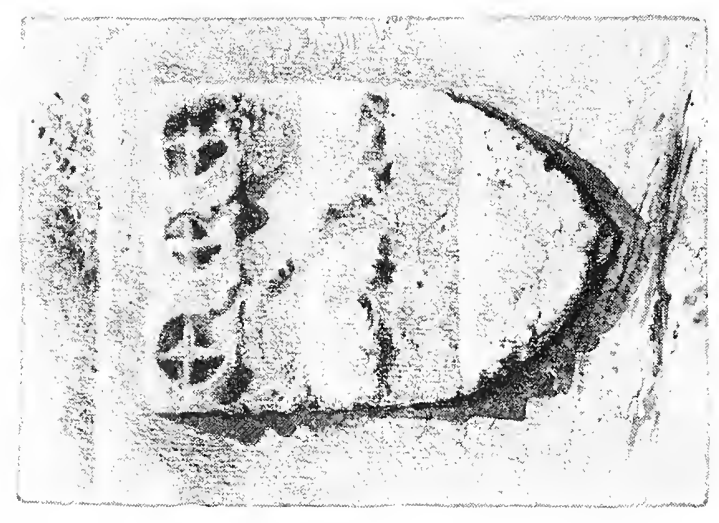

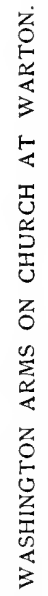


We know, then, by a coat of arms that the early Washingtons were agriculturists, honored for purity of character and for courage ; also that one of them was a belted knight. But now we take another step. The shield of this family afterwards bears, according to the old Dodsworth MS. in the Bodleian Library - "Gules on a fesse sable 3 mullets." The fesse, as we have seen, is a military belt; that it is sable means "wisdom, constancy, and also affliction." But the significant modification is the change of the three agricultural cinquefoils into three mullets or stars. The star, says Kent, "signifies Honour, or that the first Bearer had studied Divinity or such things as made him shine in virtue or learning." But it also has another significance. "The star derives its name (saith Vossius) from the Saxon word steoran, to stear a course ; and rightly enough, seeing it is by the Stars that the Ship is guided in her way. Hence it is that the Bearing of them in Heraldry is used to signify some excellency of Gifts in the Owner of the Arms, and particularly to denote great Discoveries in the art of Navigation." The next modification in the Washington arms is the substitution of two bars for the fesse. These "barres," 
says Kent, indicate that their first bearer had built a fortification for his prince.

It is in this last form that the Washington arms have remained to this day,-that is, through five hundred years. In that time every symbol on their shield has been justified. The English Washingtons have been preëminent cultivators of land and eminent divines. The last of George Washington's English ancestors - his great-great-grandfather - was a famous university preacher at Oxford. Of the nine chief representatives of the same family and name in England today, five are clergymen of the Church of England. As for steering by the stars, the Washingtons were for some centuries navigators, and early traces of the family are found in the Barbadoes, Bermudas, East Indies, and the port of New-York. A John Washington was in the Barbadoes in 1655 , and there is little doubt that he was the great-grandfather of the General. He returned in that year to England, administered the will of his mother, and four years later is found in Virginia.

It may be interesting to give here some account of the Barons Washington of Germany. In I 799 a young officer of that family 
applied to General Washington for some position in the United States army, when war with France was imminent. In 1890 I applied, through Sir Lyon Playfair, to Baron Karl Washington, of Munich, the present representative of these German Washingtons, for the correspondence between his father and General Washington, and for some particulars concerning the family. I received from him an interesting reply (in German), with a copy of Washington's letter.

"I enclose a copy of our coat of arms, painted by my nephew Baron Stefan Washington, LL.D., copied with exactness from our patent of nobility, which will completely acquaint you with the same. Concerning our motto, Exitus acta probat, I can only tell you that it is in the patent, dated December I 2, 1829, where it is said that the Coat of Arms remains the same, with the addition only of the Baronial coronet [five-pointed]. So our family must have had the motto before my late father was raised to the Bavarian nobility (created Frei Herr) at the date stated. George Washington's letter was wrapped in a special sheet of paper, the address written by himself. His seal shows a difference 
from ours in the crest, which my nephew has carefully indicated in his drawing. Beneath the seal of Washington are written the words Exitus acta probat, but not by his hand; it resembles my father's writing, but I cannot be positive that he wrote it. Mr. Henry Horstmann, the United States Consul at Munich, formerly had the kindness to write to his government on this matter, and through him I received many interesting particulars of the family of General Washington, but none that would demonstrate our descent from the same family. In the old family Bible, now belonging to Mr. Keurenaer, at The Hague, I find nothing concerning the time when James Washington left England, except a note of my father's writing in which he mentions the year as I682. My father died in 1848. My half brother, still living, was then a Lieutenant of Cavalry. I was then in my fifteenth year, and my brother nineteen. My brother married a Duchess of Oldenburg in 1855 , and is a widower since March 20 of this year [1891]. He has two sons, George and Stefan. The first married in 1883. My brother settled after his marriage in Austria, where he has a country-seat. In my i7th year I entered the Bavarian Cavalry, and commanded a squadron in the war of 1866 , 
when I was so severely wounded, in a cavalry attack, that I was forced to leave the service, - with the rank of Lieutenant-Colonel [Oberstlieutenant]. If there is anything else you would wish to know, I would be very glad to communicate to you whatever may be within my knowledge."

The letter of Washington to the late Baron is dated, "Mount Vernon (in Virginia) 2oth of January I799":

\section{"Sir -}

"Through the goodness of Mr. Adams, the American Minister at Berlin, I am indebted for the safe conveyance of your letter, dated the 19th of October, in that city; and through the same medium I have the honor to present this acknowledgment of it.

"There can be but little doubt, Sir, of our descending from the same stock, as the branches of it proceeded from the same country. At what time your ancestors left England is not mentioned. Mine came to America nearly one hundred and fifty years ago.

"The regular course of application for military appointments is to the President of the United States through the Secretary of War. But it would be deceptious not to apprise 
you beforehand that it does not accord with the policy of this Government to bestow offices - civil or military - upon foreigners, to the exclusion of our own citizens. First, because there is an animated zeal in the latter to serve their country; and secondly, because the former, seldom content with the rank they sustained in the service of their own country, look for higher appointments in this, which, when bestowed, unless there is obvious cause to justify the measure, is pregnant with discontent, and therefore is not often practiced, except in those branches of the military service which relate to engineering and gunnery; for in these our military establishment is defective, and men of known and acknowledged abilities, with ample testimonials thereof, would be certainly encouraged.

"Deeming it better to give this candid detail than to raise hopes that might prove fallacious, is the best apology I can offer for my plaindealing. At the same time, be pleased to accept assurances of my being, Sir, your most obedient and very humble servant,

"Mr. James Washington."

"G. Washington. 
The entry in the old family Bible at The Hague is as follows: "James Washington left England about the middle of the seventeenth century, when the country was disturbed by civil wars; he came to Holland and settled at Rotterdam. His brother went to the English colonies in America, settled there as planter, and was the great-grandfather of the founder of the American Union-George Washington." To this Baron James Washington has added the date 1682 .

There is little doubt that James Washington, the first Baron, was more nearly correct in fixing the date of his ancestor's departure from England than the Bible at The Hague. For there was one Joseph Washington, Gent., of the Middle Temple, London, who in his will (probate 7 th April, 1694) mentions a "brother James, of Rotterdam, merchant." This Joseph was a son of Robert Washington, of Leeds, England, and was born there; but his father was born at Adwick-le-Street, Yorkshire, and Joseph's will disposes of lands in the latter place. The German family tradition is that James escaped to Holland because he was involved in the Monmouth affair. This would assign 1683, the year of the Rye House plot. The discovery of the Washington pedi- 
gree by Mr. Waters, as well as the date of Joseph's birth, proves the tradition that the founder of the German family was a brother of Col. John of Virginia erroneous. Nevertheless, there was a migration of Yorkshire Washingtons to Virginia before and after that of Col. John, Washington's great-grandfather; and among them was one named John, who settled in Surrey County, Virginia, where he married Mary Flood, to whom he was betrothed in 1658 , - the year before the General's ancestor arrived.

It may be noticed that the shield of the German Washingtons is supported by griffins; and one of the crests used by the General in Virginia was a griffin. It was used by his uncle, Major John Washington, as early as 1736, although his English ancestors used the raven. It is possible that Col. John Washington's first wife was one of the Yorkshire Washingtons, or from some branch of theirs in Cumberland or Westmoreland, England.

Let me conclude this heraldic chapter by calling attention to the poetic fact that George Washington, in whom the fame of his race culminated, fulfilled in one way or another every suggestion of the family arms. If there is any exception, it must be found in the in- 
terpretation of the shield's stars as indicating the profession of divinity. That he was not knighted was due solely to his espousing the cause of the Revolution. Edmund Randolph, grandson of Sir John, declares that Washington's name had already been enrolled for royal honor. That George Washington did not become a navigator was due to his mother, who canceled his commission. And finally the agricultural cinquefoils of the earliest Washington shield, unknown for five centuries, and first made known in these pages, returned in a sense to the shield of George Washington. It was he who modified the shield into a sort of cornucopia, and surrounded it with foliations of wheat and other emblems of the farm, - a final attestation that, whatever coats others might purchase or wear, with Washington the Arms still meant the Man.

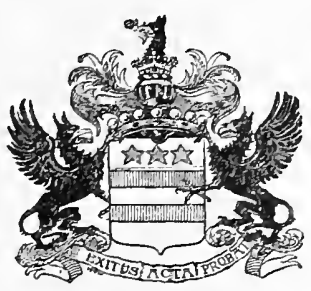




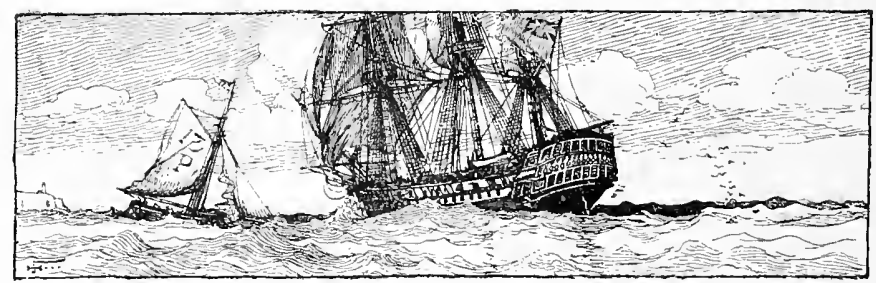

IV

Augustine Washington and bis Family

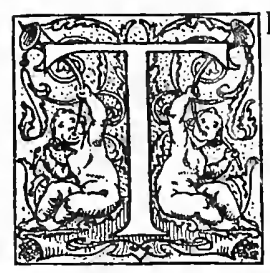

Washington family has passed into a conventionalization curiously resembling that of the Holy Family: the savior of his country has for his mother a saintly Mary; his father is kept in the background like Joseph; he is born in a mean abode. The actual facts, if less pious, are more picturesque. General Washington himself describes his birthplace as a "mansion," and we shall see that it was an extensive one; his mother, with whatever striking qualities, was no saint; and evidence can now be produced to show, in the Gen- 
eral's historically neglected father, a strong and scholarly man whose life was one of notable adventures.

Augustine Washington was born in Westmoreland, Virginia, in 1694. On the death of his father, Lawrence, in March, 1698, his mother (née Mildred Warner) went with her three children-John, Augustine, and Mildred - to England. The Warners and Washingtons had been related to each other in England as early as the sixteenth century, as is shown by a brief will which I copied in Somerset House, London (Cobham, 3I, P. C. C.):

"Will of Walter Washington, of Radway in the parish of Bishop's Ithington, in the Countie of Warwicke, Gent. Being asked by his uncle, George Warner, to whom he willed his goods, he answered that he gave all he had to his wife and children. Witnesses: Richard Hill, George Warner, John Murdon, Catharine Murdon, Dorothea Caunt, Wodnefrode Browne. April 23, 1597. Admon. issued to his widow Alicie Washington."

This Walter Washington was the greatgreat-granduncle of Augustine Washington. 
His descendants, and probably some of the Warners, continued lcng in Warwickshire, and the widow of Lawrence may have taken her children there. We first find her, however, in Whitehaven, Cumberland County, England, married to a second husband, George Gale. In that town there was a family of Washingtons, though their connection with the Virginians has not yet been made out. In the parish register of St. Nicholas Church, Whitehaven, appears the baptism, January 25, 1700-1, of Mildred, daughter of George Gale; the mother was buried January 30, and the infant March 26, of the same year. In the will of Mildred Gale, dated January 24, proved March I8, 1700-1, she says: "By an Indenture of Marriage made and executed by and between John Washington one of the executors of my late husband's Will of the one part, and my present husband George Gale with my own consent and approbation thereof of the other part, bearing date 16 May in the present year 1700 I am empowered to demise by Will or other instrument the estate and legacy of my late husband to the use and purposes therein mentioned." She bequeaths to her husband $£ 1000$, and divides the residue of her 
property equally between him and her children. The John Washington mentioned was the son of Lawrence, the younger immigrant, who had a sister in England, and may have been on a visit to her when the marriage settlements were made between the widow and George Gale. Or it may be that the settlements and the marriage took place in Virginia. When George Gale took probate of his wife's will, he gave bond for the education of her children, John, Augustine, and Mildred. There was a famous grammar-school at Appleby, in the neighborhood of Whitehaven, and to that the boys (John, b. 1690, Augustine, b. 1694) were sent. About the year 1712 George Gale removed to Maryland, but whether the brothers John and Augustine returned with him does not appear.

John married Katharine Whiting, of Gloucester County, Virginia, where he settled, apparently at a place called "High Gate," on the Pianketank River, in Petsworth parish, of which he was a vestryman. He bore the title of major, but lived a quiet life. A letter of his exists, dated July 12, 1744, to Cary \& Co., London, ordering a tombstone, no doubt that of his wife, still seen at High Gate: 
"Underneath this stone lyeth interred the body of Mrs. Katharine Washington, wife of Major John Washington, and daughter of Col. Henry Whiting by Elizabeth his wife, born May 22, 1694. She was in her several stations a loving and obedient wife, a tender and indulgent mother, a kind and considerate mistress, and above all an exemplary Christian. She departed this life February 7, 1743, aged 49 years, to the great grief of all that had the happiness of her acquaintance."

On this tomb is the design of an urn with four mastiff heads, and surrounded with foliage. Near it is a tomb with the following inscription :

"In a well grounded certainty of an immortal resurrection, here lie the remains of Elizabeth, the daughter of John and Katharine Washington. She was a maiden virtuous without reservedness, wise without affectation, beautiful without knowing it. She left this life on the 3rd day of February 1736, in the twentieth year of her age."

The design on this tomb is a foliated urn, with three stars on it, and a griffin's head 
above. This is the first instance I can find of the use of the griffin by any Washington. The crest of the English families was a raven, or sometimes an eagle, and the griffin as a seal first appears unmistakably on letters of George Washington. Mrs. Mary S. Payne of Kentucky, to whom I am indebted for notes concerning her Lewis ancestors, thinks the griffin on this urn probably that of the Lewis crest, the first wife of Colonel Fielding Lewis having been a daughter (Katharine) of Major Washington; but in that case the griffin would have had the bloody hand in its mouth, the especial characteristic of the Lewis crest.

One of Major Washington's sons, Warner, married Hannah, daughter of William Fairfax; another, Henry, married a Thacker. It appears by a letter first printed in this book that Major Washington died September 1, 1746. His sister Mildred (b. 1696) married Roger Gregory, of Stafford County, Virginia. She was George Washington's godmother. The Gregorys had three daughters who married the brothers Thornton, of Spottsylvania, becoming the ancestors of General Woodford of the Revolution, Judge Harry Innes, Senator Beck, and other eminent men. About 1733 Mildred 
Gregory married, 2d, Colonel Henry Willis, the founder of Fredericksburg. It is said that Colonel Willis vainly courted three maidens in youth, all of whom he married as widows. His second wife, the widow Brown (née Washington), was also named Mildred; she was George Washington's grandaunt. She was, by her first husband, ancestor of some of the Lees and Crittendens of Kentucky; while from her union with Colonel Willis sprang branches of the Willis and Minor and Taylor families of Virginia, and of the Greens, Barbours, and Marshalls of Kentucky. A grandson of Colonel Henry Willis, namely Colonel Byrd Willis, married a granddaughter of Colonel Fielding and Betty (Washington) Lewis, and one of his (Colonel Byrd Willis's) daughters married Prince Achille Murat, and figured at court in Paris.

We now pass to Augustine, the father of George Washington. On coming of age, he married (April 20,1715) Jane, daughter of Caleb Butler, an eminent lawyer of Westmoreland, the "trusty and well-beloved friend" to whom Ann (Pope), the widow of - Colonel John Washington, had given power of attorney. Augustine purchased of John, his elder brother, the old family mansion, "Wake- 
field," - so called, at what time is not known, probably from some association in the family traditions with the Yorkshire town. By Jane Butler, his first wife, Augustine had four children,- Butler, d. infant; Jane, d. I735; Major Lawrence of Mount Vernon, b. I7 8 ; Augustine (called Austin), b. 1720.

In I725 Augustine is mentioned as "Captain Washington"; he at one time certainly commanded a ship, and it is probable that it began with his carrying iron to England and returning with convict laborers. The Principio Iron Company (English), after some years' successful work on the Patapsco, Maryland, had in 1724, if not earlier, negotiated with "Captain Augustine Washington" for the opening of a furnace at Accokeek, his estate in Stafford County, Virginia. In the Pennsylvania Magazine of History and Biography (April, July, and October, I887), Mr. Henry Whitely has published interesting researches concerning the Principio Company. A letter from John England, a practical iron-master in charge of the works, to the company in England, dated January 5, I 725, has the following concerning the Accokeek furnace and Captain Washington: "As to ye dividing ye shares of ye new founded works in Virginia, have advised with 
a Counselor about it . . . who tells me yt except some person here is appointed yr lawfull atturney, by a power of atturney from you to signe for you here, $y t$ if your deed or deeds come over for you to signe in England and either of you should dy before, or alter your minds yt you dont sign, then it setts Washington at liberty, and all ye work is at an end ... If you see fitt to make Capt Washington a small present of wine (along ye Virginia Cargo) and to signifie to him yt what I have done with him on yr behalfe you like and approve on, or to that effect, yt I leave to your Consideration either to do it or not." This seems to show that Captain Washington had himself conveyed to England the Virginia cargo, probably the first. The practical work at the Accokeek furnace was superintended by a founder of Principio, Captain Washington's contract being to cart the ore from the mines to the furnace, two miles, at the rate of $20 s$. per ton of pig-iron, and, after it was cast, to cart it to a landing on the Potomac, six miles. This was done by the captain's workmen and oxen ("three hundred weight being a load for a cart drawn by eight oxen"). The increasing business was probably one reason for the Captain's going to England 
himself, as he could bring back laborers. England was then anxious to send convicts, especially political offenders, to the colonies, and Virginia was giving grants of land for their importation. Record exists of one such voyage and importation of convicts by Captain Washington, and there is also evidence of his personal intimacy with gentlemen in England.

The wife of Captain Augustine Washington died in 1728 , - her gravestone is at "Wakefield," - and on March 6, 1730-1, he married Mary Ball. She was the daughter of Colonel Joseph Ball (whose homestead was "Epping Forest," Lancaster County, near the mouth of the Rappahannock) by his second wife, the widow Johnson. Mrs. Ella Bassett Washington (Century, April, 1892) says: "That the bride was blonde and beautiful both history and tradition tell, and of the bridegroom in his fortieth year a description has been transmitted from one generation to another. Mary Washington's description of her husband is confirmed by the testimony of contemporaries - a noble-looking man, of distinguished bearing, tall and athletic, with fair, florid complexion, brown hair, and fine gray eyes." Although the word "history" 
can hardly be used with exactness in such descriptions, - there being no verifiable documents concerning the personal appearance of George Washington's parents, - the family traditions, as reported by one of its members, are of some interest.

The Rev. C. C. Colton, an English author, states that Captain Washington first met his bride in England. He was thrown out of a carriage and into the company of a lady who emigrated with him to Virginia. The incident is said to have occurred in Cheshire (Lacon, ii., p. 112). The clergyman's story has been discredited because Lossing connected it with the notion that George Washington was born in England, in disregard of the General's own statement and the record of his Virginian godfathers and godmother. It now appears, however, by the facts revealed in this book, that Colton knew what he was writing about. When Col. Joseph Ball died, in 1711, his widow, who was an Englishwoman, disappears with her two children - Eliza Johnson (child of her first husband) and Mary Ball from the records and registers of Virginia. Forty years later Colonel Ball's son purchased relics of Virginia Balls from a Mrs. Johnson in England. (Hayden.) Mary Ball isfirst traceable 
in Virginia as Mary Washington, and her letters to her half-brother in London show intimacy with his wife, who seems to have never been in America. Now that we have letters showing Captain Washington's friendships in England, along with the other facts, there is no reason for discrediting the clergyman's statement that he there first met Mary Ball.

Captain Washington brought his young wife to his home on the Potomac, "Wakefield." In describing that house as a small one, popular writers have followed each other like a flock of sheep; but even a flock of sheep, grazing over the debris of "Wakefield," might discover, at least to an observing eye, that it was a large mansion. A little digging reveals massive brick foundations, and all the features of the ground indicate a noble residence. The site of the large flowergarden is traceable by certain outlines, and also by descendants of the flowers once cultivated there. There are remains of a large brick-walled dairy, built underground. However, the usual description of "Wakefield" as little more than a hovel, is now proved fictitious by the recently discovered inventory of its contents. 
This inventory (in the Havemeyer collection) was made on the decease of Austin (1762), to whom his father had bequeathed it. There is furniture for eight bedrooms, and much for other rooms.

Here a chorus will cry that the original house had been burned. Has not Lossing given all the details of the fire? Nevertheless, the fire did not occur until the Christmas Eve of 1779. But may not Austin have enlarged the house? Possibly; but there is no evidence of any alteration. General Washington wrote to Sir lsaac Heard that his brother Austin occupied "the ancient mansion seat" until his death. And why should not "Wakefield" have been a grand place? Captain Augustine Washington's father, Lawrence, divided between his three children nearly five thousand acres and much personal property; and both of the Captain's wives possessed substantial estates.

Here, then, Washington was born. There exists a note of Captain Augustine, written in 1733 to Mr. Jeffries, saying that he and his wife will make him (Jeffries) a visit on their way to Moratico, a homestead of the Balls on the lower Rappahannock. He says they will bring with them their "baby George." The 
substance of this note has been repeated to me by Mr. Lawrence Washington, of Alexandria, who had read it. This is probably the earliest allusion to George Washington; for the entry of his birth and baptism, in the family Bible, is of such exceptional character as to suggest insertion at a later time.

In 1734 the neighborhood in Westmoreland was enlivened by the settlement there of the new agent of Lord Fairfax, namely, William Fairfax, who brought with him an accomplished wife (née Deborah Clarke, of Salem, Massachusetts) and family. A warm friendship was formed between these families. William Fairfax had an aunt in Yorkshire, England, who had married a Washington. Whether Lawrence Washington met his future wife, Ann Fairfax, before his departure for school in England is uncertain.

Towards the close of 1734 , or early in 1735 , Captain Washington came to the conclusion that "Wakefield" did not agree with the health of his children (there were then four with him), and removed to his estate on the upper Potomack,- then known by its Indian name, Epsewasson, now Mount Vernon. Although the latter name was not given until some years later, the place will be spoken of 
in these pages as Mount Vernon. The estate had been Colonel John Washington's moiety of 5000 acres, given him and Colonel Nicholas Spencer for importing one hundred laborers into the colony. Colonel John's son Lawrence possessed near its boundary a mill and, probably near this, a house, wherein dwelt at the time of his death Mrs. Minton and Mrs. Williams. The estate was bequeathed to the Captain's sister Mildred (Gregory), of whom he had bought it (May, 1726) for $£ 180$. With Mount Vernon, therefore, were associated the earliest memories of George and Betty Washington, and there the younger children were born.

The first to discover the error of biographers in stating that the Washingtons moved from "Wakefield" to the farm near Fredericksburg was the Rev. Dr. Philip Slaughter, historiographer of the diocese of Virginia; though the true facts do not appear in any of his works, being found after his days as an author were past. Alas! how do I mourn that I cannot compensate that venerable friend for the information entrusted to me by hastening to gladden his heart with the revelations of these newly discovered letters ! I cannot forbear introducing here some brief 
tribute to our old master in Virginia lore, by whose death (June 12, 1890) all historical students are bereaved indeed. Dr. Slaughter (born October 26, 1808, in Culpeper County) was not only the author of the historical and biographical monographs bearing his name, but contributed something to most of the work of that kind done in Virginia during his time, including the important volumes of his friend, Bishop Meade. A thorough and exact investigator, caring little for his own fame as a discoverer, but much for the truth of history, he was consulted by historical writers long before his appointment (1879) as historiographer, and freely distributed his stores of information, asking neither credit or return. He was honored by his fellow-students in the University of Virginia, where he graduated in 1825 , and was commissioned by them to invite Lafayette to a reception. He told me of the emotion with which he met that famous man and also three ex-presidents at Monticello,--Jefferson, Madison, and Monroe. Dr. Slaughter began his career as a lawyer, but after five years of prosperous practice left the bar for the pulpit. His sympathies were deeply stirred for the slave, and he was one of the first to throw himself into 
the cause of African colonization. In 1850 he founded and edited in Richmond the Virginia Colonizationist. In 1856 he established himself in Culpeper County, Cedar Mountain, where he built a church at his own expense, and preached without remuneration, ministering with especial care to the negroes. His church was destroyed in the terrible battle of Cedar Mountain, and his invaluable library, containing precious manuscripts accumulated through many years, pillaged, torn, scattered by the contending armies. When he returned to his home, he found bits of his treasured papers strewn about the grounds. He told me that a friend, visiting Philadelphia, remarked on a centre-table there one of his valuable books, containing his book-mark. He never applied for it, and in narrating these things the great-hearted clergyman uttered no murmur. When I visited him at Cedar Mountain in the year before his death, he appeared to me a sort of avatar of the old Virginian race, whose annals he had so largely recovered and preserved. His ancestors and those of his wife (née Semmes, of Alexandria) had lived in the same region for two hundred and fifty years before them. They had inherited traditions so vivid that the scholar 
talked of the Spotswoods, Washingtons, and other worthies as if they were old friends. His mind was clear, his memory exact, his heart full of sunshine, as if he were still in life's morning instead of his eightieth year. With his wife and children around him, in his pretty home, commanding a beautiful landscape, honored by his State, beloved by all who knew him, with a life of long and faithful services to humanity and to literature to look back on, the historiographer remains in my memory as an almost ideal figure. Although he had suffered many losses, he had nothing to grieve for except that he was unable to publish to the world the results of his later investigations; and these he carefully made known to me, in words and by letters. As 1 was last parting from him, he said, "Since the recent discovery of the ancient Truro Vestry-book and Manuscript, containing so much of interest concerning the Washingtons and others, I have longed for a new lease of strength to edit and publish it. Can you not find in the North some wealthy gentlemen who will provide the means for publishing this most important document? A page containing autographs of the vestrymen - Washington, George Mason, and others - 
has been carried off and is now in the NewYork Historical Society, and some few parts are missing or damaged, but the substantial historical value of the manuscripts is not impaired. I must leave these things to younger men. I feel a great satisfaction in delivering to you all the information I possess. It is a relief to know that if it be of any worth it will not die with me."

Dr. Slaughter's later and unpublished researches, so far as they bear upon the Washington family, I am happily able to present in his own words. The letter was not intended for publication, but is one of several written for use in connection with investigations of my own. The "convict story," to which the letter refers, is that of the Rev. Jonathan Boucher, George Washington's early friend (teacher of young Custis, his wife's son), who wrote that he (Washington) "was taught by a convict servant whom his father bought for a school-master."

"Dear Mr. Conway :

"July 24, I 889 .

"I was on the eve of writing to communicate an item to your 'convict story,' but was waiting for an answer to some queries put to you some weeks ago about Acquia Church 
- which may have miscarried. The following facts are authenticated by the Records, and have a bearing upon your inquiry. I set them down as they occur to me, and your analytical mind can reduce them to order and draw the true conclusions, for which I have not time just now, being surrounded by company, and under pressure of the Press, calling for copy, etc.

"In 1730 Prince William County was formed from Stafford and King George, and extended from Chapawamsic Creek and Deep Run along the Potomac to the Blue Ridge. In 1732 Truro Parish was instituted, comprehending all of Prince William above Occoquan and Bull Run, and north of Ashby's Gap. Augustine and Lawrence Washington, father and son, represented it in the House of Burgesses (exact date not remembered). On the i8th of November, i735, Augustine Washington was sworn as vestryman of Truro Parish, and also signed the Minutes in August, 1736. He recommended Charles Green as candidate for orders to the Bishop of London. He went to England, and returned in July, 1737, in a ship from London to Potomac, 'witb convicts.' A fellow passenger, Captain Hugh French, died of 'gaol distemper con- 
tracted on board ' - Captain Washington was reported in 'good health.' He was present at a Vestry 13th of August, I737, and Charles Green was elected as Rector of Truro Parish. To be a Vestryman one must be a Parishioner. He was present at the Vestry October, 1737. There is a gap in the Vestry Book from this date to October, 1739 , and his name does not again appear.

"Augustine Washington, in 1740, conveyed to Lawrence [his son] 2500 acres. This deed was recorded in the General Court Office, October 23, 1740 (burned in the late war). The Will of Augustine Washington confirming this deed was recorded in King George County, May I743. The Will of Lawrence Washington devised [the reversion of] these

- 2500 acres to George Washington in 1751 (Mount Vernon). The probable inference from these facts is that he [Augustine Washington] lived at Mount Vernon until I739, and moved to King George where his Will was recorded. Augustine Washington died 12 April 1743. I doubt that the Deep Run residence is probable. Truro Parish and King George answer all requirements.

"I tried fully to identify the convict Sexton with our 'Hobby,' but the facts refuse to ac- 
commodate themselves to the theory, plausible and seductive as it may be. His name was William Grove. He was appointed by the Rector (Green) Clerk [of Truro]. But there was a division of sentiment about it, and Green appointed another man. Whereupon the friends of Grove got a mandamus to compel his acceptance; but Grove modestly declined the contest and took the post of Sexton. So our 'Hobby' will have, like one higher in office if not in morals, to 'go to his own place'- not meaning any disrespect to Falmouth or Fredericksburg.

"I shall be pleased to hear the result of Mr. Waters's researches. I have a working hypothesis founded upon the omission of a generation by Sparks, - thus missing the line of descent.

"I shall look for your Washingtoniana with much interest, and expect to derive pleasure and profit from it.

"Yours very truly,

"P. Slaughter."

Dr. Slaughter had a strong impression, which I share, that Washington was sent at first to an infant school near Falmouth, a village fifty years older than its more important 
neighbor, Fredericksburg. I was not able before his death to do more than suggest the theory to which he refers,- namely, that "Hobby" was a nickname of the convict declared by the Rev. Jonathan Boucher to have been purchased by Captain Washington as a schoolmaster, and to have taught George. Also, that this teacher was that same convict whom the Truro rector, who owed his place to Captain Washington, tried to make clerk and did make sexton. This occurred immediately after Captain Washington came in with his ship full of convicts, in 1737 . When he removed to the neighborhood of Fredericksburg, I739-40, he would naturally take this educated, and probably political, convict with him, and may have got him a place as sexton at Falmouth. Parson McGuire, a connection of the family, states that "Hobby" was "at once a teacher and sexton." Grove was certainly both in Truro, and possibly on the Rappahannock, - this being before the Fredericksburg school to which the Washington children afterward went was fairly opened, and when they were too small to be trusted to the ferry.

One of our letters renders it probable that the removal of Captain Washington to the 
neighborhood of Fredericksburg, in 1739-40, was due to the burning of his house at Mount Vernon. No doubt this was the fire which Custis, Lossing, and others have confused with that which destroyed "Wakefield" forty years later.

Tradition has hitherto said that Lawrence Washington was educated at Oxford. Had that been true, his name would have been found there; and now that his attendance at the Appleby School is proved, the tradition may be dismissed until some verification has appeared. The year of his entrance in the school has not yet been discovered, although it will probably be found by the gentlemen at Appleby, whom our new-found letters have interested. Lawrence returned, probably, in I738, and certainly full of loyal enthusiasm for England and Vernon, and of rage against the cisatlantic Spanish. The governor of Virginia was now William - presently Sir William - Gooch, who had won some fame in Queen Anne's wars, and was rather popular in the colony. He was in 1740 brigadier-general in the British army, and colonel of the Virginia regiment in which Lawrence, aged twenty-two, was given the commission of captain. The disasters which the British 
forces under Admiral Vernon met at Cartagena are recorded in every history and encyclopedia, so that the reader need not be detained by them here, though it may be found interesting to compare with the conventionalized accounts some passages in the letters to Major Lawrence printed in this volume. For the present chapter I select, however, a letter written to Captain Augustine Washington. This, which is the only letter I have seen written to General Washington's father, is from Richard Yates, master of the Appleby Grammar School, in which his eldest sons had been educated.

"To Augustine Washington, Esq.

"Dear Sir,

"Appleby, Oct. 9, I741.

"In the midst of your late calamity wch. you suffer'd by fire, for which I am sincerely concern'd, there's a more sensible pleasure to find room for congratulation: and I do most heartily give you joy of your son's happy escape out of ye midst of a danger yt prov'd fatal to so many about him, and I pray God he may live long to enjoy ye satisfaction and benefit of his advancement in ye army as well as to give a comfort to his father. 
"Mr. Deane (whose intentions and conduct are and always have been so friendly to you and your sons) will say enough to you about your son Austin's desire to study ye Law, so $\mathrm{y}^{\mathrm{t}} \mathrm{He}$ will spare me ye trouble of saying more than $\mathrm{yt}^{\mathrm{t}}$, if you think it convenient for him to be educated that way, I believe he will take abundance of pains to shine in a profession on which he has set his heart. Not but that I have that opinion of ye Lad's goodness $y t$ if he thought it were not agreeable to your sentiments he $\mathrm{w}^{\mathrm{d}}$ reconcile his thoughts to any other employment you shd think most expedient for him.

"I am, with my best respects to Major Washington,

"Dear Sir,

"Your most affectionate Friend, and Very Humble Servant, "RI: YATES."

This letter is not addressed to any particular place, probably because the writer did not know just where the captain had settled down. Every ship captain would know how to convey the letter. It is endorsed by a word not easily made out, but which 1 believe meant for "forwarded." The reader 
will observe the indications in this letter that Captain Augustine Washington and his brother John, the "Major Washington" of Yates's letter, were personally acquainted with these gentlemen at Appleby.

It has been stated by some writers that Major Lawrence Washington built the mansion-house at Mount Vernon. But this does not appear to be the fact. After the burning of his house near the mill (if that was the locality), Captain Washington seems to have built another house, and furnished it for his son, perhaps with some hope of a marriage between Lawrence and the daughter of his friend Hon. William Fairfax. Lawrence, as eldest son, would naturally have inherited the family seat in Westmoreland, but preferred Mount Vernon, perhaps because of its proximity to Belvoir, the home of the Fairfaxes. In the will of Captain Augustine it is shown that Lawrence was then (April 11, I743) residing in a house given him by his father. The estate is bequeathed, "and all the slaves, Cattle and Stocks of all kinds whatsoever, and all the household Furniture whatsoever now in and upon or which have been commonly possessed by my said son together with the said Tract of Land and Mill." The captain 
died April 12, 1743. In July of the same year Lawrence was residing in the new mansion, being certainly there before his marriage on the r 9 th of that month. As he was in the West Indies from 1740 to the latter part of 1742, we may suppose that the mansion was mainly built in his absence, and no doubt it was erected by his father as a gift.

Meanwhile the family was residing on the farm across the river from Fredericksburg, - then in King George, now in Stafford County. It was originally a purchase from the Strother estate of 280 acres, on which stood a house of which A. K. Phillips, a venerable citizen of Fredericksburg, writes me that his father remembered it, in 1806 , as "a plain wooden structure of moderate size, and painted a dark red color." It long ago disappeared, and the picture in Lossing's "Mary and Martha Washington" is not authentic:

Toward the close of June, 1742, the captain's son Austin returned home from school in Appleby, England. His plan for adopting the legal profession does not appear to have found favor, or possibly the father's failing strength did not admit of its being fully considered, for we presently find Austin married (to Ann Aylett) and settled at "Wakefield." 
Captain Augustine Washington appears to have been the only American who entered very actively into the iron enterprise. The Principio Company was divided into twelve shares, of which he owned one, the rest being owned by Englishmen. His farm on the Rappahannock was not far from the Accokeek works, and his enterprise was such that they were left at his death the most valuable in the country. "In 1750," says Whitely, "it [Accokeek] sent to the company in England four hundred and ten tons of pig-iron,about one-fifth the entire quantity exported from Maryland and Virginia for the year."

Near the close of the captain's life a question arose between him and his brother John concerning the boundary between the estates bequeathed them by their father in Westmoreland. The brothers agreed to submit the matter to Daniel McCarty and Richard Bernard, entering into bonds of $£ 1000$ each to abide by the decision of the referees. The original papers and drawings are here, but cannot now be comprehended without entering into uninteresting details. The decision, duly signed and sealed by the brothers, was admitted to record in Westmoreland, April 12, 1743, - the day on which Captain Au- 
gustine Washington died at his house near Fredericksburg.

Captain Washington caught his death in the same way that his son, the general, did at the end of the century. He was overtaken by a storm while riding, caught cold, and died of some acute complications. The Rev. Dr. Edward C. McGuire (who married a granddaughter of Betty [Washington] Lewis, and was forty-five years rector of St. George's Church) published a little book on "The Religious Opinions and Character of Washington" (1836), in which one occasionally meets with details evidently obtained by personal investigation. Dr. McGuire's work proves that at the time it was written there was no tradition in the family of any fire at Wakefield, removal from which was caused, he says, by its unhealthiness. Concerning the death of Captain Washington, his account may be depended on.

"Between him [George Washington] and his father, it would seem that a delightful intercourse always subsisted; it being a matter of regret to the latter that he was obliged to be separated from his child even during the hours of school. Mr. Washington survived 
his removal from Westmoreland [Prince William] but a few years. He had time enough allowed him, however, to mark the budding virtues of his son. It was in the Easter holidays that Mr. Washington was taken sick. George was absent at the time, on a visit to some of his acquaintances at Chotanct, King George [then in Stafford] County. He was sent for after his father's sickness became serious, and reached the paternal abode in time to witness the last struggle and receive the parting benediction of his beloved parent."

Captain Washington left more than five thousand acres of land,- the estates being in Prince William, Westmoreland, King George, and Stafford,-also a mill near Mount Vernon. Twenty-two slaves are bequeathed, besides others, not enumerated, devised to Austin by his mother. The shares in ironworks in Maryland and Virginia are bequeathed to Lawrence. George is left the farm near Fredericksburg, two lots in that town, some land at Deep Run (quantity not specified, probably small), and the reversion of Mount Vernon, in case Lawrence should die without heir. Betty receives two young female slaves, and four hundred pounds ster- 
ling, when she is eighteen, to be paid by Lawrence out of the iron-works, - a very substantial bequest at the time.

The captain's will is the first of his line that omits a profession of Christian faith. It opens with the words "In the name of God, Amen," this being also the only religious expression in the wills of his sons, so far as they have been made public. Mrs. Throckmorton, daughter of Warner Washington by his wife Hannah (Fairfax), told M. Bayard that Captain Washington was a deist. He reports in his book of travels: "Elle me dit qu'elle le croyait de bonne foi qu'à la mort du père de Washington, qui était un déiste, le fils devint très religieux." Freethinker though he was, Captain Washington was active in parish affairs. Dr. Slaughter once told me that he thought modern critics were making a mistake in entirely discrediting Parson Weems's "Life of Washington" entirely because of some fanciful stories, like that of the cherry-tree. For several of the anecdotes he believed there was some basis, though the parson's passion for embellishment naturally excited distrust. I am inclined to think that there may have been some basis for the following anecdote, though the parson, or the 
lady who related it to him, has turned it into a pious allegory, and pointed it with a moral that no deist could believe.

"On a fine morning in the fall of $1737 \mathrm{Mr}$. Washington, having George by the hand, came to the door and asked Cousin Washington [his wife] and myself [the lady who tells Weems the story] to walk with him to the orchard, promising to show us a fine sight. On arriving at the orchard we were presented with a fine sight indeed. The whole earth, as far as we could see, was strewed with fruit; and yet the trees were bending under the weight of apples. 'Now, George,' said his father, 'look here, my son! Don't you remember, when this good cousin of yours brought you that fine, large apple last spring, how hardly I could prevail on you to divide with your brothers and sister, though I promised that if you would but do it, the Almighty would give you a plenty of apples this fall ?' Poor George could not say a word; but, hanging down his head, looked quite confused. 'Now look up, my son,' continued his father, 'and see how richly the Almighty has made good my promise to you!' George looked, in silence, on the wide wilder- 
ness of fruit; then, lifting his eyes to his father, he said, with emotion, 'Well, pa, only forgive me this time, and see if I am ever so stingy any more.'"

The "venerable lady" who related this has probably, by a familiar fallacy of memory, disguised in her own pietism some casual reproof of selfishness illustrated by the orchard's generosity; but this legend of the captain's affectionate care for his son's moral nature is valuable. That he was very careful about the education of his children is proved by his sending Lawrence and Augustine to Appleby Grammar School in England, where he had himself been educated. Concerning this revelation of our letters, I have consulted the Rev. Canon Mathews, Vicar of St. Lawrence, Appleby, and have from him the following important communication :

"Since I wrote to you I have had the opportunity of consulting an elderly clergyman, a native of Appleby, whose father was for many years the classical Master at Appleby Grammar School. He informs me that he can recollect when he was a boy a search being made into the connection of the Wash- 
ington family; and his father ascertained beyond a doubt that General Washington's father, and probably his grandfather, certainly several members of the family, were educated at Appleby Grammar School. My informant's father, whose memory went back well into last century, was also a native of the very locality from which the Washingtons sprang. They lived for some generations on the borders of Yorkshire and Westmoreland [England], now in one county, now in the other; - in the valley of Ravenstonedale in Westmoreland, or in the parish of Sedbergh in Yorkshire. Part of the boundary between these parishes - which is here the boundary also between the counties - is known by the name of Wasbingbam in old parish records, and it is believed that the name arose from this. My informant says he believes that, in common with a large proportion of the inhabitants of that secluded district, the ancestors of the Washingtons were originally Flemings, who were driven out from the Low Countries in the persecutions of Alva. They were strongly Protestant, and settled in these mountain regions partly for the sake of the water power which was useful in their trade of weaving, which 
they brought with them and followed largely. The Washingtons here were for some time White-smiths."

While the present chapter contains, as I believe, the only investigation ever made into the character and career of Washington's father, his mother has been a favorite theme, especially, one must add, of fiction. Pious romances concerning her have so long passed for fact, that the publication of some prosaic facts concerning her has caused a reaction, and counter-romances are appearing. As I write one of these is going the rounds of the press, purporting to be the substance of a letter from General Washington to his mother, declining to receive her in his house on the ground that she was unfit to meet his guests. The letter out of which this scandalous paragraph is forged may be read in the eleventh volume of Ford's "Writings of Washington." It was written in 1787 , when his mother was eighty-one, much broken by age, and is full of filial devotion. He incloses her money, and tries to persuade her to rent the house (his property), use the money it would bring as her own, and live with one of her three children. His house, he declares, is at her ser- 
vice, but feels that he must candidly tell her that it is a kind of tavern for distinguished travelers, and that she could hardly stand the fatigue of dressing to meet company, or find there the retirement needed at her advanced age. It is sad to think that even the press sensationalist could invent such a calumny on Washington and his mother as is found in this totally baseless paragraph. It is characteristic of neither. Washington was through life a devoted son, and she a fond mother. Her three known letters are badly written and ill spelled. Her mother and the English Johnson family, among whom she was brought up, were probably illiterate. But Mary Ball was a strong and striking character, was looked upon with respect and affection by her relatives and neighbors, and brought up her large family to be influential and prosperous citizens, to say nothing of her illustrious son, who often acknowledged his debt to her.

Mary Washington's correspondence with her half-brother, Joseph Ball, a lawyer in London, shows his confidence in her intelligence and judgment. Her notes reveal pleasant relations with the family of Peter Daniel, presiding justice of Stafford County, who married 
her half-sister's daughter, and with the Ball connection on both sides of the Atlantic. In one letter to Joseph Ball in London (1759) she says, "Thear was no end to my troble while George was in the army, butt now he has given it up." In an undated letter to her son John Augustine Washington (in Bushfield, Westmoreland, Virginia), she complains of poverty. "I am a going fast, and it, the time, is hard. I am borrowing a little cornnno cornn in the cornn-house. I never lived so poore in my life. Was it not for Mr. French and your sister Lewis I should be almost starved, but I am like an old almanack out of date." This note was no doubt written about the year 1781 , when in mental decline, her children being much oppressed by the public service. There is ample proof in General Washington's accounts of his constant care for his mother. He heard of her complaints, and wrote to his brother, John Augustine Washington, requesting him to find out whether his mother's troubles were real or imaginary, authorizing him to spend any money to keep his mother comfortable. Her love of gardening and independence were such that she persisted in remaining on the old farm after her children had all founded 
homes of their own. When in 1771 she was at length persuaded to move into Fredericksburg, to a house and garden belonging to her son George, her son Charles and sonin-law, Colonel Fielding Lewis, made a valuation of her property, which amounted to $£ 215$ $11 \mathrm{~s} .8 \mathrm{~d}$. The document, which is among the Havemeyer manuscripts, shows that there were, at the "Home House," "43 Hoggs, Shoats and Pigs," 16 sheep, 24 head of cattle, 2 horses; at the "Quarters" (her dower land of 400 acres, some miles down the river), 4 horses, 6 oxen, 8 cows and calves, 39 hogs. On the two farms there were ten slaves. The lower farm was bringing her $£ 30$ per annum. Her house in Fredericksburg, still a comfortable residence, has a beautiful flower-garden, which stretches back to that of "Kenmore,"

- her daughter's residence. In her phaeton which, with a bay horse, she bequeathed to her daughter, she drove almost daily to the farm across the river. A covert near her monument is pointed out, where the old lady is said to have retired for meditation, but this is mythical: it is certain that the unusual piety ascribed to her does not tinge any one of her notes,- not even that to her son announcing that she is "going fast." Colonel 
Fielding Lewis was a vestryman, and was buried in the vestibule of St. George's Church; his grandson Robert Lewis, the Mayor, was a leading man in the church, and his daughter married the rector. Their piety was represented in the original design of Mary Washington's monument, which included four angels kneeling at the corners. However, Mary Washington's signature is found in Matthew Hale's "Contemplations," and in Hervey's "Meditations," - the latter of which was lately purchased by the Mount Vernon Association. Her monument was built by the generosity of Silas Burroughs of New-York, whose bankruptcy caused it to remain unfinished. It is to be hoped that it will be finished, and that the mistaken counsels of those who wish to substitute a new structure for the quaint and historical monument will not prevail.

Mary Washington's daughter, Betty, was remembered by Mr. Custis as "a majestic woman." The school in Fredericksburg was for both sexes, and Betty enjoyed its advantages longer than did her brother George, who had to leave in order to earn his living. Some of her letters have been preserved, and are written in a neat and clear way. They 
are to her brother George, to whom she was devoted, consulting him through life on every important matter. The following, though not so good an example as some others, is given here because it has not appeared, 1 believe, in any publication. I am indebted for a copy (exact) of it to Captain Henry Howell Lewis of Baltimore.

\section{"Mount Vernon, Sept. 21, 1779.
"My Dear Brother,
"Yours of the 27th of June I received, \\ "Mount Vernon, Sept. 21, 1779.
"My Dear Brother,
"Yours of the 27th of June I received,} with the enclosed from Mr. Peake, also the miniature likeness, for which 1 am much indebted. There was no mention made in your letter, or that of Mr. Peake, what the drawing amounted to. I will send the money by any person he may direct to receive the same.

"Mr. Lewis, Betty, and myself are just from the Berkeley Springs, to see my sister Washington, on our way home,- - and am happy to find her so hearty, and looking so well. And had you been here it would have completed my happiness.

"Oh! when will that day arrive when we will meet again. I trust in the Lord it will be soon,-'till when, you have the prayers and 
kind wishes for your health and happiness of your loving and

"Sincerely affectionate sister, "BETTY Lewis.

"P. S. Mr. Lewis, George and Betty join me in love and kind wishes.

"To General Washington, Philadelphia."

Betty was, however, a lady of deeds rather than words. The fame of her making cartridges in the Revolution, of her general leadership in the charitable affairs of Fredericksburg, and her excellence as a mother, remain to this day. Mrs. Lucas, who recently died at the age of ninety-four, told me that in childhood she was taught in a school-room located in the garden of Kenmore (the Lewis residence, though so named afterwards by the Gordon family), which she always understood had been opened there in the time of Betty Lewis. Although there may be some doubt about the extreme devoutness attributed by tradition to Mary Washington, Mrs. Throckmorton's testimony as to the piety of George, after his father's death, is unquestionable. The family always went to church, and George, to the end of life susceptible to eloquence, was 
under the influence of two eminent clergymen, John Moncure, rector of Overwharton parish, and James Marye, rector of St. George's parish. By the latter was founded and no doubt superintended the school attended by George Washington. His early copy-books bear witness to his religious sentiment. One of them contains a religious poem which may have been composed by one of the clergymen mentioned, as the spelling is not characteristic of the boy in whose careful writing it is found. It is headed-

\section{"ON CHRISTMAS DAY.}

"Assist me, Muse divine! to Sing the Morn, On which the Saviour of Mankind was born; But oh! what Numbers to the Theme can rise? Unless kind Angels aid me from the Skies! Methinks I see the tunefull Host descend, And with officious Joy the Scene attend! Hark, by their Hymns directed on the Road, The Gladsome Shepherds find the nascent God!

And view the Infant conscious of his Birth, Smiling bespeak Salvation to the Earth!

For when th'important Æra first drew near In which the great Messiah Should appear; 
And to accomplish his redeeming Love Beneath our Form should every Woe sustain, And by triumphant Suffering fix his Reign, Should for lost Man inTortures yield his Breath Dying to save us from eternal Death! Oh mystick union!-Salutary Grace! Incarnate God our Nature should embrace! That Deity should stoop to our Disguise! That man recover'd should regain the Skies! Dejected Adam! from thy grave ascend, And view the Serpent's Deadly Malice end; Adoring bless th'Almighty's boundless Grace That gave his Son a Ransome for thy Race! Oh never let my Soul this Day forget, But pay in graitfull praise her annual Debt To him, whom 'tis my Trust I shall [illegible] When Time, and Sin, and Death" [illegible]

The best of the poems found in Washington's early copy-books is one which l have endeavored to trace to some volume, without success. If it is of local authorship, I should incline to attribute it to his father. It indicates just the kind of culture that the elder Augustine would receive at Appleby, and has a smack of the wholesome freedom of heart and mind which belongs to the seventeenth century, in which he was born. 


\section{"TRUE HAPPINESS.}

"These are the things which once possessed Will make a life that's truly blessed:

A good estate on healthy soil, Not got by vice, nor yet by toil ; Round a warm fire a pleasant joke, With chimney ever free from smoke;

A strength entire, a sparkling bowl,

A quiet wife, a quiet soul,

A mind as well as body whole;

Prudent simplicity, constant friends,

A diet which no art commends;

A merry night without much drinking,

A happy thought without much thinking;

Each night by quiet sleep made short;

A will to be but what thou art:

Possessed of these all else defy,

And neither wish nor fear to die."

Captain Augustine Washington, in dividing the larger part of his property between his sons by the first "venter," to use his testamentary expression, no doubt reflected that his wife would bestow her own lands - about 1600 acres - on her children. But that was a long way off. What George needed was an education such as his half-brothers had received, 
and this the indefatigable captain would no doubt have secured him had he lived. But he left his second family land-poor. He had turned too much actual gold into possible iron. Then the iron crop was bequeathed to Lawrence, who was Eldest Son, Major, prospective Burgess, - the great man of the family,who must one day support an establishment in Williamsburg as well as Mount Vernon.

The half-brothers, who had both married wealthy wives, were disposed to be generous to George. At eleven he was taken to reside in the old mansion, "Wakefield," where Austin had settled with his young wife (Ann Aylett). There he was sent to Mr. Williams's day-school, which may have been in one of the old houses still standing in the village now known as Oak Grove. At "Wakefield" George had a home more luxurious than that of his father, though the number of varied wine-bottles found on the site of the house near Fredericksburg testified to the good living of the captain's household. Austin was by far the wealthiest of the Washingtons. Among these Havemeyer manuscripts is an appraisement of his property made on his decease by order of the Westmoreland Court, and dated November 30, 1762. Apart 
from real estate and from cash, his property amounted to the then large sum of $£ 4,6 \mathrm{r} 7$. There were 77 negroes, an amazing list of cattle, and 36 horses, - the names and descriptions of these proving that Austin kept a racing stud that must have won him many a prize at Fredericksburg and Williamsburg. One of his negroes is named "Appleby," and among the books that recall that old grammar-school are Homer, Virgil; and "sundry Latin books." Shakespeare (6 volumes) is included, but the library is not proportionate in extent to the importance of the rest of the establishment. One fiddle is appraised. There is costly furniture for the eight bedrooms, large quantities of mahogany and walnut for other rooms, several grand mirrors, and enough millinery and kid gloves (white and colored) to show that Mrs. Austin Washington must have been a rather dashing figure at the races.

It may be said, in passing, that it was probably, at least in part, on account of the wealth inherited by Austin's son, William Augustine Washington, that the general disregarded the terms of his half-brother Lawrence's will, by which, in case of his (the general's) death without issue, the Mount 
Vernon estate was to pass to Austin or his heirs. A law passed during the Revolution terminated entails, and the general bequeathed Mount Vernon to his own nephew Bushrod. At the close of his life the general, being somewhat pressed for money, was at various times assisted by William Augustine Washington, and to him he bequeathed several parcels of land, besides the first choice of his swords. A great-granddaughter of Austin, with whom George Washington found a home at his father's death, and her husband, John E. Wilson, Esq., make Wakefield still the seat of a refinement and hospitality which have survived all its vicissitudes.

The Washingtons were precocious lovers, and George was no exception. There are many traditionary claimants to the honor of having been vainly wooed by the great man in his youth. I will not name these fair and fabulous sweethearts, but must affirm that the three principal ones are historically impossible: one he certainly never saw until she was married; another he tells a correspondent he might have been pleased with had he not been already in love; a third was but a child when he declared his passion for the "Lowland Beauty." George no doubt 
had his boyish fancies, and one may have been the subject of an acrostic in his journal, certainly his own composition :

"From your bright sparkling Eyes, I was undone;

Rays, you have ; more transparent than the Sun,

Amidst its glory in the rising Day,

None can you equal in your bright array;

Constant in your calm and unspotted Mind; Equal to all, but will to none Prove kind,

So knowing, seldom one so Young you'll Find.

Ah! woe's me, that I should Love and conceal,

Long have I wish'd, but never dare reveal,

Even though severely Love's Pains I feel :

Xerxes that great, was't free from Cupid's Dart,

And all the greatest Heroes, felt the smart."

The concluding lines are missing. No doubt the acrostic was on "Frances Alexander,"-perhaps a girl of that name who belonged to the family after which Alexandria was named. They were descendants of the first Earl of Stirling. Their land extended to Hunting Creek, and it is likely that George 
and Betty played in childhood with this Frances, daughter of Captain Philip Alexander, though she was two years older than he who was undone by her bright sparkling eyes, - unless, indeed, we are to suppose the writer at fifteen to be placing his pen at another's service. Or it may have been written in answer to some playful challenge of the fair Fanny. There was nothing playful, however, about George's real love-affair,- - his passion for the "Lowland Beauty," as he calls her in one of his letters concerning her, of which there are three existing as drafts (undated) in his journal. The "Lowland Beauty" has been satisfactorily identified by the discovery, by General Fitzhugh Lee, who told me that it was genuine, of a letter from Washington to William Fauntleroy, Sr., May 20, 1752, inclosing a letter to "Miss Betsy," and declaring his purpose to wait on her, "in hopes of a revocation of the former cruel sentence, and see if I cannot obtain an alteration in my favor." Betsy Fauntleroy was a veritable "Lowland Beauty," residing at Naylor's Hold on the Rappahannock, about fifteen miles from "Wakefield."

Mr. Robert T. Knox, of Fredericksburg, has made out for me the pedigree of the Fauntleroys. The first of the name in Virginia was 
the famous Moore Fauntleroy, a great-greatgrandson of Edward Lord Stourton. He came over in 1643 , and the grand Fauntleroy mansion on the Rappahannock may have been built by him. The "William Fauntleroy, Sr.," of Washington's letter was grandson of Moore; he married Apphia Bushrod, and his son William married his cousin Elizabeth Fauntleroy. These had an only daughter, Elizabeth,- the Miss Betsy of Washington's letter. She was born June 26, I736. As the letter of George Washington was written just after his return from the Barbadoes (March 4, 1752), and speaks of not having been able to visit the Fauntleroys on account of illness, his "cruel sentence" must have been received from Miss Betsy before his voyage, September 28, 1751. He was then under twenty, and the young lady under sixteen. She afterward married an Adams, and became the mother of the Hon. Thomas Adams.

On a recent tour down the Rappahannock I found to my dismay that the ancient mansion of the Fauntleroys had been pulled down by its owner in 1891. Near the site of that superb mansion, whose beautiful park fringed the river with stately trees and flowers, stands now a frame house, plebeian enough to make 
the great cavalier Moore Fauntleroy turn over in his grave. What twilight walks and soft whispers went on beneath the grove of which but two or three trees remain! What songs on the moonlit waters! What revels in the great halls! There were aboriginal lords of the land there before Moore Fauntleroy led in the work of their extermination; now his proud race and their edifices have also become extinct. The young Washington who vainly pleaded for the hand of the Lowland Beauty presently unsheathed his sword, and now the democratic grass waves alike over the wigwam of the Indian and the palace of the Fauntleroys.

The river glides on, as it glided past the perished dreamland of young George Washington. It expands into a seaward highway on which the broken-hearted lover would fain travel; his spirit could find more repose amid the billows than in being tossed from one home to another as "a poor relation." But above the river moves invisibly the mightier current of events. One may speculate what might have been the course of history had George Washington then married the heiress, and become the master of Fauntleroy House. Was Betsy, even in her child- 
hood, to leave her great park and mansion, and her kinsmen, educated in universities, to share the lot of a hollow-chested youth whose brother was sinking with consumption, who had not means to remain even in Fredericksburg school, and whose land did not yield enough corn to cover the ribs of his horse? The letter of George Washington, printed in facsimile in this book, is sufficiently pathetic. His half-brother, Lawrence, to whom it is written, is a Burgess at Williamsburg; William Fairfax also; so there is no home for him at Mount Vernon or Belvoir. At Williamsburg, too, the fortunate young gentry of the colony are studying classics in William and Mary College, and acquiring in its fine social circle such polish as that which will enable young Adams to win the heiress of Fauntleroy. But poor George, at seventeen, must stay on the farm for lack of corn enough to support his horse, and be burdened with the widow's worries about her negro quarters. The five years' use of the farm at Bridge Creek left her by her husband has come to an end,- probably her main resource. How far away now appear these troubles under the later splendor.of this man's career! Lately I saw on the edge of the Rap- 
De 



\section{Thope your bough is much menost sincest}

vars you lavk, if vo likervive hovel you have grven over the thoughts of. leaving birginial.

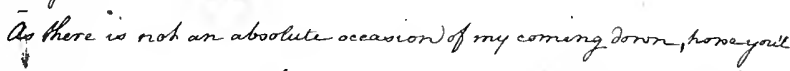

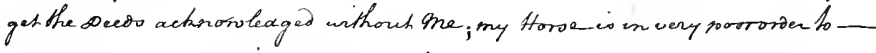
undees tathe wech a fourney, and es in no likelekood of mending for wankey born oufficient to cuspoorh hims tho' if there be any centainly in the afoom blyb not rioing unliut the lacler ena of Nbay, will yf can be conven by that;

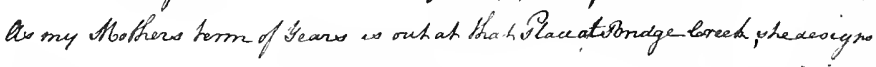

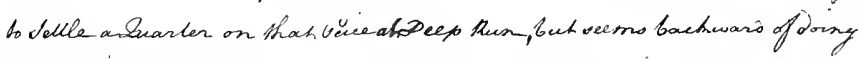
it unciul the Onght is made grot, for tear of aceidento.

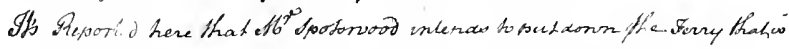

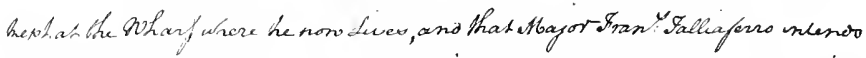
10 roctition the afoumbly for an ach to have it hesph from his Htowe oven against

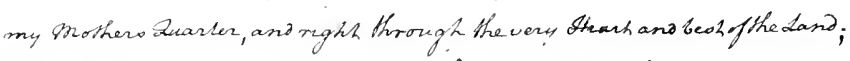

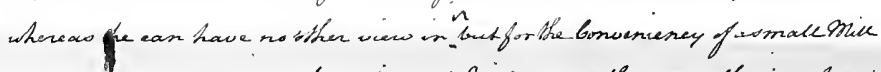

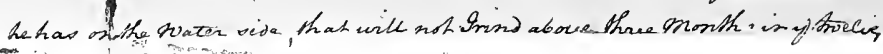

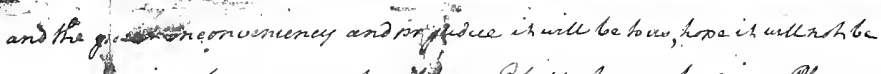

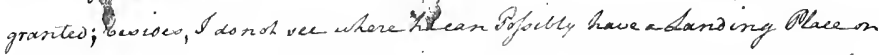

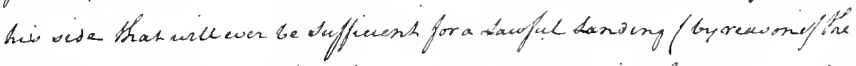

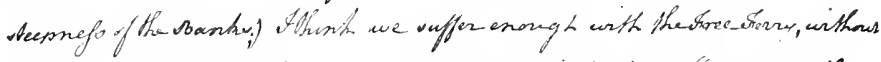
without buing tronbled with ouch an unjust and inequitow velution as that,

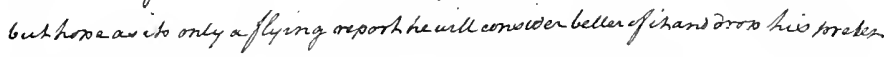

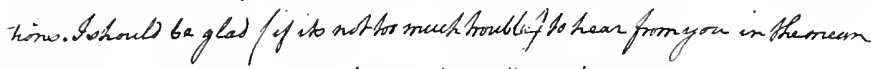

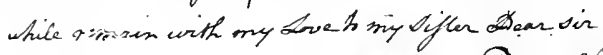




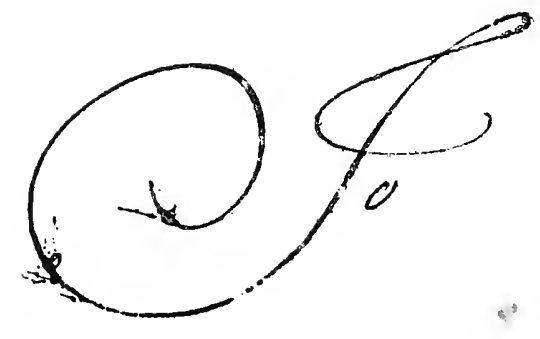

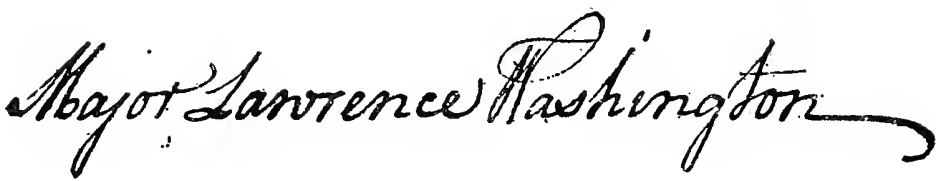

ah

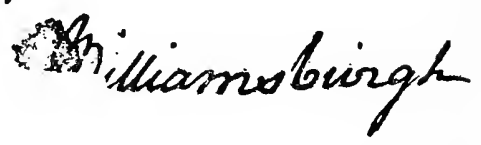

SUPERSCRIPTION OF LETTER, DATED MAY 5, I749, FROM GEORGE WASHINGTON TO MAJOR LAWRENCE WASHINGTON AT WILLIAMSBURGH, VA. 
pahannock the ruin of that same mill, to which the letter alludes, and on the heights near it uninhabited cabins that may be the very same that stood on the widow's lower farm, threatened by Taliaferro's proposed ferry. These poor things once meant bread or the want of it to the Widow Washington and her five children. They also meant humiliation and disappointment to the lover of the Lowland Beauty. He will roam among the Indians, and survey my lord's lands, and write of "her that's pityless" verses that amuse the dry historian:

"Ile sleep amongst my most inveterate Foes, And with gladness never wish to wake. In deluding sleepings let my eyelids close, That in an enraptured dream I may In a soft lulling sleep and gentle repose Possess those joys denied by day.'

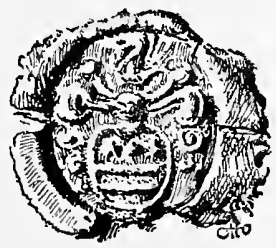




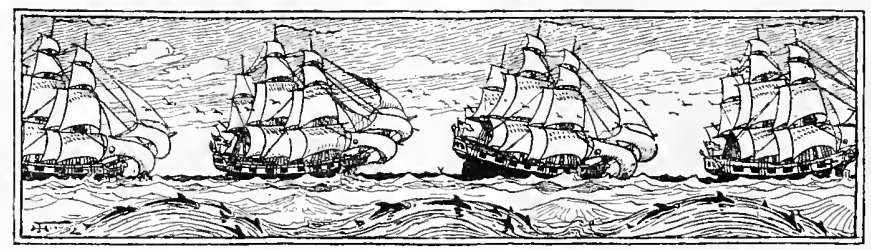

V

After Cartagena

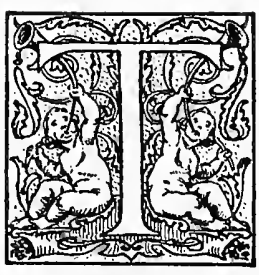

HE Journal of the Virginia Council, August 6, 1740, records the issue of orders to officers in the Cartagena expedition: "Captains, Lawrence Washington, Charles Walker, Richard Bushrod, - Mercer; Lieutenants, Francis Moss, - Bellamy, Lewis Browne; Ensigns, William Fitzhugh, Hugh Rose, —_ Young, Pilott." (Hayden's "Va.Genealogies,"p.494.) In the English House of Commons, Admiral Vernon, who had won some glory in the sea-fight against Spain in 1702 , boasted that 
Porto Bello could be taken with six ships. England took him at his word, and he made it good. Porto Bello was taken with six men-of-war in November, 1739. But it proved a perilous victory. On March 4, 1741, Admiral Vernon appeared before Cartagena, then in the Viceroyalty of New Granada, with 29 ships of the line, 80 smaller vessels, 15,000 sailors, 12,000 land troops, and met with an awful repulse, most of the army being slain, and large numbers scattered to perish on islands of sickness. Among the forces was the Virginia regiment of which Sir William Gooch was chief and Lawrence Washington next in command. Sir William returned soon after the disaster, broken in health, and seems to have left the Virginians in Jamaica under command of Lawrence Washington. The latter returned to Virginia near the close of 1742 .

This brief preface will enable the reader to understand better the subjoined letters to Lawrence Washington from his friends and comrades in England. Joseph Deane, writer of the first and of another, was clearly a trusty agent in Whitehaven of the Washingtons. His tone is that of intimacy with both Lawrence and his father. Canon Mathews, of Appleby, England, where Augustine (men- 
tioned in the following letter) was at school, informs me that the Deane family belonged to that place (1696). It is near Whitehaven. There is no address on the letter, which was probably inclosed:

\section{"Dear Sir :}

"It was a very great satisfaction and pleasure to me and to all your friends in having the favour of yours from the Harbour of Carthagena ye 3 I March last, and tho wee have not had that favour repeated, and great misfortunes and mortallity hath attended you, yet I hope to God you are still in being, and that he hath and will protect you at all times; this is the sincere prayer of your affectionate Friend.

"Wee have had dismall accounts; how to judge is very uncertain; and upon my word I am under the greatest uneasiness for your p'servacion, so that 1 beg you will let me hear from you. I will not enlarge much, being afraid I am writing to one, not of this world, so that I know not whose hands this may fall into. I hear Conll Gouge hath wrote to England and accuses your Virginians of Cowardice, and that they are all or most of them back. I hope its not true; but 
be as it will 1 beg you will keep up your spirits. Your Brother and all Friends is well and at your service; and upon my word he is grown a pretty young fellow. Pray also give me directions to proseed. As to state affairs I am no judge, but your Fine Admirall hath got great aplause tho' he cu'd not take the Town. And some is blamed for storming the ffort (much) without first a breach.

"All friends hear is well except your once much admired Mrs. Milham who is just a heap of coruption (so uncertain is this world), and must be dead ea'r this comes to hand. All hear join's in our kind love to you, and I am

"Dear Sir,

"Your most affect. Humble serv't "Jos. Deane.

"WT Haven, July 24, I741.

"Its uncertain this cuming to your hand yet wou'd neglect no opportunity to show my regards for you."

It will be seen by the above that Admiral Vernon's popularity was too great to fall by his failure. In fact, he resumed his place in 
Parliament. However, in 1745 he quarreled with the Admiralty, and his name was struck off the naval list. He is now mainly remembered as the hero of a failure, whose name was given to the mansion of Washington.

The next letter is official, and bears the superscription: "To Captain Lau. Washington of Col. Gooch's Regimt of Foot. Pr. Captain Fitzhugh." (This was William Fitzhugh, of Westmoreland, Virginia.) It seems to have reached Virginia before Lawrence, and, strange to say, was delivered to William Fairfax,being marked: "Recd Sept. 23, W. Fx." Possibly, however, it was received at Williamsburg, William Fairfax being in the Council, and confided to him as the particular friend of Lawrence's father, then residing at Fredericksburg.

"Sir,

"This comes with your Account of Clearinge from the date of your Commission to 24 December 1740 Balance whereof is Eighteen Pounds five shillings, and $1 / 2$, and waits your order.

"It was but this day that I could get that money from the Pay Office, and no more Clearings can be received till May or June 
next at soonest for want of Muster Rolls : Such as have been sent home can be of no use, the Docket part which governs the Credit of the Muster Roll being Cancelled by Endorsements; so We must get these Rolls explained by Warrants from the King, or put into some other Way for Payment.

"Your Regiment is not particular herein all the others being, in the same Way; so soon as I can obtain the Proper Credits I shall write, before which I pray the favour that the Gentlemen will not draw on me; for it will be great Uneasiness to me to send back their Bills.

"This comes to the Northern Provinces where I reckon You will come upon the Reduction of the Regiment and I am present Busy for solliciting for the half Pay.

"I am Sir, Your most obedient "humble servant, "AlEXr Wilson.

"Queen Street Westmr: "6 Novemr I742."

The seal on the above letter is armorial: two chevrons between three mullets, the crest being a shell. 
The next letter is from the general of the land forces in the Cartagena expedition.

"Sr,

"I am favour'd with yours of Jan: 17 th, which gives me a great deal of pleasure, as it confirms the account of your safe arrivall in Virginia, with the soldiers committed to your charge, and of their being without any difficulty dispers'd to their respective colonys.

"I have I do assure you, labour'd to the utmost of my power to serve the reduc'd officers of your Corps, and I flatter myself that there will be a provision made for the whole, soon after the Parliament rises; but am still of the same opinion that your coming over hither will answer no end, but the occasioning you unnecessary trouble and expence, and that your interest will not in any wise suffer by your absence.

"I am, Sr your very faithfull

"and humble servant,

"THOS. WENTWORTH.

"London, Ap: the I 7 th, I743.

"CApt Washington."

Captain Lawrence Washington returned from the unfortunate expedition to find a 
happy outlook at home. The house his father had been building for him in Fairfaxthe county was just formed, 1742-was nearly completed. It is probable that he stayed with the Fairfaxes at Belvoir; at any rate, he persuaded Ann Fairfax to become mistress of the new mansion, which he promptly named Mount Vernon. His father, it will be remembered, died on April 12, 1743, and it is said that the marriage was on that account postponed until July 19 . It is rather remarkable, however, that in writing to his friends in England Major Washington seems to have omitted mention of his father's death. This may be gathered from the following congratulatory letters.

"Dear Sir, pleasure one two accts. First that you have escaped many daingers and returned in peace, and 2 dly that you are happ'ly fixed to a Young Lady in Whome I sincerely wish you all the cumford and happeness this life can aford. My Wife joins with me in the same good wishess and desires you will make our complimts in a politer way then my Pen is masr of to Your Lady. 
"I writ to you by the Howard since wch wee have had no News however I have sent you and yr Brother all the journals I cu'd pick up. You know what this Country afords. if I can assist my freind in anything I beg You will let me know. I shall write to you by other ships from time to time and I hope you will do the same to me.

"I am Dear Sir your very Affect

"Huml Servt,

"Jos: DeANE.

"Wt Haven, Nov. Ioth, 1743.

"P. S. You must excuse Bror Robinson's not writting I told him I woud writ when the first Ships was ready to sail but wee have a Surveyr in the $[\mathrm{sic}]$ that prevents me."

The next letter is from Lawrence Washington's teacher in England, who addresses him as "Major," - his title after becoming Adjutant-General of one of the four military districts of Virginia, to which place his brother George succeeded (£150 per annum).

\section{"Appleby, Novr. 13. 1743.}

"You tell me, Dear Major Washington, on the 19th of July, that you had then taken your 
residence upon Mount Vernon, and give me to understand that in a few hours after writing you might probably be upon your Mons Veneris. A happy situation, believe me, I think you to be in. If I had not thought so, I should not have come there myself; for be it known to you I was married also on ye $12^{\text {th }}$ of May, ye day sacred and solemn to all schoolmasters of Appleby, but particularly so to me, before I made it my wedding day; being not only ye day upon which ye school was founded (as you may yet remember, if you have not forgot Nansey Huetson) but ye day likewise on which my Presentation to the School bore date just 20 years before. And as it had prov'd a happy day to me, productive of much profit and pleasure too for 20 years together, I ventured to make it an Era from which to date so considerable a Revolution in my Life; and I bless God for it ; thus far I find my satisfaction improved, and have no apprehension of any abatement but hope and prospects of farther improvement still.

"But why all this upon my self, when I am writing a Letter of -)gratulation to my friend? To let my friend know that my -)gratulation must be ye more sincere, because I feel ye joy that I give him upon ye occasion. And to con- 
clude with as hearty and as good a Wish as I can make. I wish you, my Dear, and your Wife as happy as I and mine are.

"The Woman I married is ye daughter of Mr. Hartley of Kirby-steven who had a Bror. Hugh at school when you was here, I believe; and another whose name was Alderson when Austin was here. She 's just io years younger than 1 (pretty much as 'tis with your's). I wanted about 15 weeks of 42 upon my wedding day. I hope your Father and his family are all well. I beg my best respects to him and Honest Austin, and am with sincere regard for you and your good Lady

"Dear Lawrence,

"your most Affectionate Friend "and very Humble Servant

RI: YATES.

"This comes down to Honest Joe Deane to whom I leave ye direction of it."

Canon Mathews writes me from Appleby Vicarage :

"Richard Yates was a well known master of Appleby Grammar School - then one of the best known schools in the North of England, 
in the first part of last century. He was a man of literary tastes and an author. In our Registers, which are alas very imperfect, I find, 'Jane dr. of Mr. Ri. Yates baptized Mar. 5, 1745.' Nancy Huetson, mentioned in Mr. Yates' letter, was for many years a Matron at Appleby Grammar School, and left all her savings to found an annual Treat for the boys on a certain date each year-probably the 12th May alluded to by Mr. Yates. This was held at an inn in Appleby until it was found to lead to abuse and was suppressed."

There is another letter of "honest Joe Deane," as Yates calls him.

"Dear Capt Washington,

"Yours at all times (if I may own it) gives me great pleasure, so that I hope you will not Neglect renewing that pleasure when every opportunity offers.

"I wonder you shud not hear from me. I seldom miss embrasing all offers and will continue so long as I find my Letters are not troublesome. My Bror Robinson hath I fancy received the value of your Bill. I have heard nothing to the Contrary. Poor Wilkin is dead. Dr. Skelbeck is Mayor, and Mr. Yates 
is marred; that's all the Alterations I know there. The warr was expected to be hott in Flanders but its quite otherwise. I am afraid its a trade now. Wee have a company of Blackney's Regement in this Town and the captain's Name is Gordon. I find he went out upon the same footing you did and is now in full pay, so that if you was to cume over you woud be the same. He tells me he knows you very well and seems to blame you in not cuming over (but this is not to Advise you for I know nothing about it.) He further tells me he had a dispute about the Seniority but you got it.

"This warr I am afraid will distress the Planters but its only living within due bounds at first (this advise may be given but not so easily taken.) I cud not learn from Mrs. Smith the reason of her cuming away.

"I have sent you the last papers and if I can serve you in any thing hear, pray let me know. I had the worst luck with the Walnutt [? oil that ever Fellow had, wee lost but two ships and it was both them that had it in.

"Wee have little or no news hear, but I hope to God the King of Prussia will never get out of Boheamia he had the Bullo [? bullion] 
and hath still if he woud be honest, but I hope no body will trust him now.

"My Wife joins in our very kind love to you and your Lady, and I am with due regard

"Dear Sir, your most Obedt
"and most Humle Servt.

"Jos. Deane.

"Wt Haven, Nov. 6, 1744."

The following, "To Capt. Washington," is written on paper with water-mark "Culloden. Dettingen"; also a crest seal — a sea-horse and coronet.

"Dear Captain,

"Montrose, Nov. I $3^{\text {th }, ~} 1749$.

"You'l excuse my not giving you your proper title, as I dare say you are long before this become a Colonel, but you ha' not been so kind as to inform me thereof, tho $I$ have wrote sev'al times to you since I had the pleasure of hearing from you. Most of our Corps $\mathrm{y}^{\mathrm{t}}$ are living are now in the Army, very few by the reduction on half pay. I am just become Eldest Captain. None of us yet are ffield Officers but Bollocks Merser, who has beat us all with his Hams of Bacon. Poor Lowry is 
lately dead in Ireland and Milburn dyed in Eding this Spring.-You wou'd find by the papers yt we did not reep many Laurells ye last War in fflanders, no more than in the West Indies. I was in the two Battles of Rasso and La Poll, at the latter of which I recd a wound in my Ancle $\mathrm{y}^{\mathrm{t}}$ had like to have made me an Invalid for life, which was likewise dispaired off, but by the help of a good Heart and good Constitution I have got ye better of it and can still walk tolerably well, but to my great mortification I have not yet dared to venture upon a Country Dance. You'l say perhaps ye matter is not very great, as my dancing days ought to be pretty well over, but hold a blow there I am as young as ever I was tho' not yet married but I threaten ye Scotch Lasses very hard. Bob Poins is lately dead, did I know where she was I would have a stroke at my old flame his Widdow, if she durst venter again after having had so bad a Husband but they will venter and a man might venter too was he sure of having as good luck as you have had, and you can't be angry at me, if I am in love with your Lady, because you yr self are the cause of it. Pray my Complyments to Fitzhue who 1 hear has beat up the Quarters of a Widdow, to whom I wish all Happiness. I have 
been this summer with a Detachmt of our Regiment at Work upon the Roads in ye Highlands, where wee had ye weather much colder than 'tis with you in Winter, and so wet yt we had but 7 fine days in 3 months. I have not been here a week 'tis a most beautiful situation and ye Adjacent Country pleasant enough, so that I seem to be transported out of Purgatory into Paradise. I find your Governor [Gooch] is coming over and Colo Legh [Lee] is to be president [of the Ohio Company] to whom you'l please to make my Complyments and to all my old Acquaintance. I coud spend a Twelve Month amongst you with a great deal of pleasure; but 'tis not very likely that that will ever happen. We have Work cut out for us in this Kingdom for 5 or 6 years. Tho' we you know have no certain abiding place, yet wherever I am I shall always be "D Sr,

"Your assured friend and "Very hble servt "T. STAFFORD.

"If you have not quite forgot your old acquaintance let me hear from you by ye first opportunity, and direct for me in Lieut General Pulteney's Regiment in Scotland." 


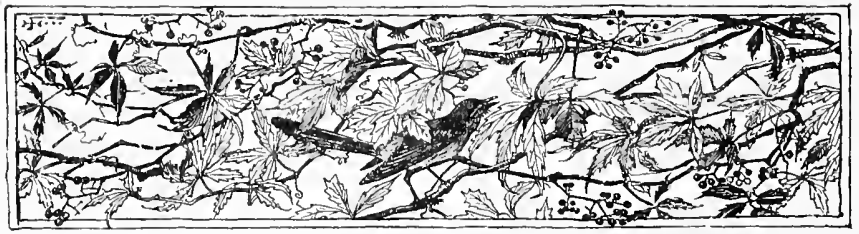

VI

The Virginians

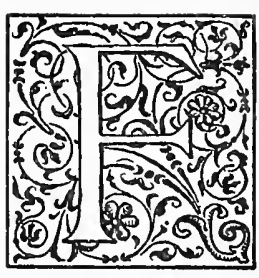

Rom the Chesapeake ("Mother of Waters") extend, like fingers from a mighty palm, Virginia's tidal rivers,--Potomack, Rappahannock, York, Mattaponi, James. These and their confluents gathered up the produce of the land. On each of the smaller streams was a fleet of flat-bottomed scows which could meet the wheeled barges of the interior and convey their loads to the sea-vessels at their mouths. The ships were wafted by the breath of prayer. Here is one of the many 
bills of lading before me,- - the words not of the printed form given in italics:

"Shipped by the Grace of God, in good order and well conditioned, by the Hoñble Jobn Carter, Esq. on the proper Accot and risque of the Estate of Robt Carter of Nomony in and upon the good Ship Cbarles, whereof is Master under God for this present Voyage Thomas Teage, and now riding at anchor in the [Potomack], and by God's Grace bound for London, [that is] to say Thirty-two Hbds. of Tobacco, being marked and numbered as in the Margent, and are to be delivered in the like good order and well conditioned at the aforesaid Port of London (the danger of the Seas only excepted) unto $M r$. Edward Atbawes or to bis Assigns, he or they paying Fraight for the said Goods at the Rate of Eight pounds Sterling p. tunn with Primage and Avarage accustomed. In Witness whereof the Master or Purser of the said Ship have affirmed to 2 Bills of Lading all of this tenor and date; the one of which 2 Bills being accomplished, the other $I$ to stand void; and so God send the good Ship to her desired Port in safety. Amen. Dated in Virginia, Aug. 9tb. 1738. - Tbomas 
Teage." Margin: "Impost and Cocket not paid."

The young people, as they saw the huge hogsheads rolled on the wharf and lifted into the ship, added many prayers to that of the bill of lading for the good ship's safe voyage. For the said consignee Athawes was to youthful Virginians hardly less august a personage than Majesty himself. That mercantile magician it was who waved his wand over these grimy hogsheads from Virginia, and returned them as ribbons, silks, necklaces, or whatever might be desired. In two or three places-Aquia, Fredericksburg, Urbannathere grew up "stores," which yielded as many varieties of things as India's fabulous Wish Tree, and these were much frequented; but among the gentry there was always éclat about the costume or article imported directly from London. Everything must be labeled "English," insomuch that fanciers used to sell the songsters unknown to England, if they sang particularly well, as "English mocking birds." A survival from this period is found in the local superstitions surrounding colonial churches, and the earlier mansions, that they are built of bricks made in 
England. Many years ago Dr. Philip Slaughter offered a considerable reward for any evidence that bricks were imported for such edifices, but, as he told me, none was forthcoming. William Randolph, at Turkey Island in James River, "King Carter," at Corotoman on the Rappahannock, and Colonel Henry Willis, at Fredericksburg, certainly had large brick-kilns, and there is no reason to doubt that this was one of the earliest industries of Virginia. The oldest church standing in Virginia is that at Smithfield, built in 1632. The bricks of the foundation of a neighboring farm-house, "White Marsh," of like antiquity, occasionally show on them the footprints of fowls and dogs, made while they were soft, and showing that they were made on the farm.

It was not for brick-laden ships that young eyes were strained down the great rivers, but for the loads of pretty things that were presently distributed up the creeks and roads to be displayed in many a mansion. The invoices of millinery and jewelry were large. The ladies and gentlemen were more particular about attire than the Londoners. In that swarming population one may pass unobserved, but in the sparse colony every costume 
counts. Even the gaily dressed beau, who survived in the ridiculed "dandy" of democratic times, was a useful decoration of colonial society. The old Virginia gentleman's finery was taken from him bit by bit: first his sword, which used to be left in a swordrack at the church door when he went in to kneel before the Prince of Peace; then his wig; next his knee-breeches, buckles, and silken hose. But there are elderly Virginians who in youth wore huge shoe-buckles, and remember their grandfathers in daily dresscoats with brass buttons, shirt-ruffles, snowy cravats flowing through golden rings, and even an occasional queue lingering from the lost wig. As for grandma's snowy rubyclasped turban, it may even yet be seen in some counties. There was always company. Even after the Revolution Washington described his house, Mount Vernon, as "a well-resorted tavern," and said that for twenty years his family never once dined alone. But in colonial times, when there were few taverns, every mansion was a hotel. English and colonial officers, royal commissioners, agents, travelers, were always at hand, and perhaps seeking some fair Virginian's hand. The families had a custom of "spending the 
day" with one another. After due prearrangement all the members of a household, young and old, start off to travel five, ten, fifteen miles to visit some "neighbor," arriving in the forenoon. The elder folks play whist for moderate stakes, the marriageable youth play graces, the boys chermony, or bandy, or perhaps join the girls at tag, blindman's buff, and other games on the lawn. They all dine magnificently at two, and the guests journey home after early tea. Christenings and weddings, of course, give rise to great family gatherings. And there are famous crabbing parties on the lower and deeper parts of the rivers. In the early morning they sail out on a vessel large enough for a dance. Each lady is provided with a fishing-line made of hickory-bark, at the end a bit of fat meat around which the crabs gather like green petals; the beau beside her lowers his hand-net, and woe is him if he is too abrupt and does not lift the crustacean flower on deck. They are emptied into the huge boiling-pot, where they blithely swim about till red. Compassion is soothed with the superstition that the crabs like it. There is much fox-hunting, some deer-shooting, and more sport with ducks and wild turkeys. 
The duk-shooter sometmes lies hid in his boat and drifts among the ducks, his gum through a port-hole. The turkey huntsman carries a whistle, which must be made from a turkey-bonc, with which he can innitate the note of a turkey. The flock being tushed by a dow. which is then carricd to a distance, the sportsman sits in :mbush and with his turkey-bone deludes the birds, which are trying to get together agan. So the old sin of secthing a kid in its mother's milk went on. The colonial ladies were not huntresses, but they senerally wathered at a "meet," and the humting-day msually closed with a dance. Even church-going was a kind of picnic. The fumilies, sathered from many miles romal, earried hampers, and between the morning and atternoon services a communal feast was laid in the grove, young ladies being the waters. Such being the scene, it is not wonderful that in country parishes so few presentments are found for non-attendance at church. There were also expeditions to the court-house, which was often crowded by ladies listening to the lamous lawyers. with whom they presently danced at the invariable ball. Then there were races, the most important being at Williamsburg and 
Fredericksburg. Those of Fredericksburg occurred during its great fairs,-spring and autumn,-when there were masquerades, river-festivals, and all manner of gaieties. The town became a bazaar of beauty. Many marriages of the Rappahannock region were arranged at the Fredericksburg Fair.

With all these gaieties, the colonial dame in Virginia had to "come out" pretty early: it was generally when of the age at which Shakespeare's Juliet married-fourteen. There were not enough ladies to go round, so to say, without levying on the school-room. My reader may be interested in the following list of articles, representing part of the outfit of one of these little ladies for perhaps her first season in society. It is copied from the original invoice, in my possession, of purchases forwarded from London on an order of Colonel John Lewis for his wards, and received at Corotoman, June 30, 1739:

"For Elizabetb Carter, 14 years old. A Cap, Ruffles, and tucker, the lace $5 s$. per yard; I pair white Stays; 8 pair white kid gloves; 2 pair coloured ditto; 2 pair worsted Hose; 3 pair thread ditto; I pair silk shoes laced; I pair morocco ditto; 4 pair plain Spanish dit- 
to ; 2 pair calf ditto; 1 mask; 1 Fan; I Necklace; I Girdle and Buckle; I peice fashionable Calico; 4 yards Ribbon for knots; I Hoop Coat; I Hatt; I yard and half of Cambrick; a Mantua and Coat of Slite lutestring."

1 add, also, the provision in the same order for "Master Carter."

"For Robert Carter, 12 years old. One suit of winter cloaths; 6 pair Shoes and 2 pr. Pumps; 4 pair worked Hose; 4 pair Thread ditto; 2 Hatts; 2 pair colourd Gloves and 2 pair white; 15 Ells Holland $6 s . ; 15$ yards brown Holland; 1 pair Shoe Buckles; 1 pr. blew and white Kenting Handkfs."

One now and then meets with items in old letters suggesting a probability that these Virginia ladies, who put on their "war-paint" so early, were not expected to lay it aside altogether even after marriage. Custom must not "stale her infinite variety" who, without daughters to help, must entertain many fine gentlemen far away in the depth of some lonely estate. The time must not be allowed to drag for want of a little flirtation. The pretty hostess must gallop with her guest 
about the estate, she must challenge him at graces or archery, and her evening costume must be charming. It must be added, however, that there never was a society freer from marital scandals than that of colonial Virginia. Although duels about sweethearts were not infrequent, I do not remember to have heard or read of any about wives. Whether this is to be ascribed to the virtue or the freedom and complaisance of the time it is not easy to determine. However this may be, there is no doubt that a survival of the beautifullest went on in the colony. Marriages of convenience were comparatively few; the beauty, however impecunious, however poor her parental cottage, was sure to have her train of admirers. And everybody married. The men married again and again. General Washington's brother Samuel married five times, and was under fifty when he died. To the planter on his vast estate life was not worth living without a wife. A Swiss traveler, M. Droz, who passed some time in the Northern Neck before the Revolution, wrote a book (Récit Fidele de Mes Aventures) in which he describes the ladies as "bounteous in size and manners." "Most of the women are quite pretty, and are insinuating in their manners, if they find 
you so. When you ask them if they would like to have husbands, they reply with a good grace that it is just what they desire." "It is not rare to see young girls of fifteen marry an old man."

It must be credited to colonial society in old Virginia that the gentlemen and ladies were not much separated in their amusements or occupations. The country was rather too rough for the ladies to join in the fox-hunt, and we may feel pretty certain that they did not attend the cock-fight. This miserable amusement was highly respectable - as much so as the bull-fight in Spain. It may be mentioned, by the way, that in the old Academy at Appleby, England, where the Washingtons were educated, there was a regulation that a "cock-penny" should be paid by each boy on Easter Tuesday to the master, to provide them with a cock-fight. We need not wonder that George Washington, whose father and brothers were there educated, records (1752) in his journal, now time-worn: "A Great Main of ... cks fought in Yorktown .. tween Glouster and York for 5 pistoles each battle and Ioo ye odd I left it with Colo Lewis before it was decided." The progress of these pre-revolutionary battles at Yorktown, and the final surrender, remain unknown to history. 
The chief lady on a plantation held a position of high responsibility, and, by the number of eminent immigrants who remarried in Virginia, I judge that few English ladies were equal to the burden. She had to govern a number of slaves, in the absence of her husband at the county courts or at the House of Burgesses, and she had to oversee the overseers. Still more important was her office of physician to the negroes and the convict laborers. She had a closet filled with drugs, studied medical books, and did everything except phlebotomy, for which some workman on the estate was usually trained,- - like the blacksmith who, at George Washington's command, reluctantly let out the great man's life-blood. Some of these ladies, on becoming widows, and left with small means, repaired to one or another settlement and became regular practitioners. For some years after the foundation of Fredericksburg the only physician there was Mrs. Livingston. She was by no means a quack, or mere herbalist. The Vestry of St. George's Church paid her with substantial tobacco-fees for attending the poor invalids of the parish. She is mentioned by Colonel William Byrd, of Westover, who visited Fredericksburg in 1732 . In another place, apparently near Germanna, on 
the upper Rappahannock,-where Governor Spotswood had introduced German ironworkers and vintagers,-Colonel William Byrd was delayed by a storm for two days at the house of Mrs. Fleming, a noted "doctress." He gives her treatment for the bloody flux. "For this disease," he says, "she told me she used very simple remedies, in most cases with very good success. She did the business either with hartshorne, drinks that had ye plantain leaves boiled in them, or with a strong decoction of St. Andrew's Cross [supposed Ascyrum Crux-Andrea], in new milk instead of water." Fleming was an early name on the Rappahannock, - the second wife of Lawrence Washington, immigrant, was a widow of that name.

The condition of literature and education in colonial Virginia has been erroneously inferred from Governor Sir William Berkeley's report of the same under his administration, 1641-1677: "I thank God there are no free schools nor printing, and I hope we shall not have these hundred years: for learning has brought disobedience and heresy and sects into the world, and printing has divulged them, and libels on the best governments. God keep us from both!" Before the seven- 
teenth century was out William and Mary College was flourishing, and elementary schools were springing up; in 1736 a spirited newspaper was founded at Williamsburg, where there was also a good theatre in which Shakespeare's plays were acted; and in the same year was established the first of the free schools so much dreaded by Sir William. This was the Eaton Free School in Elizabeth County. Twelve years later education was made compulsory in Virginia. The law of 1748 provided that where persons were incapable of supporting or bringing up their children, or neglected their education, churchwardens should bind out such children as apprentices on condition that they should be taught the rudiments of learning and a trade. Every parish had its school, and the only reason why large academies were not generally founded before the Revolution was that the gentry found it easy and more satisfactory to send their sons to the great schools of England. Girls were generally taught in their homes by tutors; but in towns the parish schools were attended by both sexes. Such was the case with the admirable school founded at Fredericksburg (about I740) by the Rev. James Marye and some French peo- 
ple: the school in which three of our Presidents were taught - Washington, Madison, and Monroe. Major Byrd Willis has left a manuscript, loaned me by his granddaughter (Mrs. Tayloe of Fredericksburg), in which he says: "My father, Lewis Willis, was a schoolmate of General Washington, his cousin, who was two years his senior. He spoke of the General's industry and assiduity at school as very remarkable. Whilst his brother [Samuel] and other boys at playtime were at bandy and other games, he was behind the door ciphering. But one youthful ebullition is handed down while at that school, and that was romping with one of the largest girls; this was so unusual that it excited no little comment among the other lads."

In most of the homes of Virginia there were fine libraries, which generally included French as well as ancient classics. No one can read the letters of the colonial ladies without recognizing that they were well educated. Two of the best historical narratives of the seventeenth century are by ladies. One is that of Verlinda Stone, wife of the Governor of Maryland (then in prison), to Lord Baltimore, giving an account of the struggle between the proprietary government and the Puritans; the 
other, Mrs. Ann Cotton's history of Bacon's Rebellion. These ladies may, indeed, have been born in England, but they had long resided in Virginia, and there is no reason to suppose that the culture shown in their lucid and simple narratives was greater than that of the ladies by whom they were surrounded.

In the earlier part of the last century Virginia was, socially, a very happy colony. The Rev. Hugh Jones reported, in 1724, that there were no poor people therein, and for more than a quarter of a century thereafter the same was true of the country places. In settlements like Williamsburg and Fredericksburg a few free laborers dwelt who, when ill, fell on the parish, and one or two families of the gentry, brought low by misfortune, might require assistance; but never was colony freer from evils of this kind. There is a mistaken impression that the "indented" white laborers in Virginia were chiefly English convicts, like those imported by Captain Augustine Washington. Such, however, was not the fact. The captain's grandfather had imported very respectable people, some, indeed, of the minor gentry,-one, for example, of the Gregory family with which his granddaughter intermarried. The earlier importations had been 
men, and it became important that more women should be brought over. But great care was taken to provide wives of respectable character. Free voyage was offered to such women as could bring good credentials, and they were guaranteed safe return if they should not desire to remain in the colony. But few returned. The husbands they found in Virginia were under service for a term of years only. I have in my possession a letter (undated) written to Robert Carter of Nomony, apparently by one of these wives, the handwriting and diction of which are those of an educated lady:

"Honour'd Sir,-When I saw you I was speaking to you concerning my two boys, and your answer was that you would consider about it. I should be glad to have an answer to it, for I want to move this fall nearer my husband, and at the same time I shou'd be glad to have my small children with me if your Honour pleases. As to my big children I should be glad to have them from your Honour, and to set your price on them - what I am to pay a year; hoping your Honour will not be too hard on me, as I shall have rent to pay, and then all to find in clothes; for it will always 
be my study to keep my payments good to you, and a comfort to me to have my children about me. Please to let me have an answer by the Bearer.

"I remain your Humble servant, "MARY HARRISON."

Soon after Bacon's Rebellion (1676) a hundred English girls emigrated to Virginia, who seem to have belonged to families of higher social position. One of them married a Fitzhugh, and probably most of them found suitable husbands.

On the Rappahannock and Potomack there were but few Africans before the middle of the last century; indeed there were only three or four thousand in the colony, and they were chiefly on the lower James River and on the York peninsula. The slaves were rarely overworked; they were not yet too pious to be merry, and those brought from Africa found Virginia a paradise compared with the savage countries they had left. On the Rappahannock their chief occupation was to gather tobacco and convey it on scows to the river's mouth for the ocean vessels. Every such flatboat, plenteous with rum, was the scene of perpetual dancing and laughter. Long after 
the dancing and laughter had ceased there remained - perhaps still remains - a superstition that sometimes in the dusk a mysterious scow passes down the Rappahannock, with phantom figures on it, and peals of laughter and song, with patter of the "breakdown" echoing along the shores.

Nevertheless, bright as was the horizon of old Virginia, the cloud was there, though no larger than a man's hand; it is represented by the mixture of race-horses, tobacco, and human chattels in a letter "to Landon Carter, Esq., at Landsdown in Richmond County. By Gumby":

"Dear Sir,

"SHIRLEY, July 22d, 1739.

"I think there was no occasion for your letter by Gumby, after I had said that you might send the Woman and Girl to Totusque and so to Corotoman if you disliked the Choice or price: and as to the long Dissertation about the Race Horse, it might well have been spared, when my Letter had left you at Liberty to go half of the Races or let them alone as you thought proper. Trinclo won the second Race near a length with Sam on his Back, and I shall give you Credit for the half 
of fifteen Pistoles and the half of 2 hhds. Tobacco, tho' I called no Witnesses to my Intentions. On the first race the loss was 20 Pistoles and 4 hhds. Tobacco, and 5 Pistoles on Chiswell's Mare against Randolph's Mare, half of which I charge to your Account, and this shall be the last of the Sort. My journey to Corotoman being stopt by the sickness of my Wife and Family, I desire the favour of you to send me a set of Bills of Exchange for $£ 100$ sterl by Simon Sallard, who has my Direction to wait on you for that purpose. I have nothing to do with your Bargains with Colonel Charles, nor do I enter into the Conscionableness or unconscionableness of his Demands, nor do I suppose that you are obliged to let him have that Girl, which for anything I know, may be worth more than both his horses; but if you can supply yourself with Slaves on better terms from Capt. Denham's ship, and those I sent you have received no injury from their journey, nor contracted any Distemper I could not foresee, you have still my free Consent to send ym to Totusque, from which Mr. Ledford may contrive them down to Corotoman.

"I am, Sir, your most affect. humble Serv't, "JOHN CARTER." 
This John Carter had a pretty long genealogical road behind him, according to a gentleman of Fredericksburg, who writes me: "The Carter family are kin to everybody in Virginia in some way, could you go back far enough. I have a pedigree of Carters of Shirley through the Spotswood tree, going back in a straight line to Adam and Eve- not a missing link." John must, therefore, have inherited a good deal of bad temper as well as pleasant. His note to his scholarly relative, Landon Carter, sounds rather surly, though we do not know the exact situation. It also looks as if in him the Carter tree had borne a sort of domestic slave-trader. Nor is there anything very sportive in his allusions to the races. He seems to mean business. But it was out of just this kind of man that the rebel was made who defied the Stamp Act. He is the domesticated Virginian whom England may rule nominally, but not really.

It may seem wonderful that the leading republicans should presently appear in these Barons, with their slaves and serfs; but they were by no means democrats in the "rightsof-man" sense. They were a sort of plantation peers, who had developed a system of self-government of which the landholder was 
the unit. The colony was divided early into eight shires, and after these had multiplied the county lieutenant maintained high gubernatorial dignity. He was originally called "commander of plantations." He executed the laws, commanded the militia, organized courts martial, and was responsible to the governor at Williamsburg, as the latter was to the Crown. The County Court was of high character. The planters in a county made a sort of Council for their commander or lieutenant. There was thus developed a sort of county sovereignty which was the forerunner of the State sovereignty of a later era. The Virginia idea of equality was not that of individual men, but of representatives; and each planter represented his subjects, black and white. Their alliance with the masses in the Revolution was not due to any fundamental change. Indeed, that was a gentlemen's revolution, and the masses went to them as their natural leaders.

Moreover, to be exact, it was the Crown that entered on a revolution. A rebellion against the English Constitution would have been impossible in Virginia. The King violated the law, and sought the alliance of Indians and negroes against their local rulers. 
The Barons allied themselves with the people, who had different grievances against the Crown,-religious, democratic, or other,but when the war was over they were again a peerage of the plantations.

Every one of those planters was a law-abiding man. Beside his Bible, if not, indeed, on top of it, he kept John Mercer's "Laws of Virginia." He was always a lawyer, and studied the English books. In customs now lawless he was strictly legal: for instance, in the single combat, now called the duel, provision for which remained in the English Code even within the present century. So, also, with the one or two uncommissioned law courts of the colony. In regions where courts have not been established, English law recognizes, as if regular, courts extemporized in emergencies, where trials are fair: such was the court of Judge James Lynch, as just a man as ever lived, whose name is now taken to shield cowardly ruffians who murder the defenceless. Nothing of that kind was known among the gentlemen who built up the power of Virginia. They were authorized to administer laws to their slaves and serfs, but they must be laws. The great outbreak of some of the gentry, a hundred years 
before the Revolution, against the government in Virginia is finding some defenders, as an honorable revolution. But it was not such; it originated in an effort to mob Indians, and to maintain the privilege of exterminating them, and was justly crushed. From that time there was little trouble between the whites and Indians, who were taught in the time of Spotswood and Gooch pretty much as they are to-day in the Indian college at Hampton, Virginia. And when, after the middle of the eighteenth century, the colony was invaded by northern Indians, those of Virginia did not take their part.

The planter on his large estate, in his luxurious mansion and park, was content, and not anxious to participate in the general government of the colony. This was especially the case with the planter on the Rappahannock. Landon Carter of Sabine Hall had to be dragged out of his retreat even in the stormy days when the Virginians seemed virtually abandoned to invaders from Canada. So it appears by a poetic epistle to him from Colonel Richard Bland (afterwards of the Continental Congress), found among our Havemeyer manuscripts. It is given here less for 
its poetic art than as a suggestive document of the time (1758):

"An Epistle to Landon Carter, Esq., upon bearing that be does not intend to stand a Candidate at the next Election of Burgesses.

"'You'l envy not, you say, Dear Sir, the great, Their Pomp, their Luxury, their pageant state,

But bless'd with all that Heav'n below can give,

A mind contented and a taste to live, You'l smile superior on their empty show, Their seeming pleasure but their real woe. At Sabine Hall, retir'd from public praise, You'l spend in learned ease your future days. Yet deign to hear a Muse, whose honest strain

Did ne'er commend the vicious nor the vain, But sometimes in the cause of Virtue soars, And scorns less merit for her Lay, than yours.

Whilst you, my friend! with pleasing joy survey

Your teeming flocks, as through the meads they stray, 


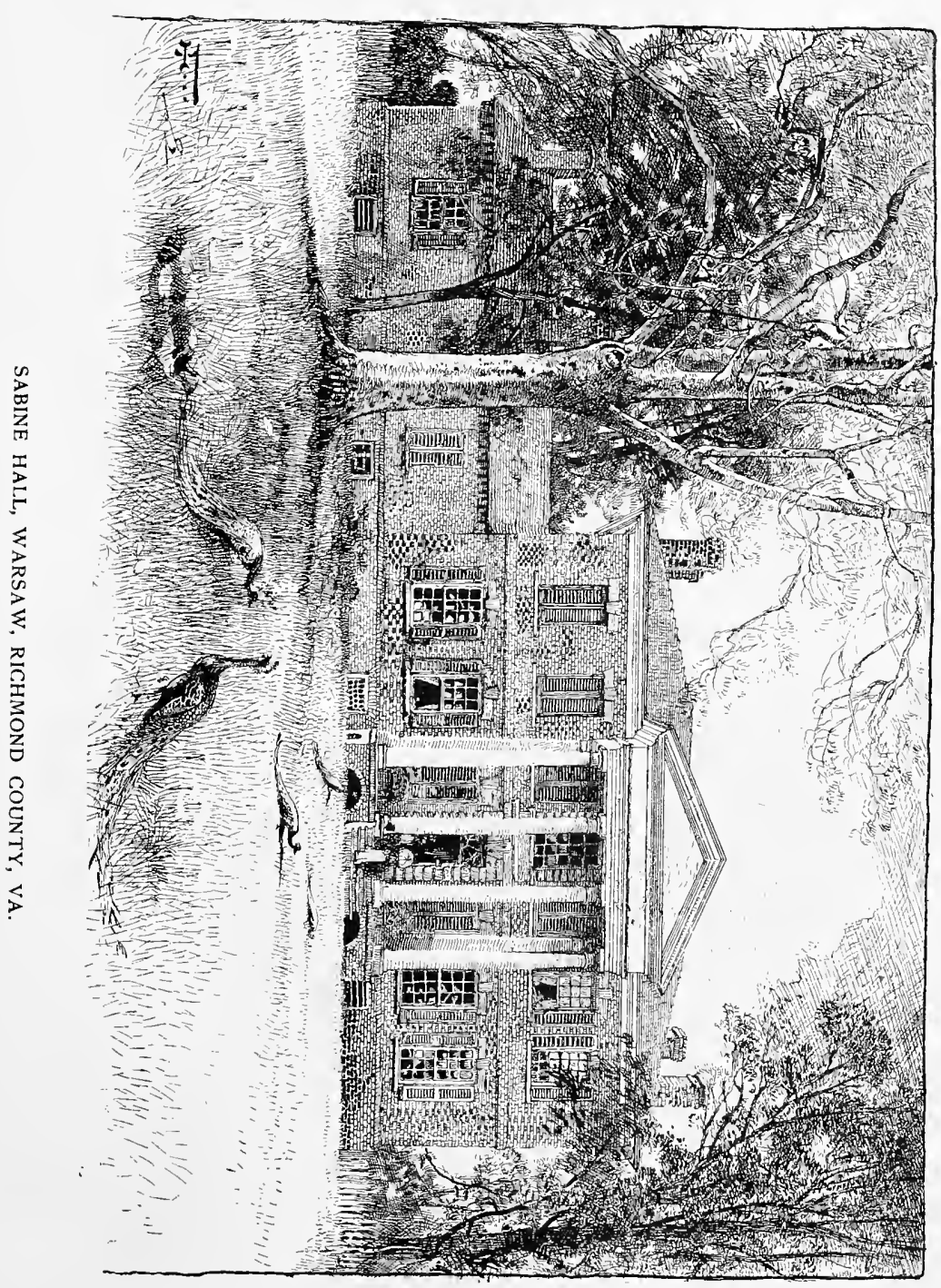



Whilst you, in Sylvian shades and pleasant groves,

Hear Philomelas chanting to their Loves ;

Whilst you, secure from all domestic strife,

Enjoy delightful scenes of rural life ;

Permit me to deplore my country's fate,

The dire misfortunes of her tot'ring state.

When Power's uplifted arm was hurling down,

With spurious show of service to the CROWN,

A mighty weight, to crush our antient Laws, And with our spoils to gorge its greedy Jaws, You then appear'd, your Country's surest Friend,

And did her Cause with manly sense defend.

But now, alas! you do not deign to hear Your Country's groans, involved in horrid War.

Canadian Wolves, a bloody, savage Band, Invade with hostile arms her virgin Land, Forsaken by her Guardian and her Friend, Who used to her the sagest councils lend, But now in fields and meadows spends his days

Recluse from public view, and scorns our praise ; 
But now the life of Tully's self is spent Supine at Rome, and carping momers sent With baleful nonsense, in the grandest Cause,

T' assist her Senate, and ordain her Laws.

Young pageant Elfs do now live pleas'd, and aim

By shocking common sense, at public fame. Agelaus self would laugh to hear such Tools, The gewgaws of the vulgar and of fools, With Midas ears, bray out with vain pretence, 'We are the men of weight and men of sense.' Rise then judicious Friend! step boldly forth, And vindicate your merit and your worth; Strike bold Pretenders, to the highest place, Into oblivion, and a just disgrace.

Yes! all ye sons of Folly and of Vice,

From whom our present Evils take their rise, Yes! all ye slaves of Luxury and Lust Avant! Begone! sink into native dust. Do not our annals with your names disgrace, Depart to your own dul and stupid race. The Country's Patriot once again appears To vindicate our Laws, and calm our fears. He'l suffer none, whilst he his Pen can wave, To be with ease and safety Fool or Knave. He'l always foremost be, and boldly rise A Friend to Virtue and a Foe to Vice. 
Then stand once more, aloud your country cries,

(Nor do her prayers nor her commands despise),

Stand once again, and save a sinking Land, Which is sincerely wish'd, by Yours D- $\mathrm{k}$

B-d."

The date of "Dick" Bland's effusion is "June 20, I758." Those who desire to follow its allusions will find an account of the period in Campbell's "History of Virginia."

The requisites of government in colonial Virginia were church, court-house, prison, pillory, stocks. The writer remembers disused stocks that fifty years ago kept their place in Falmouth just outside the graveyard, where, as I was told by Miss Lucas, in her ninety-fifth year, the old church stood. The vestries had some heresies and impieties to deal with. In Spottsylvania, Larkin Chew, magistrate, and Thomas Chew, churchwarden, appear to have been especially zealous in maintaining religious order. "Thomas Mosely and John Shelton," says Dr. Slaughter, "were committed by Larkin Chew, upon information of Thomas Chew, church-warden, for taking upon themselves to baptize the 
child of one Ann Alsop. They were required to give bond and security for their good behavior, and in default of appearing to answer at the next court, were ordered to be committed to jail, and receive thirty-one lashes on their bare backs - sixteen in the evening, and fifteen next morning. At this term of the court [ I 724] there were thirteen presentments by the grand jury of absentees from public worship. Public opinion, however, seems to have been in advance of the legislation of the times upon the rights of conscience, as it appears from the record that only one of these cases was prosecuted to execution." This case was John Digg, fined Ios., or one hundred pounds of tobacco, or in lieu thereof corporal punishment. Probably the lay baptism was intended medicinally, or as a means of liberating the child from a supposed spell of witchcraft. But the tendency of Virginians was much more towards rationalism than superstition. Deistical opinions were widely prevalent in the colony during the eighteenth century. Two professors at William and Mary College, albeit clergymen, were deists, and distributed the works of English deists among the students. Peyton Randolph probably, certainly his brother John, the King's Attorney, 
Chancellor Wythe, and Jefferson were deists, and the first bishop, Madison, was a rationalist. It was probably on account of the prevalence of rationalism at William and Mary College that the father of James Madison sent him to Princeton-an incident that influenced the political future of the State, perhaps of the nation. Yet some of these latitudinarian gentlemen were more resolute churchmen than the English at home. Peyton Randolph, while King's Attorney, contended against the dissenters that the Act of Toleration did not extend to Virginia. "Then neither does the Act of Uniformity," answered Samuel Davies, the Presbyterian apostle in Virginia, whose position was sustained in England. The Baptists were mobbed in some parts of the colony, but persecution was of a comparatively mild type in Virginia, and no life was sacrificed to bigotry. Governor Dinwiddie ordered young Colonel George Washington to lash the Quakers until they consented to help build forts, but he evaded the order. 


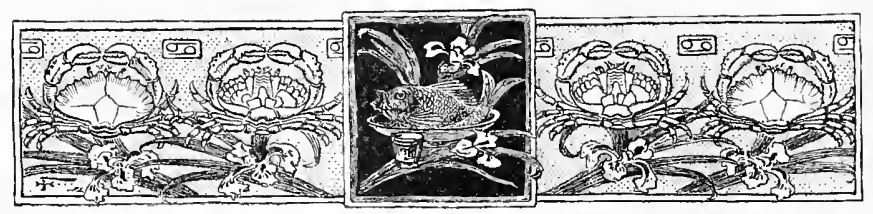

VII

\section{Warner Hall}

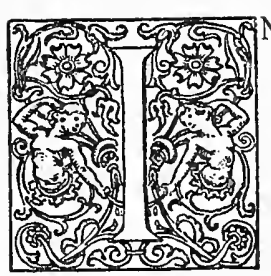

I849 Mr. Colin Clarke, of Richmond city, was residing in the superb colonial mansion known as Warner Hall. It antedated and surpassed all others as a monument of the wealth and culture which enabled transplanted scions of great English houses to produce a more glorious Gloucestershire in Virginia than any known in England. It had twenty-six rooms; its ample hall and wainscoted drawing-rooms were hung with ancestral portraits; its library was rich in early English books. It was built 
by the first of the Lewis family, who emigrated to Virginia as early, according to a family tradition, as 1635,- - having come on the ship "Blessing." Sixty years ago, or thereabout, the heirs of its founder placed Warner Hall in the market; and one of the family, Fielding Lewis, being near his end, offered to purchase it as a bequest to his son-in-law, a son of Chief Justice Marshall, or else leave him its value in money. Marshall asked him his wishes. The old gentleman said that of course he had a partiality for the place, which had come down in the family for two hundred years; but, as his advice had been asked, he would answer as a disinterested party: "Never buy an hereditary estate, for many people think they have as much right there as the owner." Marshall took his advice, and the house and homestead passed out of the family. But Mr. Colin Clarke lavished his means on Warner Hall, and kept it in good condition. Time and nature conspired with him. The sunshine of centuries had so hardened the cement that each great wall was as if built of one vast brick, and bade fair to stand until the last trump should blow it down. Yet all perished in a night by a casual breath of the owner. Mr. Clarke remarked at breakfast 
that, were it not for his love of Warner Hall, he would live all the time at Richmond. This was heard by a negro boy of some fourteen years, communicated to a female comrade of like age, to whom as to himself Richmond shone like the Golden City. Shortly after Warner Hall was a smoking ruin.

In the once beautiful park nothing is left of the old buildings but the kitchen,-abode of the piccaninnies, so fatally frantic for their Richmond Jerusalem. With its huge fireplace the kitchen remains to this day, symbol of the stone rejected by the builders of Virginia's ancient greatness, and which ultimately ground it to powder. In early times the clergy of Virginia held that the negroes, being baptized, were servants of Christ, and could not be held as slaves. Some planters contested this, and the dispute was submitted to the ecclesiastical authorities in England. These pronounced in favor of the planters, and to their decision America owes a civil war and Virginia her desolations.

It must be said, however, that Nemesis has rarely taken her disguise from the dusky race, left without share in the grandeurs they built up, and with brains too dwarfed to appreciate them. Nor can I discover an instance in 
which any old mansion or historic edifice in Virginia was destroyed by the Northern armies, though these soldiers - from the number of old papers whose disappearance is attributed to them - must have been mainly collectors. The magnificent mansion near Fredericksburg, "Mannsfield," built by Mann Page, was indeed burned during the war, but it was through some North Carolina soldiers who cooked their dinner on its inlaid floor, perhaps fancying it some kind of stone. The present Nemesis of the old mansions is another rejected power-Steam. "The Tide Water Virginian," says Dr. Archibald Taýlor, "was very conservative; he had an easy way to market, and was opposed to railroads. He said they brought strangers, extravagances, and debt. Once in a while he took a run up to town and got a bad headache from the effects of the cordial greetings of his friends, and in a melancholy mood he would say that 'he never would go to one of those damned places again.' He was a man of importance at home, especially if he lived on land he had inherited and owned slaves that had come down by inheritance from his ancestors. In Baltimore or Philadelphia he was nobody." But now the grandson of this old Baron-whose town friends gave him 
too many juleps - vainly calls for the railroad, which has gone another way. His fine old mansion is crumbling for need of repairs, and the repairers with their materials are at a costly distance. One after another the old houses come into the market; and the new owners, finding them uninhabitable, sometimes pull them down. Only lately the great Fauntleroy House on the Rappahannock was taken down for the value of its bricks, by an owner who probably never heard of the daring Moore Fauntleroy, nor of Betsy the "Lowland Beauty," for whom George Washington sighed in vain. A precisely similar fate-sale of its bricks - has also just overtaken "Eltham," where Washington did not sigh in vain; for probably the Bassett family tradition is right, that it was there, in the house of her sister, wife of Burwell Bassett, that the widow Custis consoled him for the "cruel sentence" of Betsy Fauntleroy.

The number of old mansions that survived the flames of civil war but were burnt after peace came, is large enough to be suspicious. Berkeley, Shirley, and Brandon on the James, Sabine Hall, Mount Airey, and one or two other places on the Rappahannock, are still kept up by descendants of those who built them; and 
"Rosewell" is still the glory of Gloucester, under the care of Judge Fielding Lewis Taylor. But such estates and homes are maintained with difficulty in their hardly accessible regions, and the very sentiment that has kept them is in many cases anxious to part with them to wealthy outsiders who would support their ancient dignity.

Warner Hall was a picturesque frontispiece of all family history in Virginia. It was associated with the foundation of families who largely created historic Virginia, and who, distributing themselves first along the Potomack and the Rappahannock, contributed pioneers to every part of the south and west. With Warner Hall were especially connected the earlier ancestors of George Washington. Twentytwo years before Colonel John Washington is mentioned in the annals of Virginia, appeared the Hon. George Reade, grandfather of Washington's grandmother, from whom probably came his name "George." George Reade, brother of Robert, an official of the English State Office (temp. Charles I.), came to Virginia on Government business in 1637. He resided with the governor (Harvey) for a time, was made secretary of the colony (1640-1), was afterwards twice elected Burgess for 
James City, and was a member of the Royal Council (1657-60). His daughter Mildred married the famous Colonel Augustine Warner, who had inherited from his father, an English officer, 2500 acres at Kiskiack, on the Pianketank River. From this gentleman the name "Augustine" may have come into the Washington family.

Colonel Augustine Warner had a brilliant though brief career. After graduation at Cambridge, England, he was at once chosen Burgess for Gloucester County, and in 1666, his twenty-fourth year, was made a member of Council, Sir William Berkeley being then governor. Ten years later he was Speaker of the House of Burgesses, the office next in importance to that of the governor. Speaker Warner it was who received the submission of Bacon, the rebel leader, who, when resuming his war with the Government, was careful to fix his headquarters at Warner Hall,- which was not, however, the Speaker's residence. Speaker Warner died in 1681. His portrait at "Rosewell," residence of Judge Fielding Lewis Taylor, is that of a most noble and refined gentleman. From members of his family are descended various branches of the Nelsons, Peytons, Madisons, and Taliaferros. His sis- 
ter Mary married Colonel Townley, and from them were descended "Light-Horse Harry" and General Robert E. Lee. His daughter Mildred married Lawrence, the grandfather of George Washington.

But the great family with which the Warners were connected was that of Lewis, the Washingtons of the seventeenth century being by no means of equal education, rank, or wealth. The story of the Lewis family has never been published, and it is too long to be told here; but a few facts from it will enhance the interest of the Lewis letters presently given. The first Virginian of the name was General Robert Lewis, son of Sir Edward, of Brecon, Wales, - said to be descended from an Earl of Dorset. The building of the mansion afterwards called Warner Hall is attributed to this Gen. Robert Lewis, who, in 1650 , received a grant of 33,333 $1 / 3$ acres in Gloucester. His son John married Isabella Warner, a sister of the famous Speaker, and in her honor Warner Hall was named. According to another tradition, however, it was this John Lewis [1st] who built Warner Hall; and it is added that his wife was the daughter of a rich East Indian merchant, whom he married in England. Their son, John Lewis [2d], mar20 
ried Speaker Warner's youngest daughter, Elizabeth. A son of these, John Lewis [3d] (whose letter is printed in this chapter), married Frances Fielding (as is supposed); another son, Robert, married Jane Merriwether ; a third son, Charles, married Mary Howell. The family tradition is that their Fieldings are descended from Lord Fielding, Earl of Denbigh.

The coat of arms of the Lewis family of Gloucester is, perhaps, the most extensive and curious in this country. It contains twelve shields. The device of the Lewis family proper is a dragon's head holding in its mouth a red hand. This has the chief place on the shield, and it also surmounts the helmet as crest. "Curious stories," says Millington, "have been invented by unheraldic writers, to account for the appearance of the 'bloody hand' in a baronet's coat-of-arms. It has even been supposed to be a mark, not of honour, but of infamy, perpetuating the memory of some fearful act of revenge or cruelty by ancestors of such families as bear it. It was added, that on one condition only might it be expunged from the coat,- - that the bearer should consent to pass seven solitary years, unshaven, and without speaking, in a cave; but the truth is, that the hand formed part of the arms of the province 
of Ulster, and commemorates the daring of a bold adventurer, who had vowed to be the first to touch the shore of Ireland, and, finding his boat left behind, cut off his hand, and flung it before him to accomplish, in this literal manner, his vow. James I. conferred this badge on the Order of English Baronets, as being Knights of Ulster, the defence and colonization of that province being the ostensible reason of their creation." Next to this on the Lewis shield is a chevron between three spearheads, or. (golden), engrailed,-arms of Lewis of Van. The ancestors of this family are traditionally said to have been lords in East Glamorgan, and the chief of those who claimed descent from Gwaethored, Prince of Cardigan. The Lewis ancestor was the representative of Teon, of the lineage of the Princes of Britain, and the first Bishop of Caerleon. Later heralds have invested him with three Eastern crowns for armorial bearings. The tenth or eleventh in descent was Golydobun, Lord of Caerleon (wife Morfydd), whose emblem is third on the Lewis shield,-a silver lion rampant, sable ground. It is noticeable that this lion appears on the shield of a branch of the Howell family in Wales,-Howell ap Griffith,- though the arms of Howell, Prince 
of Caerleon, were gules three triple-topped towers. The latter were the arms of Mary Howell, who married Charles Lewis of Virginia, and occupy the fourth place on the Lewis shield. The fifth place is assigned to the arms of Jones, Breconshire,- - vert a chevron between three wolf-heads erased, or. The sixth device is that of the Bruce family,-argent, three chevronels, gules. Connection with the house of Courtenay is indicated by their three torteaux, - that is, cakes or tarts (Italian torta). We find, of course, the Washington arms, and in the old manuscript which I am using (lent me by Captain Henry Howell Lewis) it is said: "Sir Stephen de Wessington at the tournament of Dunstable, 1327, bore for arms argent 2 bars gules, in chief 3 mullets pierced." At the bottom of the shield are the Fielding arms,- - argent on a fesse azure three golden mascles or lozenges ; the Warner arms, - vert a cross engrailed, azure; the Dangerfield cinquefoil, or. within a bordure az. bezantée. In the centre of the shield, concealing one of the Jones wolf-heads, is the shield of pretence,-in chief three heads (that look like boars, but may be the Gooch talbots), and three covered cups, arms of the Bowles family. The wife of Colonel Warner 
Lewis was a Bowles of Maryland, though she had previously married the son of Sir William Gooch. "Where the wife," says Millington, "is an heiress, even in expectation, her arms are borne upon an escutcheon of pretence, or surtout, but the children bear their parents' arms quarterly." The Bowles arms, surtout - over all-show that Colonel Warner Lewis had married an heiress in the widow of the Honorable William Gooch.

It is notable that the three covered cups, with covers more pronounced, are found in Brington Church, near Northampton, England, combined with the Washington arms, on the tomb of Lawrence Washington, greatgreat-great-grandfather of the general. The cups there represent the said Lawrence's wife, Margaret Butler. As there was a great Butler family in Westmoreland, Virginia, one of whom was the first wife of Captain Augustine Washington, it would be interesting to know whether through them the three cups reached the shield of the Bowles family of Maryland and Virginia.

The Lewis motto, Omne solum forti patria est ("Every land is a brave man's country"), seems to be a modern condensation of Patria est ubicunque vir fortis sedem elegerit ("A 
brave man's country is wherever he chooses his abode"), attributed to Quintus Curtius Rufus. It is the forerunner of Thomas Paine's motto, "The world is my country."

The Lewis pedigree is complicated by the fact that another Lewis came from Wales (1692) and founded a powerful family in King and Queen County, Virginia. In this line, also, the name Howell appears. The name of this immigrant was Zachary Lewis ; his son, of the same name, was the great lawyer at Fredericksburg in its first years, and one of his daughters married Chancellor Wythe. One of his descendants was John Lewis, of "Llangollen," Virginia, and afterwards of Kentucky, a celebrated classical teacher and author of several works - among them "Young Kate, or the Rescue : a Tale of the Great Kanawha," which contains graphic descriptions of several parts of Virginia. (It was published by Messrs. Harper in 1845.) Besides these two families founded by immigrants from Wales, there was yet another of the same race who came from the north of Ireland. According to a manuscript of John Lewis of "Llangollen" (Hayden, p. 379), this immigrant's name was John. He married the daughter of a Scotch laird, settled in Ireland, was attacked by an Irish lord, 
killed him, fled to Virginia, and was father of the famous settlers of Augusta County, in that State,-Thomas, William, Andrew, and Charles. The descendants of these three Lewis families have intermarried from time to time, and have never been able to settle among themselves their ancestral belongings. Without entangling my reader in these discussions, I may say that the Lewises of Warner Hall have a fairly traceable lineage - that given in this chapter.

There are many instances in Virginia of the immigration of families related to each other in England, but drifting apart amid the exigencies of colonial life until their relationship was lost sight of. The marriage of Mary Howell (I 717) to Charles Lewis, of "The Bird," Albemarle County, seems to have been regarded by the Lewises as the way in which their favorite name, Howell, entered the family. No doubt a good many of Mary (Howell) Lewis's descendants have borne the name, but Hayden ("Virginia Genealogies," p. 380) finds in a "List of the Nobility and Gentry of England and Wales, 1673," the name "Howel Lewis of Gwredog, Esq., Angleseyshire." In Virginia, John Howell appears as a patentee of land in Henrico County, in 1639. There are grants, also, to 


\section{BARONS OF THE POTOMACK}

Lieutenant John, William, and Rebecca Howell, found by Mr. Brock, in Henrico, Elizabeth City, Northumberland, New Kent, Nansemond, Isle of Wight, Brunswick, and Amherst counties. I am told that the Hon. Howell Cobb of Georgia traced his descent from Mary Howell Lewis; but one Howell Cobb had a patent in Lower Norfolk County in 1638. There are preserved in the Lewis family portraits of "Sir John and Lady Howell," who have not been identified with any of the above-named patentees. Unless the "Sir" be a traditional title, it may be that they were the parents of Mary, and that Charles Lewis married her in Wales; for the Gloucester Lewises were ship-owners, were educated in English universities, and several of them were received at court. The portrait of Mary Howell in her sixteenth year is evidently the work of some European artist. It could not have been painted in any American colony at that time, nor could the portraits of the "Sir John and Lady Howell" mentioned. Twenty-five years after Mary's marriage, or in 1742, John Lewis, as we shall see, mentions a Miss Howell's engagement to William Lightfoot, which suggests a Howell family of high position in Virginia; but whether Mary belonged to it is 


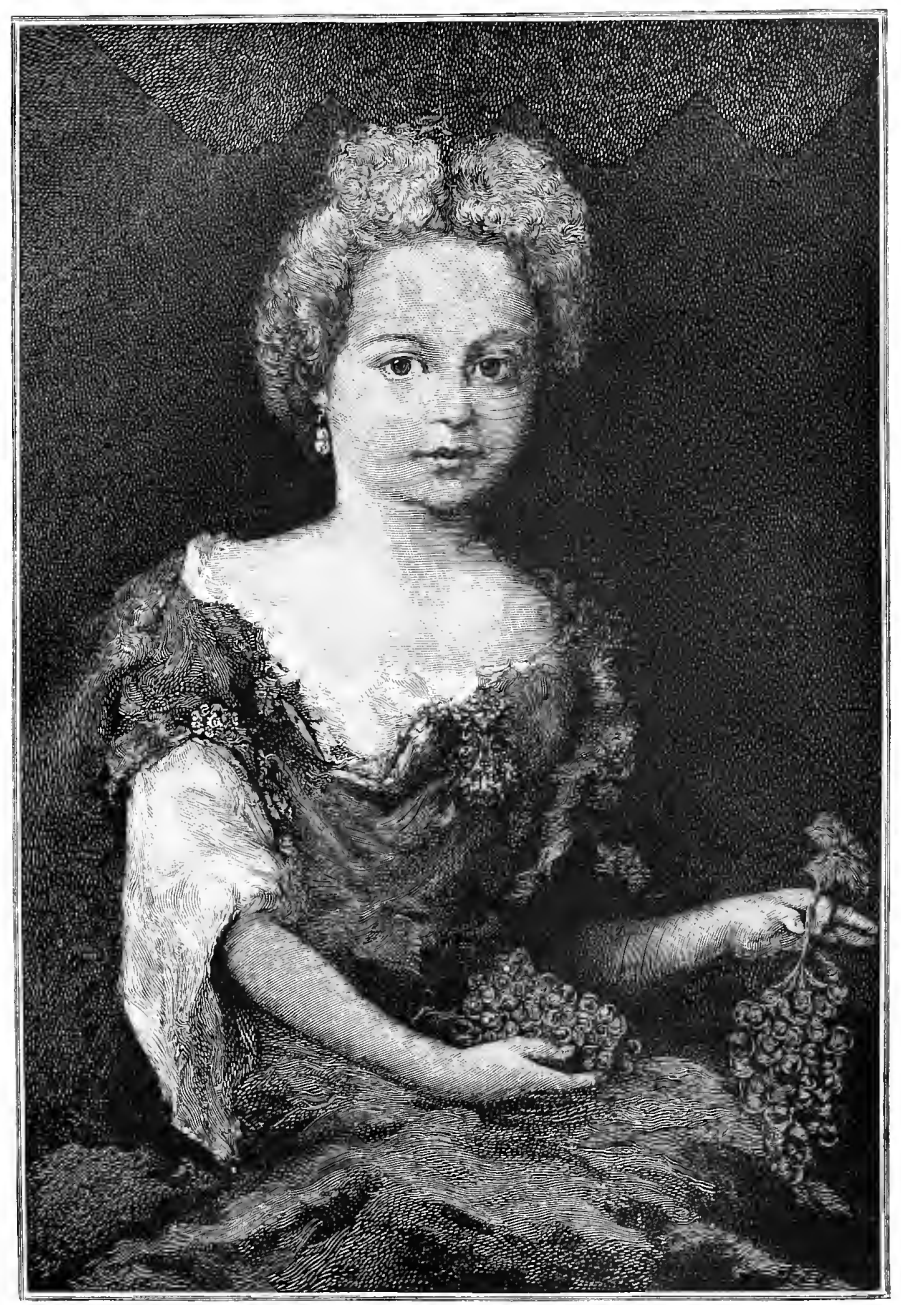

MARY HOWELL. 


\section{,}


doubtful. The wife of Charles Lewis was held in highest honor by the Lewis family, who impaled her three towers or castles, arms of the princely house of Howell in Wales. She must have been a person of fine characteristics for the traditions concerning her to last, as they do, to this day. Miss Douthat, of Botetourt County, Virginia, has the original portrait of Mary Howell, of which there is an excellent copy in New York, belonging to another of her descendants, Mr. Coleman G. Williams. She is a quaint little lady, perhaps in her sixteenth year, and richly dressed in silk, with pearl necklace. Her golden hair is abundant and the eyes expressive. It may be mentioned that Robert Lewis, a brother of Charles, was grandfather of Merriwether Lewis, of the Lewis and Clarke exploring expedition, a sketch of whom was written by Thomas Jefferson.

The above John Lewis [3 d] inherited Warner Hall. His wife, Frances Fielding, died in 1731 , and Col. John, a councilor, devoted himself to public affairs. It was a custom of the time to honor the mother's name in the second son; in this case Col. Fielding Lewis, with whom the name first appears in the family. The lady's first name was also honored, two of 
her sons having so named their eldest daughters. The eldest son, Warner, who inherited Warner Hall, married the widow Gooch, as we have seen. The portrait of Eleanor (Bowles) Gooch, a fine painting of a beautiful woman, hangs beside that of her husband, Warner Lewis, at "Belle Farm," the only old house left on the great Lewis land grant in Gloucester. (Their great-great-grandson, Judge Fielding Lewis Taylor, resides at "Rosewell," Mrs. Taylor [née Deans] being a descendant of the Dandridge family.) The second son of John Lewis [3d] was Colonel Fielding, who married, first, Katharine Washington, first cousin of the general; and, secondly, Betty, the general's sister. The third son of John Lewis [3d] was Charles, who married Mary Randolph, according to a disputed statement, and found a second wife in Lucy Taliaferro. This youngest son, Charles, was a captain under Washington in the expedition against the French, 1755 , and his valuable journal of that march has just been published by the Virginia Historical Society, from the original in possession of his grandson, Thomas Waring Lewis, of "Mansfield," Caroline County.

Hitherto it has been known of John [3d] that he was a member of the Royal Council in Vir- 
ginia, and that he was the owner of Warner Hall until his death (Nov., I745). But my reader will have the pleasure of meeting him personally in his seventy-third year, in the lively letter here printed. It was written to Major Lawrence Washington, just after the Cartagena troubles, and no doubt made him homesick enough. The letter is addressed: "To Capt. Lawrence Washington, of the American Forces. P. Capt. Briggs. At Jamaica."

"Capt. Lawrence Washington.

"VIRGINIA, June 28th, 1742.

"Dear Sir,

"Having this opportunity by a Vessel of our own, John Briggs Master, consigned to Capt. Robert Turner by the advice of our good Governor [Gooch], I could not let it pass without letting you know that we are well, and much as you left us. My son Warner is come from England, and I have taken him into partnership by giving him half of all my vessels and cargoes. Your brother Augustine is just now come inn [from Appleby School, England] and is gone up to his father [near Fredericksburg]. I have not seen him, but I hear he is very desirous of being with you. Mr. Page is married to Miss Alice Grymes, and Mr. 
Willis will soon be so to Miss Betty Carter. Miss Howell I believe partly engaged to $\mathrm{Mr}$. Wm. Lightfoot. Mr. Moore, Mr. Baylor, Mr. Grymes, Mr. Burwell, and all the young gentlemen and ladys of any note are yet single, and like to be so as far as 1 know. Mr. Thomas Nelson is come in and gone to make his addresses to Miss Lucy Armistead, and generally thought it will be a match. Mr. Wormely and Colo Charles Carter has lost their Ladys. Mr. Wormely is making his addresses to Miss Bowles of Maryland; how it may fare with him I cannot say. The poor Secretary is near his death with a dropsy. The Governor has not yet recovered his health, or do I think he ever will perfectly. Our Assembly is now broke up, but has done nothing material besides continuing the Tobacco Law for four years longer. All your friends and acquaintances are very well. Miss Randolph is yet single, though many offers has been made her; it is reported by some that she stays for you, but not believed by many, for the danger of war and a sickly climate no person can depend upon. I pray God give you a safe delivery from them.

"And now I have given you as plain and short a detail of the affairs of this part of the world as possibly I can, time not admiting me 
to be more full, the vessel waiting for my dispatch.

"If these should meet with you at Jamaica and there is anything in our poor Cargoe that may be acceptable to you I have given the Capt orders to let you have it Gratis. I should be very glad of a line from you giving me as short and full account of the affairs with you as I have done here. We have no news that can be depended upon from England a great while. I can only say that I hope they will be in earnest now, for I think they have only been at play hitherto with the lives and fortunes of thousands of poor souls. I cannot see what delight you can take in such a life. I heartily wish you safe here with Honour, that so wished for title, so much desir'd to be gaind in the field of Battle; but I think may as deservedly be acquir'd at home in the service of his Country, County, Parish and neighbourhood, in Peace and Quietness.

"I am Dear Sr

"Your most affecte Kindsman "JNo LEWIS."

It is rare indeed to get from the olden time so much entertaining and useful gossip as the above letter contains. It may have been writ- 
ten from Warner Hall, but more probably from Williamsburg, as it is apparently written just after a consultation with the governor. Augustine (Austin) Washington might have landed at either place, on his return from England, and in a social sense they were one neighborhood. The Mr. Page who married Alice Grymes (Ist wife) was Mann Page of Rosewell. William Lightfoot did marry Miss Howell, who by him was beaten, so that she left him. Henry Willis, son of Col. Henry, founder of Fredericksburg, by his first wife (General Washington's cousin), is probably the gentleman mentioned as betrothed to Miss Betty Carter. And this young lady is probably the same as the "Elizabeth Carter, I 4 years old," whose outfit for her first season (1739) is given on our page 121. She was "King Carter's" granddaughter, and apparently ward of John Lewis, who ordered the outfit, and now reports the execution done on the heart of his relative from Fredericksburg. Lucy Armistead, to whom Thomas Nelson, uncle of the famous general and governor (then four years old), paid his addresses, was one of the great Darmstadt family. They called their mansion, after the country from which they emigrated, "Hesse," 
but changed their name to Armistead. Ralph Wormeley, who had "lost his lady" (Sarah, daughter of Col. Edmund Berkeley), succeeded in his suit for the hand of Miss Bowles (Jane, daughter of Geoffrey Bowles), became a famous member of Council, and stood by his oath of loyalty at cost of his home and happiness. His wife, Jane Bowles, was a near relative of the widow Gooch (née Bowles), who married Warner Lewis, son of John, whose letter we are considering. The "poor Secretary" alluded to was presumably James Blair, D. D. He had acted as lieutenant-governor during the absence of Sir William Gooch on the Cartagena expedition. The last act performed by Blair as governor was on July 25 , 1741 ; so we may assume that the "good Governor" returned to his post about that time, but broken in health.

It is doubtful whether it was not at Cartagena that Lawrence Washington's constitution also received its death-blow. "Miss Randolph" - probably Mary Randolph, who some say married Charles Lewis, son of John, who writes the letter-did not stay for the captain, it may be hoped. And, by the way, this letter of John Lewis shows that Captain Lawrence Washington's name was not yet connected in 
the family with Ann Fairfax, whom he married a year later. That the health of Lawrence was feeble appears by a letter to him from Warner Lewis, which may suitably follow that of his father. It was written while he was on a visit to his relatives at Fredericksburg,- - the Willises of Willis Hill, known to recent history as Marye's Heights. Gloucester County was the original seat of the Willis family in Virginia. (Waters's "Genealogical Gleanings in England," III., p. 239.)

"Fredericksburg, April the 26th, 1747. "Dear Sir,

"You remember when I saw you at this place how much distress'd I was for Horses, and after continuing near a week in that manner was forced to put up with borrowed ones to Pageland; and after inquiring the true distance between us found it was impossible for our Naggs to hold out so far as your House, where I shou'd most certainly have been, had we not been so unfortunate losing our Horses, but it was impracticable as things have fallen out. If I shou'd not see you before I sail (wch will be in June) and there shou'd be anything in England that I can be of servis to you in, I will with pleasure do it. I shou'd be glad 
to see you at Bath, being well convinced within myself that nothing wou'd be more beneficial to your health; and if you continue in that declining state the sooner you go the better, as probably that must be the consequence one time or other, tho' 'twou'd give me great pleasure to hear that you did well without being to so great inconveniency. My compliments to your Lady concludes me, Sir, "Yours most sincerely, "WARNER LEWIS."

The superscription on this letter is "To Majr Lawrence Washington, in Fairfax Coty." Beneath it (on the back): "Mrs. Willis desires you will not send for her till after the June Fair." (This fair was the great social event of northern Virginia.) The "Bath" alluded to was the Berkeley Springs, in which the invalids of the time had such childlike faith that they would sometimes dwell there in tents, catching their death in the endeavor to end their ailments. The name "Pageland" was popularly assigned to 8000 acres owned by the Pages in Frederick County, also to 1000 acres of theirs in Prince William, the latter being on the way from the lower country to Fairfax. 
Among our letters there is another from Warner Lewis, which, though of much later date than the others, may be included here. It is addressed to Col. Landon Carter of Sabine Hall, and dated September 18, 1765.

"My dear Sir,- This will be delivered to you by my nephew Will. Armistead, who informs me that you are acquainted with his errand, which I hope meets with your approbation. I heartily wish my God Daughter Molly may like him, if she does the sooner they are married the better. The house at Hesse is at present free from inhabitants by the young Codds succeeding with our old acquaintance the $\mathrm{w}-\mathrm{d}-\mathrm{w}$. It will give me great pleasure to see Miss Molly mistress of it. Armistead is a prudent young man, very good natured, and I am sure will make her happy. You have been young yourself, for God's sake hurry on the match if no objections; it will be to their mutual advantage to be soon settled, and I hope once in my life I may have a chance to spend a merry hour with you and your niece on the banks of the Pianketank. I am Dr Sir,

"Yrs most sincerely, "WARNER LEWIS." 
This letter is endorsed by Col. Carter: "Col. Warner Lewis." William Armistead was the heir of "Hesse," already alluded to, on the Pianketank, and probably the nephew of Mrs. Warner Lewis (née Bowles).

Dr. Archibald Taylor, a great-grandson of Warner Lewis, says that as the Revolution drew nigh, the old gentleman said "he saw that the separation from England was irresistible, sooner or later, but he hoped the connection would have lasted his time; his boys might do as they pleased, he would remain at his home, Warner Hall, and take sides with neither party; he was too old to change." All of his "boys" espoused independence with ardor, as also did his younger brothers. But the Revolution had an effect on many of the baronial estates much like that of the civil war on those of a century later. A glimpse of the later time is gained in the following letter of Warner Lewis [2d] concerning Warner Lewis [3d], dated "Warner Hall, Sunday, January 2, 1791." It is sent me by Mrs. Payne, of Hopkinsville, Kentucky.

"Warner goes to Williamsburg, my dear Becky, to collect his movables, and to transport them to York in the cart you mean to 
send for your pork, which will lighten the expense to you and be an accommodation to me.

"He is now come to that time of life when if he is disposed to study he can as well do it here as in Williamsburg; and if he will not build up on the foundation he has lain, or ought to have lain, the loss will be all his own. To me his stock of knowledge appears to be very slender considering the happy opportunities he has had of acquiring improvement, and the sums that have been paid to tutors for this purpose. I was anxious to give him a profession that might aid the small inheritance he will have, and I confess I had it very much at heart that he should acquire some fame as well as profit from the exercise of that profession; but 1 fear my aims and expectations will be mortifyingly disappointed unless there should be a greater change in him than I can flatter myself with.

"Give my love to Betsy if you please, and tell her that both my head and hand are so much affected as to render writing very painful, which must be my apology for not answering her letter. I am, my dear Becky, most affectionately yours,

"WARNER LEWIS." 
The writer of the above letter had been educated at Oxford, and presented at court before returning to America, where he did valiant service in the Revolution and earned the friendship of Washington. It was written to his sister Rebecca, who married Dr. Robert Innes, brother of the attorney-general. Although the third Warner does not appear to have been up to the high standard of culture in Warner Hall, the family reared in that place has to-day many eminent representatives in the West and South. A family tree is known by its fruits; and, so judged, there are few in America more sturdy or more worthy than that whose root was planted in Warner Hall.

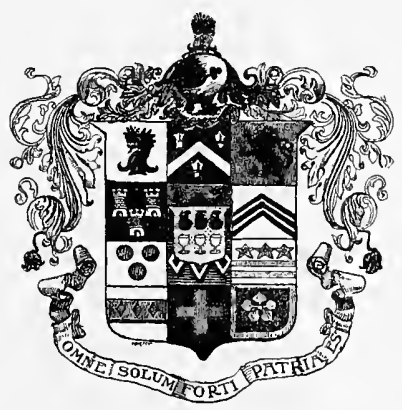




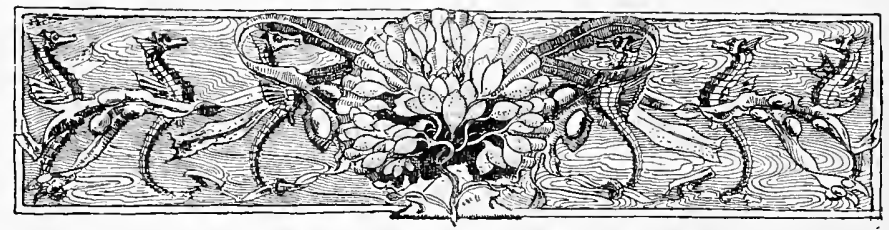

VIII

Word-fossils and Folk-lore

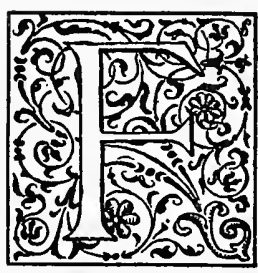

years ago the early oysterboat was an institution of the Rappahannock. About sunrise in every town and village on the river, black servants with tin buckets and white lads with capacious mouths flocked to the moorings where the negro oystermen dispensed the breakfast supplies and gave casual morsels on the half-shell to the watering palates around. They were called Carter Creek oysters. The name may be inexact; but they came from the lower Rappahannock, and chiefly, I believe, from beds cultivated by old "King Carter" of 
Corotoman. His name added an aristocratic and historical flavor to the delicious bivalve, which in turn preserved in pleasant associations the memory of much-abused Robin. For the man who exacted rents for Lord Fairfax and for his own hundred thousand acres could not be popular. On his tomb in Corotoman Church, which he built, was chalked :

"Here lies Robin, but not Robin Hood, Here lies Robin that never was good, Here lies Robin that God has forsaken, Here lies Robin the Devil has taken."

But the memory of Robert Carter, who took his place as successor to the Rappahannock kings, survived all lampoons. Every Virginia family is proud to impale his cart-wheels vert, which should have quartered three Carter oysters argent,- the oldest family being parvenu beside these natives. Even from the gastronomic point of view, it is a fair earthly immortality for any name to be connected with the finest of oysters; but the Rappahannock bivalve has larger claims to respect. It may be justly associated with tobacco as a factor of American history. It was the great oyster-beds that determined both the aborigi- 
nal and English settlements of the Rappahannock. They caused the sojourn there of Capt. John Smith; he and his men carried these oysters in bottles, and were supported by them in making their explorations, which resulted in friendly treaties with the natives. To the feast of oysters and tobacco the Englishmen added rum, and the civilities began which ended in civilization. The "eightie who lived upon Oysters in June and July," as the chronicle relates, were pioneers of the multitudes whom that prolific fishery attracted, as well as the opportunities of trade with the Indians previously attracted by the same. There was thus built up gradually a Rappahannock commonwealth which steadily developed a certain independence of the authority established on the James. In the Revolution there was not one Tory known on the Rappahannock. Its ancient and proud Barons all threw themselves into the cause of independence.

George Fitzhugh, of Port Royal, writing in De Bow's "Review" (April, 1859), says: "A few miles below [Port Royal] a silver medal, appearing by the inscription to have been presented by Captain Smith to Powhatan, was picked up some twenty years since. At Port Tobago, once the property of Sir Thomas 
Lunsford, there was also an Indian village. Many Indian relics have been disinterred or found lying on the ground there. We presume these Indians belonged to the tribe of Mattapoisi. Descendants of that tribe, mixed with the negro, still dwell in our neighborhood. We do not believe any Indian tribe ever resided permanently above Port Royal [i.e., on the Rappahannock]. There was no good fishing above, no oysters, and the stiff and stony lands twenty miles above could not be cultivated by their wooden or stone implements."

In the neighborhood of Falmouth and Fredericksburg Captain Smith encountered some stony-hearted tribes of the stony lands, but on the lower river oysters and pipes had made the Indians comfortable and conciliatory, as the same luxuries were said in after time to soften the backbone of many a Washington politician. On the lower river the early friendliness is preserved in the larger retention of Indian names, not only for villages but residences - as Corotoman and Moratico. The latter name is a corruption of Moraughticund, a king mentioned by Smith, between whom and "Rapahanock" there was a quarrel about abducted squaws, which the English captain 


\section{BARONS OF THE POTOMACK}

terminated. "The three women were brought our Captaine; to each he gave a chayne of Beads; and then causing Moraughticund, Mosco, and Rapahanock stand before him, bid Rapahanock take her he loved best, and Moraughticund chuse next, and to. Mosco he gave the third. Upon this away went their Canowes over the water to fetch their venison, and all the provision they could, and they that wanted Boats swam over the river: the darke commanded us then to rest. The next day there was of men, women, and children, as we conjectured, six or seven hundred, dauncing and singing, and not a Bow or Arrow seene amongst them. Mosco changed his name to Uttasantasough, which we interpret Stranger, for so they call us. All promising ever to be our friends, and to plant Corne purposely for us; and we to provide hatchets, beads, and copper for them, we departed, giving them a volley of shot, and they us as loud shouts and cryes as their strengths could utter."

So did the seventeenth century open on the Rappahannock. We may compare this earliest festival of whites and Indians with one that took place eighty years later, or in I688-easily imagined from the following 
entry, for a copy of which I am indebted to the clerk of Essex County,- - Rappahannock County lying then on both sides of the river:

"At a Court held for Rappahannock County, the 2 day of January Ano Dom: i688. Present : Colnll Jno. Stone, Capt. Geo. Taylor, Capt. Samll Blomfield,-Justices.

"It having pleased Almighty God to bless his Royall Majesty with the birth of a son and his subjects with a Prince of Wales, and for as much as his Excellency hath sett apart the 16 th day of this inst. Janry. for solemnizing the same, To the end therefore that it may be don with all the expression of Joy this county is capable of, This Court have ordered that Capt. Geo. Taylor do provide and bring to the North side Court House for this County as much Rum or other strong Liquor with sugar proportionable as shall amount to six thousand five hundred pounds of Tobacco to be distributed amongst the Troops of horse, compa of foot, and other persons that shall be present at the solemnitie, And that the said sum be allowed him at the next laying of the levy, as also that Capt. Samll Blomfield provide and bring to the South side Court House for this County as much 
Rum or other strong Liquor with sugar proportionable as shall amount to three thousand five hundred pounds of Tobacco, to be distributed as above at the South side Court House, and the said sum to be allowed him at the next laying of the levy."

The reason why the "solemnitie" required nearly double as much rum on the north side of the river was because of the larger number of Indians there. In Smith's map there are thirty-four Indian settlements on the north side of the Rappahannock, and only nine on the south side.

While the Indians were thus made royally drunk, royalty was in sore straits. Before the year was out the baby prince, welcomed in Virginia with rum "solemnities," had become a Pretender. William and Mary advanced to try and give the poor Indians something better than rum, but the colony did not distribute any strong liquors on their account. It had suffered much under the Stuarts, yet so obstinate was its loyalty to them that only in April, I689, and after repeated commands from the Privy Council, were William and Mary proclaimed Lord and Lady of Virginia. In all the history of Virginia there is visible 
this loyal enthusiasm, clinging at every crisis to the old order, while New World necessities were steadily undermining it. Throughout the country the colonists generally named their homes with affectionate recollection of ancestral associations, - as Epping Forest, Stratford, Bedford, Tusculum, Epsom, Windsor, Snowden, Llangollen, Ellerslie, Carmora, Salvington, Gunston, Iselham, Inglewood, Glencairn, Boscobel, Landsdown, Chatham, Marlborough. They had begun by founding cities in honor of their kings and princes,James City, Elizabeth City, Charles City, City of Henricus (Henricopolis). Hardly a vestige of any one of them remained in the second generation, and some were never built. Bancroft was so lost in searching after them that he supposed Henricopolis to have occupied the site of the present city of Richmond, whereas it was near the Appomattox, on Farrar's lsland, as the peninsula (afterwards Cox's) was then called. Tobacco issued a "Counterblaste" more potent than that of King James against itself, and before it fell James City. Even so fell Henricopolis. Sir Thomas Dale built forts there with names both loyal and pious-Elizabeth, Charity, $\mathrm{Pa}$ tience, and Mount Malady for the sick. The 
plantation he called "Hope in Faith." But not all this combination of piety and powder could resist the siege of Tobacco, which commanded that there should be no city life in Virginia for a time, but plantation life. So the "city" had to survive in county names. The City of Henricus preserves, not its polis, but only an abutment of it in the terminal "o" of Henrico County.

In the early days of the American Revolution a perfervid member of the Virginia Assembly proposed to change all county names that savored of monarchy,- - such as King George, King and Queen, Prince William. So fiercely did this patriotic purist anathematize royal names that he was challenged to mortal combat by a fellow-member named King. The duel did not come off, and the motion to abolish royal nomenclature retreated under ridicule. Fortunately most of the old names, in whose succession the annals of Virginia are largely recorded, remain. Many of the local names have indeed been overlaid, and some survive only in fragments. "Hampton" inadequately honors the Earl of Southampton,- Shakespeare's friend, Virginia's friend, - whose name was given to the river. The Indian School at Hampton 
might well set up some memorial of the fact that the place was named after a nobleman under whose presidency the Virginia Company, in 1621 , set apart a thousand acres for the foundation of a "Free School" in Virginia. The old Indian names have suffered more corruption. The venerable Kiskiack Church near Yorktown is now "Cheesecake," and on the James River Monacan has turned to Manakin. But some of these modifications are not mere corruptions, and indeed have instructive significance. Two of the most famous names - Potomack and Aquia - seem to have been modified by Europeans who had some memory

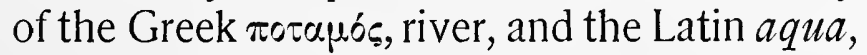
water. The latter seems to have been formed from "Quiyough," a king or tribe near the creek. In Captain Smith's map we find "Patawomeck." The Indian name of the upper Potomack was Cohongoruton, and it is so named in the Act of 1738 defining Frederick County. The south branch of the river was called Wappatomaka. In his early land grants Lord Fairfax used the names Potowmack and Wappatomack, and Cohongoruton disappeared.

In the last century a wayfarer appeared in some of the Virginia villages and was hospi- 
tably received, on the strength of a note he bore in the following words:

"The historian and philosopher Volney needs no recommendation from-G. WASHINGTON."

Could Volney return, he might find in Virginia materials for a new volume of "Ruins," and they would consist largely of the brandnew houses and modern military names under which the Past is largely buried. Such, however, is the inevitable process of historic stratification. The earlier names become fossils, and have to be dug out by the antiquarian. The old mansion opposite Fredericksburg belonged to Mr. Lacy when the Civil War broke out, and the Army of the Potomack christened it "Lacy's"; but its real name, "Chatham," had previously replaced some earlier name now lost. The "Washington Farm" near by had overlaid "Ferry Farm," which tells where the ferry plied before the Rappahannock was bridged; and the latter name had replaced "Pine Grove," which attested the forest that once grew on fields now bare. "Marye's Heights," so memorable in the Civil War, replaced its previous name 
"Brompton," as that had overlaid "Willis's Hill," which long preserved the memory of Colonel Henry Willis, founder of Fredericksburg, in the name of which town, and its streets, - Princess Ann, Charles, etc.,-ancient loyalties have their monuments.

There are many homestead names that pique antiquarian curiosity. Did "Brompton" remember the London residence of the Rev. James Marye, or "Wakefield" transmit some association of the Washingtons with the Yorkshire town? Does Sabine Hall owe its name to the classical Landon Carter's interest in the squaws carried off by the Moraughticunds, like the Sabine women of antiquity? There are, however, still a good many names which do not leave us to conjecture. Mannsfield was the seat of Mann Page, Edmundsbury of Edmund Pendleton, and Tazewell Hall of the Tazewells. "Crow's Nest" was given to Travers Daniel's place on the Potomack because he had a swift vessel called "The Crow." The farm on the Accokeek where Captain Augustine Washington had his iron-works is still called "The Furnace," and that part of it which yielded its forest for the furnace is called "The Woodcutting." Among the footprints of the Revolution is a 
184 BARONS OF THE POTOMACK

farm called "The Forge," just above Falmouth (Stafford side), where one may pick up bits of iron left from the time when cannon were made there under superintendence of Colonel Fielding Lewis and Major Charles Dick. "The gentlemen of this town," wrote Major Dick to the governor (Fredericksburg, January 4, 1781), "and even the Ladys have very spiritedly attended at the Gunnery and assisted to make up already 20,000 cartridges with bullets from which the Spottsylvania Militia, and also from Caroline, have been supplied, as also above 100 guns from the Factory." This "factory" is now "The Forge," and the place where the guns were delivered in Fredericksburg is still called "The Gunnery." About the same time, we may feel sure, the house of General Weedon in Fredericksburg received the name it still bears - "The Sentry Box."

Our Folklore Society would be repaid by a month's ramble in Tidewater Virginia. A great many strange events went to make the peculiar character of that region, and some of them occurred in such remote places that, in the absence of newspapers, they may be described as prehistoric. But here and there they are recorded in local names and tradi- 
tions. These traditions are, indeed, sometimes slovenly, as where "Mock Jack" is turned into "Mob Jack Bay." "Blackbeard's Point," near Hampton, was so named, it is said, because the pirate's head was displayed there in terrorem. The death of Teach excited attention in all of the colonies; and it was probably the ballad on that event written by the young printer, Benjamin Franklin, which brought him the friendship and patronage of Governor Spotswood. Probably the pirate's head was exposed at that point, and possibly neighboring "Wolf's Trap" was associated with Teach. For it is noticeable that the names of this kind that last longest are those derived from some tragical or terrible event. It is now the fashion to write of Nathaniel Bacon as a patriotic revolutionist, but the spot which has not been washed from his hand is visible in the name "Bloody Run," near Richmond, which ran with more Indian blood than it had water.

To hang up Blackbeard's head would be in accordance with the custom of the times. The Rev. Frank Stringfellow, an Episcopalian clergyman of Virginia, tells me of a remarkable series of names recording the similar fate of some negro offender. In traveling from the 
Appomattox, Chesterfield County, one passes "Skinquarter Creek," where the criminal was hung and flayed, his skin being displayed. Journeying on the high-road, one finds in Powhatan County "Negro Arm Road"; in Hanover County is reached "Negro Foot P. O." ; and finally, in Orange County, "Negro Head Run."

The long and furious struggle between the Indians and the white settlers for the valley of Virginia is recorded in many names and traditions. A great battle was fought on the Wappatomaka (great south branch of the Potomack), whose only record is the "Painted Rock." Kercheval, writing in 1833 , says: "On this rock is exhibited the shape of a man with a huge blotch, intended, probably, to represent a man bleeding to death. The stain, it appeared to the author, was made with human blood. The top of the rock projects over the painted part, so as to protect it from the washings of the rains, and is on the east side of the rock. How long the stain of human blood would remain visible in a position like this, the author cannot pretend to express an opinion; but he well recollects the late Gen. Isaac Zane informed him that the Indians beat out the brains of an infant (near 
his old iron-works) against a rock, and the stain of the blood was plainly to be seen about forty years afterwards. In this battle, it is said, but one Delaware escaped, and he did so by leaping into the river, diving under the water, and continuing to swim until he crossed the Cohongoruton [Potomack]." I have seen in India red stains on a rock said to be the blood of St. Thomas, shed there eighteen centuries ago; and here is a superstition of the same kind in Virginia. Human blood does not last so long, but "bad blood" does; and it is to be feared that the Painted Rock, in the absence of geological knowledge, long called down vengeance upon the poor red men.

A pleasanter set of legends are found along the Rappahannock, and particularly about the old town of Falmouth, which "before the war" was distinguished for its wealth and aristocratic homes. Most of the great families of the Northern Neck had representatives there. It organized an association against the Stamp Act, and in the Revolution was an important resource. From Falmouth provisions were sent to beleaguered Boston. Its cottonfactories, flour-mills, warehouses, are now ruins; its once elegant homes are mainly occupied by negroes. Some historic notes con- 
cerning this old town may be interesting. Its hills are natural fortifications, and were used as such by the Indians, who there fought Captain John Smith in 1608 . In 1675 it was fortified, and Major Lawrence Smith there established a little principality. With two commissioners from the non-military inhabitants, and six chosen by a majority of the two hundred and fifty soldiers assigned to the fort, Major Smith held a court as if Falmouth were a county. The soldiers were free from taxes, and from arrest or suit by any outside power save Majesty. The garrison regulations were severe, and it is remarkable how many of them were pious. A blasphemer, "drunk or sober," or one who derided the Bible or the sacraments, must run the gauntlet of one hundred men, and, if wilfully persistent, be bored through the tongue with a hot iron. After a third conviction for swearing, the offender must "ride the wooden horse with a musket tyed to each foot, and ask forgiveness at the next meeting for prayer or preaching." This was also the punishment for drunkenness, and for laziness in any military service. Attendance at daily prayer-meeting or preaching, morning and evening, was compulsory. The hand lifted against an officer, "whether 
he hitt or misse," was cut off; the talker while on march was "laid neck and heels" for an hour; and nine offences were punishable with death. Major Smith's military princedom, apparently contrived to protect the Deity rather than the frontier settlers, lasted only a year or two, but its effects were felt long after. Falmouth became noted for prayer and profanity, for drunkenness also, and a passion for military parades. The old English Church -the "Cedar Church" - was abandoned, its materials being used for a grain-warehouse on the river-side, where it was swept away by a freshet. In its place was built a communal church, which still stands, where all sects worshipped. The drunkenness and profanity of Falmouth prevailed among its large number of "poor whites" and mulattos, descendants probably of Major Smith's two hundred and fifty. Such vices were so vulgarized that the gentry were comparatively free from them; and the same may be said of Fredericksburg and other places. I always listen with skepticism to anecdotes representing George Washington as occasionally indulging in profanity, as well as to those that ascribe to him great piety. In his early life profanity was regarded as a symptom of familiarity with poor whites 
and negroes; it was ungentlemanly among Virginians, though the habit was sometimes caught from English officers.

Falmouth was long a nest of old legends, which haunt both sides of the river. On the Spottsylvania side Francis Thornton had dwelt before the foundation of Fredericksburg, almost a hermit in his loneliness. His "Punch Bowl" is shown, hollowed in the top of a rock; and a hundred years after his time a huge living tortoise was said to have been found bearing on its shell the carved initials "F. T." Above the town, on the Stafford side, is an island where it is said Governor Spotswood proposed to realize a Utopia; until lately the dream was represented in a solitary ruin. Two brothers of the poet Campbell were merchants in Falmouth, and tradition said that " Lord Ullin's Daughter" was written beside the falls of the Rappahannock. But Thomas Campbell never visited Virginia, though he longed to do so, except in imagination. His brother Robert (Mr. Wirt Henry says William) married a daughter of Patrick Henry.

Besides the Campbells, there was a large number of Scotch families who settled in Virginia as tobacco-traders, but were ultimately the means of doing away with the culture of 
that staple both on the Potomac and the Rappahannock. They discovered that more wealth could be made by exporting grain. In Falmouth there is a small house of two rooms, called "Gordon's Corner," associated with a "survival" of the canny settlers. Basil Gordon came to the village a penniless lad, and bequeathed more than a million to his family. He was not miserly, but after he had gained wealth, and resided in a fine house, still kept up the tiny "store" in which he earned his first pennies. It was a joke of some of his fashionable neighbors to enter the store, call for Mr. Gordon, and ask for a half-pound of brown sugar, which the millionaire would scrupulously weigh out. This went on to the day of his death.

Although the inhabitants of Falmouth were chiefly of Scotch extraction, there were some English, Irish, Dutch, and French. There was a good deal of superstition among poor whites and negroes. The great Hindu myth of Ahi, the drought-dragon slain by Indra that the waters might be unloosed, migrated to that region, where it was well understood by the credulous that a snake hung up would bring rain. It was also said that however much a snake might be bruised, "its tail will not die 
till sunset"; a variant being that the tail would live until it thundered. Among the negroes, stories were told of vast conflagrations seen by some traveler only half a mile away, to which he would hasten only to find a small coal of fire. There were various legends of mothers coming out of the graveyard to walk with their sons, when these were returning from some midnight revelry, and admonish them. Some distinguished "conversions" were attributed to these maternal revenantes. The haunted house was apt to be the supposed scene of nocturnal orgies, with loud laughter and quaffing of bumpers. Unusual diseases were sometimes attributed to witchcraft. The present writer remembers, less than fifty years ago, the last of the "witches" -a poor woman (white) at Falmouth, who was so shunned as a witch that she resolved to subject herself to the ordeal of water. She drowned herself in the Rappahannock, and was afterwards remembered as a good-hearted creature who had performed many acts of kindness to those around her. Ortolans were supposed to spring out of frogs at a certain time, and all at once to turn into frogs again. Iron rings were worn for fits - a sequel in Protestant regions to the saintly image worn 
by peasants in Catholic countries for such disorders. In Protestant England a silver coin bearing the royal image was used, and possibly that was sometime the usage in Virginia. Such superstitions were generally confined to the poor and ignorant; but an iron ring was used at Mount Vernon on Patsy Custis, being mentioned in Washington's journal without comment. Warts, it was believed, could be cured by making them bleed, and then applying one or another herb which the herbalist might prescribe, such herb to be afterwards buried.

I avail myself of the miscellaneous character of this chapter to append two curious old letters. One is from the famous Colonel William Byrd, of Westover, to Landon Carter, of Sabine Hall, which has, I suspect, some hidden meaning - perhaps of a satirical kind.

"Sir

"The letter you was so good as to send me this morning I read with some surprise, believing that the Feaver which was lately so strong upon you was not quite gone off. Nor was I altogether mistaken, it seems, because I perceive the Distemper continues, only you apply to a new Physician. Now 
Sir I think it a great Pity, that an honest Gentleman of so much worth and honour shoud be sufferd to languish under this Disorder any longer, and therefore 1 shall agree to contribute all 1 can to his Recovery. I can foresee no more than one Obstruction to a complete cure, which is that he hath Three or Four Wens growing to his side, which are like to draw all the Nourishment from the other Parts. However between this and Sunday perhaps some method can be thought of, to encounter that formidable symptome.

$$
\text { "I am Sr }
$$

"The most obedient of your servants,

"July the 26th, I742." "W. BYRD.

The next letter is from Robert Carter, of Nomony,-Councilor Carter,-who has the distinction of being the earliest Swedenborgian in America, and who liberated his slaves during his life because of religious principles. It is addressed to Dr. George Steptoe.

$$
\text { "Nomony Hall I2th July i77ı. }
$$

"Sir,

"Your letter, which you Call an Answer to one I wrote to you last Tuesday, Doctr Francks 
delivered to me-the Doctr waited on you, not to precipitate an answer but to know whether you had received the letter mentioned above, because letters frequently miscarry. You say it is remote from your Intention to violate the laws of any Country wherein you Dwell; that your present Endeavours are to prevent the fatal Effects of one of the most Malignant diseases; that it is not your Intention to Introduce general Inoculation, and that you have taken all precautions to prevent the propagation of the Small-pox in this Instance. Does the Act of the Legislature referred to in my former letter tollerate, without Licence, either a partial or General Inoculation? If it does not your present Endeavours, tho' the Inoculation be partial, be in direct opposition to that Written law of the land. It is said that Master George Turberville infected his Brother and four Negro's who were his most Common playmates; that those were the Only persons who caught the Small-pox of Master George; that you procured Matter of Doctor Jonathan, and with it have Inoculated about seven Whites, and a much greater Number of Blacks. If this report be not fabulous it will be insisted that if that malignant disease had not been propagated 
196 BARONS OF THE POTOMACK

by Inoculation att Hiccory Hill, and due attention given to those there who caught it the Natural way, that the Suppression thereof would have been less Hazardous, than as the case now stands - therefore your Conduct strengthens the probability of its generallityI say your Conduct but I mean the Conduct of those gentlemen, who procured the Inoculation of the Small-pox - for I consider you as the secondary Only. The present scheme of Inoculation is not defensible, and I again Intreat you to desist therefrom. Whatever your apprehensions of me now are or may be hereafter, $1 \mathrm{beg}$ to tell you that my sincere Intention is to patronize you, believing you possess Quallifications to make your Company Destinct in this or any other Community.

"I am Sir your most Obedt Servt

"RoberT CARTER." 


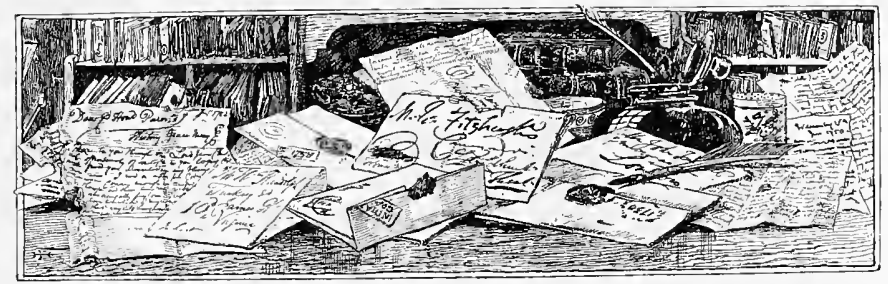

IX

The Fitzhughs

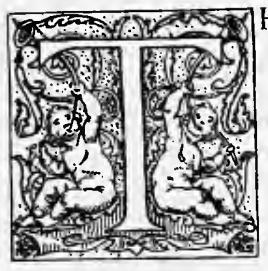

HE hereditary dignities of the Fitzhughs in England ended in the time of Henry VIIl., whose sixth and last wife, Catharine Parr,-reformer and authoress, - was granddaughter of the last Lord Fitzhugh. They traced back to Hugh, Lord of Ravensworth, supposed to be of Danish extraction because of his castle's name and his crest, the raven, still used by the family in Virginia. Two Fitzhughs signed the Magna Charta, and one is on the Roll of Battle Abbey. In the Wars of the Roses they took an active part with Lancaster. Lord 
Henry Fitzhugh married a sister of Warwick, after whose death he was a leader in the rebellion against Edward VI. The last of the male line was one of the Catholic bishops of London. The family was dispersed. One of them became a representative of the East India Company in China, and entertained Captain Cook at Canton. There are descendants of the ancient Fitzhughs in England, but the historic career of the family was resumed in America, to which William Fitzhugh emigrated in 1670 . At Bruton Church, Williamsburg, on the tomb of this first settler's granddaughter, Sarah, wife of King's Attorney Barradell, are the arms of the Fitzhughs: [az.] three chevrons braced in base of escutcheon [or] a chief of the last. But William, a second son (his elder brother, Henry, was a courtier of Charles II.), gained little assistance from his escutcheon in the New World, where, however, he never forgot his motto,-Pro patria semper. He came to Virginia in his twentieth year; secured a grant of land in Stafford ; married Miss Tucker, of Westmoreland, who was (actually) not quite eleven; built him a house which he named after the town of his birth, Bedford; there died at the age of fifty (1701); divided among his five 
sons 54,054 acres in Stafford, King George, and Essex counties; in these sons founded a race that has spread through America-for it is believed that all the Fitzhughs in this country are descended from the immigrant William and the eleven-year-old wife he married in his minority. He was lawyer, planter, shipper, statesman. There is interesting information concerning him in Miss Rowland's excellent biography of George Mason. In the time when Virginia was in panic at a rumor that the Maryland Catholics meant to bring over Indians to destroy the Protestants (1688-9), Captain Brent, a Catholic, took refuge in the house of his Protestant neighbor, William Fitzhugh, who bravely defended him from the mob, and protected him five months, meanwhile expecting to be himself murdered. He consumed three quires of paper in writing and sending out messages to quiet the panic, which was mainly excited by a fanatical nonconformist preacher named Waugh. Possibly the gallant William Fitzhugh had in his youth witnessed the persecutions of John Bunyan in his native Bedford.

The five sons of this first William Fitzhugh married in America and had families. One of them, Henry, married a Miss Cooke, of Glou- 
cester Comnty, damphter, it is suid, of one of the hundrad English virls imported soon atter Balcon's robellion. This was his second son; the eldest, William |zd|, married Ann Lec, dimghter of Commcilor Richard lec, and resided at " Ealgle's Nest, "King George Comty. These had one son. Henry, who married Luy, danghter of "King Carter." The last mamed also had only one som, the eminent publicist. William Fitahugh [ 3] of Chatham. It is enenerally stated that William of Chatham Was grandson of the tirst settler, but 1 am following Georse Fitzhugh, of Port Royal, for some of whose papers I mm indebted to his damghter. Mrs. Champe Fitzhugh Thomton.

It was the custom of Virginia gentlemen in colonial times to build or purchase houses for their soms, and two of the fitzhugh mansions in Stattord, ne:ur Fredericksburs, were so built - Boscobel and Belair. But Willam Fitzhugh | , l| has always been credited with building (1750) his picturesque Chatham, - which is now recovering its name, having been known as " Latey's" while headquaters of the Amy of the Potomake. Colonel Willian Fitzhmgh, of Chatham, married a Randolph: a daughter of these, Mary Lee Fitzhugh, married Mrs. Cieorge Washington's grandson, G. W. P. 
Custis, of Arlington, whose danghter married Gencral Robert E. Lae. Major lacy, owner of Chatham while it was headyuarters of the Union ammy, has stated that he one day (before the battle of Fredericksburg) approadsed lee and pointed to the oflicers walking about the gromeds of Chatham. He advised the general to shell the place, but lece hate not the heart to destroy a mansion will which he hatd such fender associations. Sone officers may owe flreir lives to this sentiment of the Confederate chief, and to it a Norfluern gentleman owes his possession of the historic mansion.

Chatham was a station for all distimguished travelers between the lower and upper commtries; it was never without gruests; and when the Fredericksburg fairs and races occurred the terraces were covered with coaches. As his years advanced Colonel William Fitzhugh had to escape from all this, and passed the rest of his life at Ravensworth, in farlax. He was always a devoted friend of Washington, and must have known him as a boy, for the Washington larm adjoins Chatham. The following was written to the son of Colonel William Fitzhugh by President Washington, June 16, 1793: 
"The China Bowl with which your good Father was kind enough to present me came safe, and I beg you to assure him that I shall esteem it more as a memento of his friendship than from its antiquity or size. Not before the receipt of your letter, dated the 24 th of last month, had I heard of the death of Mrs. Fitzhugh. On this melancholy event I pray you both to accept my sincere condolence. I also sincerely wish that the evening of his life although at present clouded, deprived of one of its greatest enjoyments, may be perfectly serene and happy:- that you will contribute all in your power to make it so I have no doubt."

William Henry Fitzhugh, to whom the above note was written, married a Goldsborough of Maryland, and died childless. He was an only son, and that branch of the family ended with the death of Mrs. [General] Robert E. Lee's mother. But the old tree had a banyan growth in the Northern Neck, planting stems at Eagle's Nest, Marmion, Boscobel, Belair, Selwood, Chatham, Ravensworth, and several other places. Bishop Meade was one fruit of it. The fine intelligence and scholarly traditions of the family found a remarkable 
representative in the late George Fitzhugh of Port Royal, well remembered by the present writer as a profound thinker and vigorous writer. He fell upon an era of reaction from the old anti-slavery principles, and wrote a philosophical defence of Southern "Sociology." In one of his valuable historical papers in De Bow's "Review" he speaks of two members of the Fitzhugh family: "These two sisters of the name, strange to say, intermarried with two distinguished abolitionists (and married well), Hon. Gerrit Smith and Mr. Birney. This branch of the family is descended from the Masons of Gunston, and inherit much of their military and adventurous spirit."

Not so "strange to say," after all ; for William Fitzhugh of Chatham manumitted by will his two hundred slaves, and the injustice of slavery was a conviction of every Virginia gentleman until, some two generations ago, President Dew of William and Mary College announced the new "Sociology," which captivated the younger generation. A few years before the war, George Fitzhugh of Port Royal was invited, as the ablest defender of the new "Sociology," to expound his views in a Northern city. He was hospitably entertained at New Haven and Hartford, listened 
to without dispute, and driven about those places to witness some results of what had been called "the failure of free society." The present writer had a letter from him shortly after, expressing his enjoyment of this visit, and, though he did not so say, l feel certain that his old opinions were somewhat shaken.

George, fourth son of the first settler, William Fitzhugh, married Mary Mason of "Gunston," Maryland, the name of which residence was repeated in "Gunston Hall," Virginia, home of George Mason the statesman. Their son was the famous Colonel William Fitzhugh, of the Cartagena expedition, two of whose letters are in the Havemeyer collection. "Colonel William Fitzhugh," writes Miss Rowland, "son of George and Mary Mason Fitzhugh, married first Mrs. Martha Turberville, née Lee, a daughter of Richard Lee and niece of Thomas Lee of 'Stratford.' By this marriage he had one son, George Lee Mason Fitzhugh. Colonel Fitzhugh married secondly Mrs. Ann Rousby, née Frisby, of 'Rousby Hall,' Calvert County, Maryland, and the children of this marriage were Peregrine, William, and John Fitzhugh. Peregrine and William were both officers in the Revo- 
lutionary War, and the former served on General Washington's personal staff." George Fitzhugh of Port Royal says this Colonel William Fitzhugh surrendered his commission in the British army, rather than fight against America, and, he believes, "was detained as a prisoner during the war." Miss Rowland does not mention this, but states that he resigned his commission in June, 1776, and served on the Committee of Vigilance of Calvert County. "But during his absence from home [as a prisoner?] in 1780 and in 1781 , the enemy landed there ['Rousby Hall'] and burned the buildings and furniture, and carried off forty-two of his slaves."

The two letters subjoined convey a good impression of Colonel Fitzhugh in earlier life, and of the loyal spirit of those who were presently found struggling against the mother country for which they had fought with enthusiasm. Although Colonel William Fitzhugh afterwards resided in Maryland, having married the widow Rousby of "Rousby Hall," he previously resided in Westmoreland, and his commission as ensign in the Cartagena expedition was received from the Council of Virginia. Both letters are addressed to Major Lawrence Washington. 
"Westmoreland, May ye 15 th, 1747.

"Dear Sir,

"Collo Lee informs me that you were so kind as to bring some Papers for me to Williamsburg, which I'm sorry I happened not to be there to receive, and which $I$ shall be obliged to you for sending me by the first good opportunity. The Governour [Gooch] has promised to use His Interest in my favour, and I'm a little unfortunate in that I have not the least acquaintance with The Lord Fairfax, whose Letter wou'd do me singular service in the affair. I'm doubtfull of success, as I believe it will chiefly depend on my personal appearance in England, which I can't possibly comply with at present. As for the half pay, I shou'd be very hapy if there was any other way to establish my Rank in the Army, which is all I want.

"Yesterday I received a letter from one Gilbert, a friend of mine who now commands Plimouth Garrison, dated ye 28th of December 1746, part of which runs thus: 'Most of the American oficers have been here. I suppose you have heard that poor Capt. Bishop was miserably butchered by the Rebbels at the Battle of Falkirk. Addison now commands six additional Companys in this Town.' The 
account of the destruction of our unfortunate friend puts me in mind of what you mentioned to me concerning two of his sons in Philadelphia, relating to whom he wrote you. I shall be glad to take one of them, and do him any service in my power, as a mark of that friendship $w^{\text {th }}$ which I allways esteem'd his deceas'd Father. So if you incline to take the other you may please to give Directions for their coming hither, in which expence, if any arises, I will readily contribute with you to discharge.

"I did intend you a visit about the time of your return from the Assembly, but the death of my son prevented my taking that Pleasure. I was in hopes, on hearing of a Diference between our friend Collo Colvil and Conway, that a Battle wou'd have ensu'd, but the Gazett informs me the former has cut the latter down with his own Weapons. Mrs. Fitzhugh offers her Complts to you and your Lady, to whom please to present those of $\mathrm{Yr}$ Afft and Oblig'd Humble Servt

"Willm Fitzhugh."

It is Plymouth, England, that is alluded to. When the Revolution broke out Colonel Fitzhugh was drawing half pay as "captain" in 
what was still called the Gooch Regiment. Colonel Colville was a neighbor of Major Lawrence Washington in Fairfax, and there was a Conway family there also, one of whom was an early Mayor of Alexandria; but the controversy of these men, since it was noticed by the "Virginia Gazette" (founded at Williamsburg in 1736), would appear to have been of general importance. The next letter of Colonel William Fitzhugh is as follows:

\section{"Dear Sir,}

"As you were so kind to promise me the Certificates and other Credentials sent over to you in Order to receive your Half Pay, I now send a Messenger for them. I'm at Mr. Graham's and did intend to have waited on you but I have been very 111 and am now so weak that I find myself Incapable of Performing the Journey. I have received letters from England that advise ye Establishment of my Half Pay, and have received part of it. The rest waits for proper Certificates. I have also Advice of Capt. Hall's being One of the Unhappy Persons that was Butchered at Falkirk. Capt. Stafford has been sometime in Newgate on Suspicion of Treason, but is at last discharged 
both from Confinement and his Majesty's Service. There is a Report below, of a Grand Battle Fought between his Royal Highness the Duke and ye French Army, in which the latter have lost all their Artilery and 30.000 Men, and were Intirely routed. This report 'tis said is Confirmed by Several Private Letters to York and Other Places. If this be true I hope the Monseurs will be Convinc'd that One English Duke has more Interest in Heaven and Power on Earth than all the Saints they Worship or Pray to for Success.

"I Heartily Congratulate you and your Lady on the Birth of your Son, and as I know yre a man desirous of Increasing the World I wish you many more.

"If you should not be at home when this Comes to Hand, as the Messenger can't Wait, I shall take it as a Particular favour that you'l Hire a Person to bring down those papers. I will thankfully pay him whatever you agree for.

"Please to make my Compliments acceptable to your Lady.

"l am your affecte Humle Servt, "Willm FitZHugh.

"Quantico, September 9th, 1747." 
The "Mr. Graham" at whose house this was written was probably either John or Richard, leading men in Dumfries, Virginia, then a flourishing place, now represented by ruined chimneys and a few cabins.

The son on whose birth Major Lawrence Washington is congratulated was Fairfax Washington, born August 22, 1747, died in October of the same year.

In 1754 Governor Sharpe of Maryland, having received the King's commission as commander of forces against the French, appointed Col. Fitzhugh to command of the army. Col. Fitzhugh at once made an effort to persuade Col. George Washington back into the service from which he had retired with dissatisfaction. (Sparks, ii, p. 64.) In this he was unsuccessful. Toward the close of his life, Col. Fitzhugh established at Millmount, a farm contiguous to Rousby Hall, a manufactory of ship-bread for vessels trading in the Chesapeake.

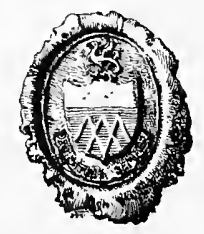




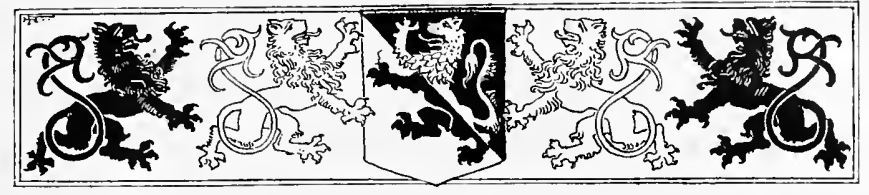

$\mathrm{X}$

A Lord and a Lad at Belvoir

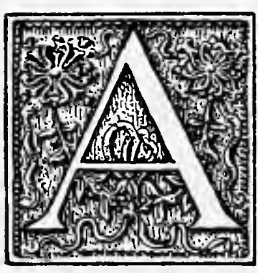

MONG some old Carter manuscripts my eye was caught by one bearing the now historic name of "Bull Run." It is a deed, dated October 12, I724, opening with the following words: "The Right Honble Thomas Lord Fairfax of Leeds Castle in the County of Kent and Baron Cameron in Scotland and William Cage of Millsgate in the Parish of Bearstead in the said County of Kent Esqr Devisee in Trust and Sole Execur of the last will and testament of the Right Honble Catharine Lady Fairfax de- 
ceased ppr of the Northern Neck of Virginia, To ALL TO WHOM this present writing shall come send Greeting: KNOW YE That for divers good causes and considerations but more especialy for and in consideration of the composition for our use paid unto our Agent and attorney and for the annual rent hereafter reserved WE HAVE given granted and confirmed and by these presents for us our heirs and assigns do give grant and confirm unto Robert Carter Gentn Son of Robert Carter Esqr of Lancr County one Certain Tract or parcel of land scituate lying and being in Stafford County Containing six thousand and thirty acres on a branch of Occaquan called Bull Run, etc." For this, Robert Carter, Jr., is to pay his Lordship's "composition," ten shillings for each fifty acres, and thereafter one shilling annually on each fifty.

Out of his six million acres obtained by the marriage of his mother with Lord Culpeper, Lord Fairfax might well have bestowed six thousand acres gratis, or on easier rent, to identify the interests of the Carter family with his own. But the above were his usual terms. His official connection with the Carters ended in 1732, when "King Carter" died, and Lord Fairfax sent from England an agent named 
Benjamin Borden. On arriving in Virginia, Borden recognized an opportunity of becoming a sort of Lord Fairfax himself. Governor Gooch was then dispensing the Valley lands so freely and indiscriminately that one Jacob Stover, it is said, secured many acres by giving his cattle human names, as settlers; and a young woman, by dressing in various disguises of masculine attire, obtained several large farms. Borden hastened to that region, captured a buffalo calf, carried it to Williamsburg as a present to the governor, and so won the favor of good Mr. Gooch that he acquired a vast tract. Lord Fairfax, finding his interests in Virginia neglected, applied to his cousin, William Fairfax, who settled in Virginia as his agent in 1734 .

The Hon. Col. William Fairfax was a first cousin of Lord Fairfax, his father being Henry, younger brother of his Lordship's father. Henry Fairfax married Anne Harrison, of South Cave, Yorkshire, whose sister Eleanor married Henry Washington. Whether his uncle Henry was related in any way to the Washingtons of Virginia is not known, but William Fairfax may have known more of the matter than is now discoverable. At any rate, he fixed his abode, as we have seen, near that of the Wash- 
ingtons, and the intimacy of the two families was that of relationship. William Fairfax had long been in Government service. He had been a soldier in Queen Anne's wars, Chief Justice in the Bahamas, Governor of the Isle of Providence, and Collector of the Port of Salem, Massachusetts. His first wife was Sarah Walker; by her he had four children - George William, Thomas, Anne (married Lawrence Washington), Sarah (married Major John Carlyle of Alexandria). His wife died in 1731 , expressing on her death-bed the hope that her husband might marry her friend Deborah Clarke. The hope was fulfilled. By this second wife William Fairfax had three childrenBryan (who became eighth Lord); William Henry, a soldier, who fell at Quebec, 1759; Hannah (married Warner Washington, first cousin of the general).

William Fairfax thus brought to Virginia a large family, and at the head of it was a woman whom tradition declares to have possessed extraordinary intelligence and character. Deborah Clarke was daughter of the Hon. Col. Bartholomew Gedney, of Salem, Massachusetts. She married Francis Clarke, October 16,1701 , and became a widow in 1727. The portrait which, by favor of the Essex Institute, 


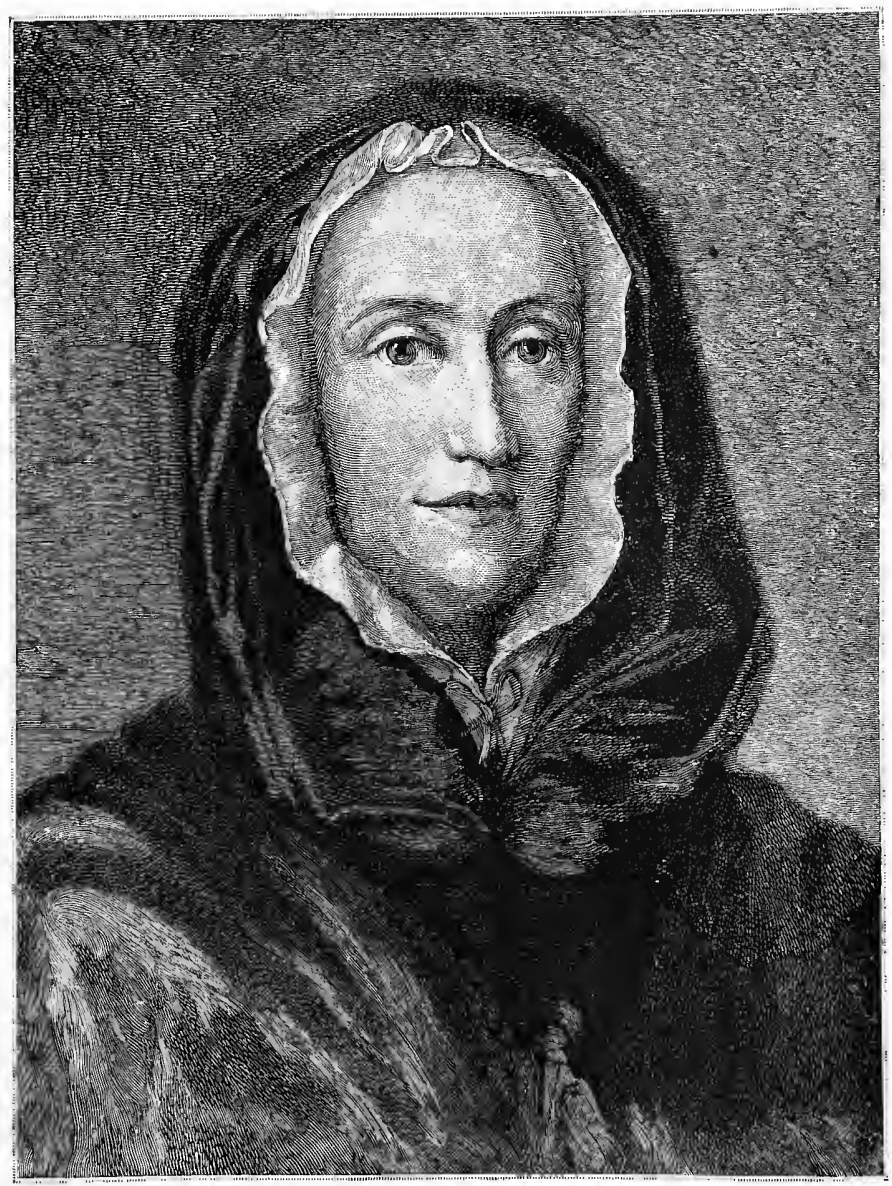

DEBORAH CLARKE. 


$$
\text { • }
$$


Salem, is presented in this volume, was undoubtedly painted by John Smibert of Edinburgh. it represents her in widow's dress, and was probably painted soon after Smibert's arrival (1728) in Boston. The countenance is at once powerful and refined; it can hardly fail to impress one with a feeling that the influence of Deborah Fairfax may have been of importance in forming the character of George Washington, so much of whose boyhood was passed under her roof. She died, as shown by one of our letters, in 1747 .

Lord Fairfax (according to Sir Bernard Burke), "visiting his American estates about the year 1739, was so captivated with the soil, climate, and beauties of Virginia that he resolved to spend the remainder of his life there; and he soon after erected two mansions, Belvoir and Greenway, where he continued ever afterwards to reside in a state of baronial hospitality." But according to tradition, probably correct, Belvoir was built by William Fairfax between 1734 and 1736 . It was destroyed by an accidental fire during the Revolution, and unfortunately no picture of it can be found. Its architectural character may be gathered from an advertisement in the Gazette of Philadelphia, October 19, 1774: 
"To be rented from year to year, or for a term of years, Belvorr, the beautiful seat of the Honorable George W. Fairfax, Esq., upon the Potomac river, in Fairfax County, about 14 miles below Alexandria. The mansion is of brick, two storeys high, with four convenient rooms and a large passage on the lower floor; five rooms and a large passage on the second; servants' hall and cellar below. Convenient to it are offices, stables, and coachhouse; adjacent is a large and well-furnished garden stored with a great variety of fruits, all in good order. Appertaining to the tract on which these houses stand and which contains near 2000 acres (surrounded in a manner by navigable water) are several valuable fisheries and a good deal of clear land in different parts which may be let all together or separately as shall be found most convenient.

"The terms may be known of Colonel Washington who lives near the premises, or of me in Berkeley County.-Francis Willis, Junior."

I have from a descendant of the Fairfax family, now residing in Virginia, a copy of the list of articles sold at the auction held at Bel- 
voir August 15, 1774, and the prices brought. This I conclude to copy literally.

\section{DINING ROOM.}

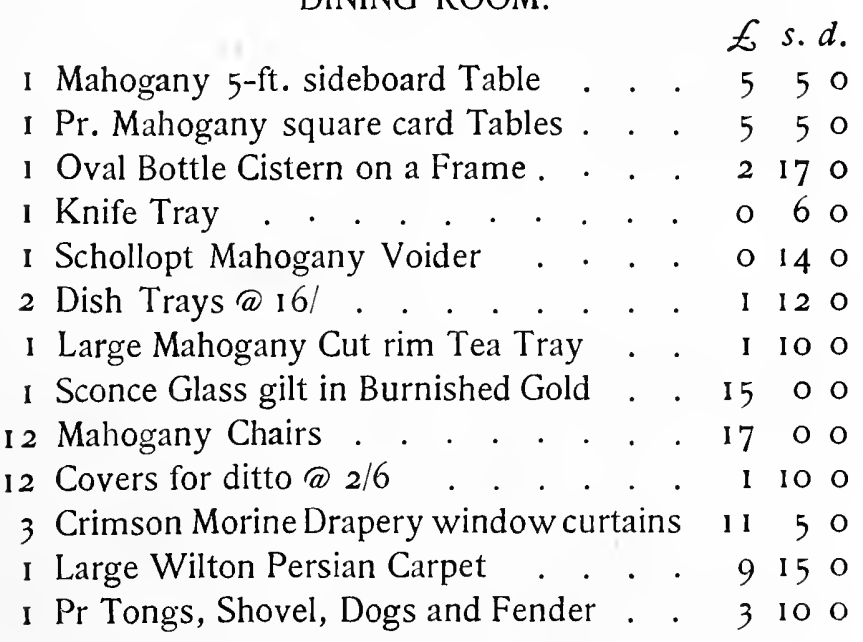

\section{PARLOR.}

I Mahogany Table (dining) one glass to take off . . . . . . . . . 3150

I Mahogany Spider leg Table . . . . . 250

I folding fire skreen lined with yellow . . 1 I 0

2 Mahogany Arm Chairs cov'd with figured hair . . . . . . . . . 550

1 Chimney Glass . . . . . . . . . 1000 Dogs, Tongs, Shovel and Fender . . . 2146

2 Saxon green plain Drapery curtains . . 500 
MRS. FAIRFAX'S CHAMBER.

I Mahogany Chest of Drawers . . . 8100

1 Bedstead and Curtains . . . . . . 8 o 0 Window Curtains . . . . . . . 1150

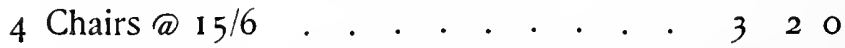
Covers for Do@2/. . . . . . . 0 o 80 Dressing Table . . . . . . . . . 10 o 0

I pr. Dogs, Shovel and Tongs . . . . 1130

COL. FAIRFAX'S D-G ROOM.

I Oval Glass in Burnished Gold . . . 510 o

1 Mahogany Shaving Table . . . . 330

1 Mahogany Desk, \&c. . . . . . . 16160

4 Chairs and Covers@22/ . . . . . 480

1 Mahogany Settee Bedstead Saxon green . 718 o Covers for Ditto . . . . . . . . . 090

I Mahogany Pembroke Table . . . . . 1 I 8 o Dogs, Shovel, Tongs and Fender . . . 1130

\section{UTENSILS \&C.}

I Case and I dozen bottles . . . . . . 1160

I pr Garden Shears, I snuffer stand, bales, Brushes . . . . . . . . . . 013

2 Flint Decanters 2/an old pine desk . . o 186 A large pot, a lanthorn 6/ lot of Queen's china

9 Knives and 1o Forks 10/, I pr Endirons 5/

I 160

I pr Scales \& 5 weights I0/, 2 pr. Stilyards

0170

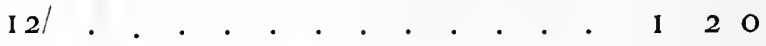


2 Brass Candlesticks 9/, 2 Copper Stew-

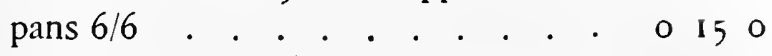

I Copper Fish kettle 18/, 4 do stewpans and covers . . . . . . . . . . . I I 4 O

3 Saucepans 5/, 4 do kettles $10 /$. . . O I 50

I Tea kettle, 2 Cannisters and oven 15/, Pestel \& mortar $12 / 6$. . . . . . . . 176 23 [?] and 9 qt Bottles . . . . . . . 076 2 Old Flour Searchers . . . . . . . 076 I hand mill 30/, 180 gal. Copper kettle . 350 I large iron pot 20/, 1 Bread Toaster $1 / 3$. I I 3

The books have no prices attached. They are: Batavia lllustrated; London Magazine (7 vols.); Parkinson's Herball; Knolles' History of the Turkish Empire; Coke's Institutes of the Laws of England (3 vols.) ; England's Recovery; Laws of the Colony of Massachusetts Bay; Lex Mercatoria, or Laws of Merchants; Laws of Virginia; Compleat Clerk and Conveyancer; Hawkins, Pleas of the Crown ; Gunnall, Offences in the Realm of England; Ainsworth, Latin and English Dictionary; Haine's Dictionary of Arts and Sciences; Blackmore's Prince Arthur; History of the Twelve Cæsars, by Suetonius; John Calvin's Institutions of Religion; Fuller's Church History from its Rise; Locke on the Human Understanding; A New Body of Geographie; 
Croope's Reports; Heylin's Cosmographie in 4 Books; Collection of Voyages and Travels; Political Discourses, by Henry Earl of Monmouth; Wooten's State of Christendom; Hobart's Reports; Johnson's Excellency of Monarchical Government; Latin and French Dictionary ; Langley's Pomona, or Gardening ; Obreneter, a Political Piece; Strada's History of the Low Country Wars; Spanish and English Dictionary; Latin Bible; A Poem on Death, Judgement, Heaven and Hell ; Knox's Martyrologie; Jacob's Law Dictionary ; Chamberlyn's State of G. Britain; Hughes, Natural History of Barbadoes; Laws of His Majesty's Plantations; The Way to get Wealth.

One or two of these, it will be observed, were published in the later colonial period. Probably the books were not sold, for some later hand has added to the list a work of 1777 , with the full title-page and dedication: "A Compendious View of the Civil Law; being the substance of a Course of Lectures read in the University of Dublin, by Arthur Browne, Esquire, S. F. T. C. D., Professor of Civil Law in that University, and Representative in Parliament for the same. 1777. Inscription: To His Excellency Gen. Washington, with the utmost respect, this Book is humbly presented 
by the Author, once an American, who knew in America his earliest and his bappiest days."

The sale brought about $£_{242}$, Washington's purchases, which included no books, amounting to $£ 169$.

Such then was Belvoir and its contents. The Hon. Colonel William Fairfax found his Lordship's affairs in such a condition as to require all of his administrative ability and personal tact. The immense territorial claim of Lord Fairfax, dating from a time (Charles II.) when much of the land had not been discovered, confirmed to Lord Culpeper by the discredited James Il., was disputed on every hand. It was not fully acknowledged by the Crown, which wished to earn rents by new grants; its northern boundary was disputed by the Maryland proprietary, its eastern and southern by many settlers. On the Maryland side the question was which of the two head-streams of the Potomack was intended to be the northern boundary of Lord Culpeper's purchase, or Fairfaxland. In Virginia the dispute was concerning the grants of settlers east of the Alleghanies, and also as to which of the two head-streams of the Rappahannock was the Fairfax limit - the Conway (confluent of the Rapidan) or the Rappahannock, between these 
being all the land now comprised by Culpeper, Madison, and Rappahannock counties. William Fairfax first appears in his Lordship's affairs in 1733-4. On a petition of Lord Fairfax, the King appointed a "Commission for running out and marking the limits of his Patent." The three commissioners for the Crown were Colonel William Byrd of Westover, John Robinson, and John Grymes. Lord Fairfax appointed William Fairfax, William Beverley, and Charles Carter. Colonel Byrd has left a narrative of their survey, which began at Fredericksburg, October 12, 1736, and ended December 14. In pursuance of their report, Lord Fairfax gave warning to Joist Hite and his partners that they must purchase or vacate I 40,000 acres for which they held warrants. A lawsuit began in 1736 , which was settled in favor of the Hites, 1786 , when all of the original parties were dead.

The Hite-Fairfax lawsuit, and the general struggle of the settlers in Fairfaxland with his Lordship, deserve a consideration not yet given to them by historians. Here was a tremendous and continuous training in hatred of aristocracy. The accident of birth had thrown into the hand of one Englishman six millions of acres in a country he never saw, 
and made fiefs of a thousand estates tilled by Virginians, while he was hunting foxes around his castle in England,-that same "Leeds Castle" after which the "Manor of Leeds" was named in Culpeper. Although Lord Culpeper had purchased the proprietary title of the Northern Neck (1683), the right to sell it represented an arbitrary claim of Charles II. to give away Virginia to his personal friends ; and the abdicated James II. was also associated with it. Since 1692 there had been a lawful resistance in Virginia to this establishment in the colony of a despotic realm, whose agent was angrily nicknamed "King Carter." This label was the first cry against royalty. By the great wealth and influence of "King Carter," and by the intermarriages of his family with other powerful families, the Fairfax realm was maintained, but it is doubtful whether it could have continued but for the support of William Fairfax, who was Collector of South Potomack; and equally, perhaps, the alliances of his family with the Washingtons, Carys, and Carlyles. Above all, probably, the marriage of Anne Fairfax with Lawrence Washington, allying the powerful Whiting and Butler families, and the later marriage of Hannah Fairfax with Warner Washington, 
bringing in the Warners and Lewises, added strength to his lordship's principality, while the swarming immigrant democracy of Western Virginia was regarding it as a transfer to Virginia of a dynasty discredited and overthrown in England.

What a strange motley West there was in the colony it would require a volume to portray. I cannot go into that, but by way of episode introduce two little illustrations of the Western Virginia of that time. The first is a petition signed by the leading men of the region, ignored and ignorant. It is dated July 30,1742 .

"To the Honorable, William Gooch Esqr His Majesty's Lieut: Governor \&c. \&c. "Sr

"We your pittionours humbly sheweth that we your Honours Loly and Dutifull Subganckes [subjects] hath ventred our Lives \& all that we have in settling ye back parts of Virginia which was a veri Great Hassirt [hazard] \& Dengrous, for it is the Hathins [heathens] Road to ware [war], which has proved hortfull to severil of ous that were ye first settlers of these back woods \& wee your Hombile pittionors some time a goo pittioned 
your Honnour for to have Commissioned men amungst ous which we your Honnours most Duttifull subjects thought properist men \& men that had Hart \& Curidg to hed us $\mathrm{y}^{\mathrm{n}}$ time of [war] \& to defend your Contray and your poor Sobgacks Intrist from ye voilince of ye Haithen-But yet agine we Humbly persume to poot your Honnour yn mind of our Great want of them in hopes that your Honner will grant a Captins' Commission to John McDowell, with follring ofishers, and your Honnours' Complyence in this will be great settisfiction to your most Duttifull and Humbil pittioners - and we as in Duty bond shall Ever pray."

McDowell was appointed, but killed in the December following. His descendants are leading people in the Valley to this day. Our second glimpse of that region is quoted from the journal of Dr. Thomas Walker, kept during his western exploration in I750, as printed by the late William C. Rives.

"March 16. We kept up the Staunton to William Englishes [in what is now Montgomery County]. He lives on a small Branch, 
and was not much hurt by the Fresh. He has a mill, which is the furthest back except one lately built by the Sect of People who call themselves of the Brotherhood of Euphrates, and are commonly called the Duncards, who are the upper Inhabitants on the New River, which is about 400 yards wide at this place. They live on the west side, and we were obliged to swim our Horses over. The Duncards are an odd set of people, who make it a matter of Religion not to Shave their Beards, ly on Beds, or eat Flesh, though at present, in the last, they transgress, being constrained to it, as they say, by the want of a sufficiency of Grain and Roots, they having not long been seated here. I doubt the plenty and deliciousness of the Venison and Turkeys has contributed not a little to this. The unmarried have no private Property, but live on a common Stock. They dont baptize either Young or Old, they keep their Sabbath on Saturday, and hold that all men shall be happy hereafter, but first must pass through punishment according to their Sins. They are very hospitable."

English lordship meant very little to these tribes of the western valleys and hills. Lord 
Fairfax had been wiser to concede a wide margin between them and his domain. As the Shenandoah and the Potomack, with united force, break through the mountains at Harper's Ferry, so did the Barons of the Potomack and the transmontane Democracy together break through the boundaries of Fairfaxland, and through the foreign power that had established it. When in 1785 the Virginia legislature enacted "that the landholders within the said district of the Northern Neck shall be forever hereafter exonerated and discharged from composition and quitrents, any law, custom or usage, to the contrary notwithstanding," it was the consummation of a ninety-years' vague struggle between democracy and aristocracy. And during the greater part of that time the Washingtons had been in close relations with aristocracy.

Looking back on the pre-revolutionary era, we can now see that the conflicting forces were chiefly represented by two families which had been preëminently involved in the corresponding struggle in England,- the Fairfaxes and the Washingtons. And of these families two figures stand out above all others in the light of history-George Washington and Lord Fairfax. When Lord Fairfax first 
visited Virginia, George Washington was a child of seven years. It may have been among his earliest recollections to have seen the nobleman passing his father's house on his way to Belvoir. This live lord, owner of all the land, must have appeared to the child the greatest man in the world. But in the summer of 1746, when Lord Fairfax again came from England, and this time to make his home in Virginia, George Washington was old enough to be reckoned with. In July Mr. Marye's school in Fredericksburg was dismissed for vacation, and his hard-working pupil, George Washington, sped to enjoy his holiday at Mount Vernon and Belvoir, homes in sight of each other, in both of which he was always welcome. At the time of Lord Fairfax's arrival George was a special subject of discussion in both houses; for his brother Lawrence had just obtained for him a midshipman's commission, and they were all trying to overcome his mother's objection to its acceptance. According to a credible tradition, Lord Fairfax at once took a fancy to the boy. The old bachelor of fifty-seven was literary, philosophical, shrewd, and could hardly fail to be interested in this studious lad of fourteen, who had written out so carefully the old 
French "Rules of Civility and Decent Behaviour," and steadily practised them.

Lord Fairfax was a scholar and essayist, and well acquainted, we may feel sure, with all salient facts in the history of the family whose twenty-first traceable generation was represented by himself, the sixth lord. $\mathrm{He}$ could hardly fail to remember that he was meeting as affectionate connections a family which his own had confronted in war a hundred years before. For that year 1746 was the centenary of the famous siege of Worcester, in which that city had been defended by its governor, Colonel Henry Washington, against the great General Fairfax. We can imagine the old lord sitting on the veranda with George, telling him the story of how Sir Henry held out even after the King was a captive and the royal cause lost. He might even show him the letter which General Fairfax received in reply to his demand for the surrender of Worcester, invested with five thousand troops:

"To General Fairfax. Sir: It is acknowledged by your books, and by report of your own quarter, that the King is in some of your armies. That granted, it may be easy for you 
to procure His Majesty's commands for the disposal of this garrison. Till then I shall make good the trust reposed in me. As for conditions, if I shall be necessitated I shall make the best I can. The worst I know and fear not; if I had, the profession of a soldier had not been begun nor so long continued by your Excellency's humble servant, "Henry Washington."

He may even have selected the day of capitulation (July 19) to tell George that it had to be secured by bringing an order direct from the captive King, and he would not forget the honorable terms accorded by General Fairfax to the fortitude and loyal devotion of Sir Henry Washington.

There was one episode of the English struggle which, had it been included in the centenary story, might have brought the history nearer home to his lordship's young listener. In the year that General Fairfax joined Cromwell, the Rev. Lawrence Washington was evicted for loyalty to his king, his family pauperized, his two sons presently driven to repair their broken fortunes in Virginia. The evicted rector's name had descended to the lad's beloved brother, master of Mount Ver- 
non, husband of a Fairfax, as loyal a soldier of George II. as Sir Henry Washington, nephew of his great-great-grandfather, was of Charles 1 .

So, on Belvoir veranda, may have sat the sixth Lord Fairfax, amid his six million acres, and the boy whose highest ambition was to serve their common king. Little did either dream that in them the relative positions of Sir Henry Washington and Sir Thomas Fairfax at Worcester were to be reversed, and the Crown maintained by his lordship to surrender under the siege of George Washington. Behind an impenetrable veil waited the strange hour when his lordship's estates should be saved from confiscation mainly by the influence of him now sitting at his feet. Yet during all that hundred years, since a Fairfax and a Washington confronted each other at Worcester, the evolutionary forces that precede revolutionary changes had worked on these two families. On the morrow of King Charles's death General Fairfax, recoiling from regicide, entered his retreat, and from it emerged only to bear Charles ll. to his throne. On the other hand, Colonel John Washington, who left the commonwealth for loyal Virginia, was presently in collision with 
the King's governor. Thenceforth the Washingtons and the Fairfaxes were borne on in their several currents of eventuality,-currents that flood and float hereditary sentiments. There is a tradition that when the first gun of the American Revolution was reported at the house of Lord Fairfax, Greenway Court, George Washington was dining there. The two friends parted with emotion, knowing that above their affection a demon of discord must prevail. But had they been then suddenly transferred to some distant island, with no past at their back, the titled representative of prerogative might have proved the radical, and our republican chief the conservative.

But let us return to the old lord and his young acquaintance on the veranda. They had not met by accident. The Fate softly weaving between them the destinies of the western world had begun her work in the Old World, and perhaps at an earlier period than the marriage, fifty years before, of two pretty sisters, Anne and Eleanor Harrison, the former to a Fairfax, the latter to a Washington. Those remote love-affairs in Yorkshire brought Lord Fairfax and George Washington together in Virginia, but thenceforth the interweaving 
proceeded with stronger threads. Fairfax, having no son of his own, was attracted by the boy, who had an enthusiasm for literature, and a literary ability - now represented in writings which in the future will make George Washington's highest reputation. The boy read hungrily every book he could get hold of, and experimented in poetry. He had gone through many experiences, was well acquainted with men and things on the lower parts of his lordship's estate. Kindly inquiries could get from him much that it concerned this newly arrived potentate to know. And if the great Fairfax told the youth old stories of the Washingtons and Fairfaxes in England, his listener could tell him brave ones from the annals of his own unexplored principality in Virginia. Traditions were vivid, printed as if in colors in every boy's mind, of Bacon's rebellion, of the Catholic Colonel Brent's flight from Maryland and refuge with Colonel Mason in Stafford, of Parson Waugh's fulminations against the Papists, of the advent of the $\mathrm{Hu}-$ guenots to James River, of Germans to the Rappahannock, and of all the romantic adventures of Spotswood.

Such might be the vistas opening towards the Past, for the nobleman and the boy seated 
on Belvoir veranda. But what of visions in the future? Lord Fairfax was about to take formal possession of the long-disputed boundaries of his great inheritance; he foresaw cities springing up on it, he contemplated for himself a literary retreat, and associated with it his young friend. As for George Washington, his longings would probably have been satisfied by such conditions as those portrayed in the poem on "True Happiness," printed on a previous page. Often, when filling exalted public positions, are heard his sighs for a quiet life at home.

How little do the makers of history know of the forces surrounding them, or of the future they are founding! The English lord and the Virginia boy, seated on Belvoir veranda, gazing on the Potomack, are now visible as the evening star of an old, and the morning star of a new, horizon.

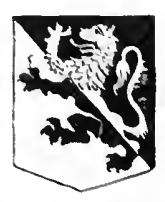




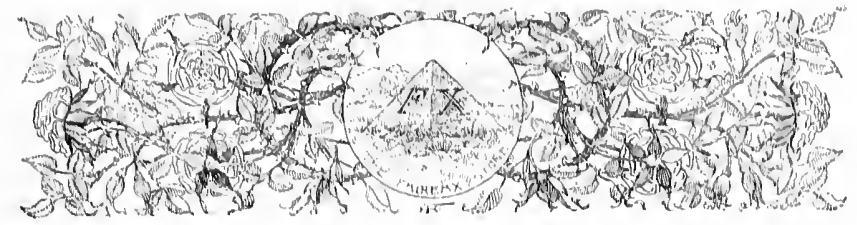

$\mathrm{XI}$

\section{The Fairfax Stone}

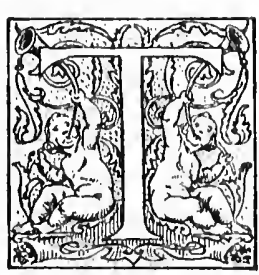

HREE of our original letters relate to the expedition which laid the Fairfax Stone at the head-spring of the Potomack. In 1745 the Crown affirmed the inheritance of Lord Fairfax to be the entire Northern Neck, its western boundary a line from the head-spring of the Conway River (confluent of the Rapidan) to the head-spring of the northern branch of the Potomack. In 1746, when Lord Fairfax arrived at Belvoir, an expedition of forty gentlemen was prepared to define the boundary and take formal possession. His lordship's agent, 
William Fairfax, accompanied the party, whose military leaders - for they expected to encounter Indians - were Captain Downes and Colonel Joshua Fry. Downes was a leading man in Orange County, whose Grand Jury once presented him "for Sabbath-breaking by travelling with loaded horses to Sharrendo." Colonel Fry, a mathematical professor turned soldier, was the commander whose death, in 1754, while on the French expedition, gave his young friend George Washington his first command. The surveyors of the expedition * were Thomas Lewis of Augusta County, and Robert Brooke, their assistant being George Fairfax. Brooke had been on the Spotswood exploration of 1716; he was grandfather of the famous Governor Brooke. Captain Downes had the management of the tents, and arranged a camp near Orange Court-house as the rendezvous of the company. Our first letter is from William Fairfax to Major Lawrence Washington, at Mount Vernon, who did not accompany the expedition.

“Fredericksburg, Sept. 9, I 746.

"Sir,

"We got here on Sunday evening, and all yesterday with some impatience waited the 
arrival of Colo Beverley and Colo Lomax. At night a negro man of Colo Lomax came to Mr. Jackson's with some baggage, and said his master and Colo Beverley were ready to set off when he came away. Colo Lewis, Mrs. Lewis, and Mr. William Lightfoot came yesterday, and bring account that your uncle, the Major, died yesterday sennight after a short illness. We are also told, with too great certainty, that Mr. Archibald Taylor of Norfolk lately drowned himself by voluntarily leaping into the creek at the Capitol Landing, rising suddenly from his bed at Mr. Nimmo's, who had a little before as they travelled saved him from another leap he had made into a Mill Dam, when he prepared and put a Brickbat into each of his Pockets, the better to sink him, with one of which he violently struck Mr. Nimmo on the Forehead for saving him against his will.

"September 10. Yesterday to our great satisfaction Col. Beverley and Col. Lomax came, and we are preparing to set off for Capt. Downe's this morning. I propose to make an essay and proceed as I find myself able, but run no Risque, and on the most probable Sensation of unfitness to Return. The weather is so sultry, and being neces- 
sarily obliged to go about this town to collect several things wanted, I have not yet seen Mrs. Washington. George has been with us, $\angle$ and says He will be steady and thankfully follow your Advice as his best Friend. I gave him his Mother's letter to deliver with Caution not to shew his. I have spoke to Dr. Spencer who I find is often at the Widow's and has some influence, to persuade Her to think better of your advice in putting Him to Sea with good Recommendation.

"By some mistake in the enquiry for them we have not got the Rundletts your Bro. made. I again repeat my Desires that you will continue your kind advice and assistance to Mrs. Fairfax, etc. etc., and visit as often as Leisure with Inclination will permit. I am always, dear Sir,

\section{"Your truly affectionate Parent "and faithful Friend,}

$$
\text { "W. FAIRFAX." }
$$

The next letter is from Robert Jackson, a citizen of Fredericksburg, and intimate friend of the Washington and Lewis families there - a godfather with George Washington of Betty (Washington) Lewis's first child. 
"Maj: Washington,

"FREDERICKSBURG, I 87 bre 1746.

"Sir: You will receive with this a letter from ye Honble Wm. Fairfax which he delivered me at ye camp at Henry Downes's the 16th instant where ye Comîssrs were met, viz. Cols Fairfax, Beverly, Lomax, Fry, and Major Hedgman and Mr. George Fairfax, together with their surveyors, aid du Camps, valet de Chambres, and a numerous train of Cavalry and Infantry, making all necessary preparations for a march, and this day or tomorrow expect they will decamp. They were all in top spirits, and Colo Fairfax in particular as cheerful as ever I saw him.

"They pressed me to stay a little longer with them, and must confess it was with reluctance that I left them, and Major Hedgman swore I should share the reward equally with him if I would go out.

"I stayed two nights with them where we regaled ourselves with good liquor in your tent seated after the manner of the Eastern Nations on Sophas of party collour'd Bristol rugs, etc.

"l am afraid Mrs. Washington will not keep up to her first resolution. She seems to intimate a dislike to George's going to Sea and 
says several Persons have told her its a very bad Scheme.

"She offers several trifling objections such as fond and unthinking mothers naturally suggest, and I find that one word against his going has more weight than ten for it. Colo Fairfax seems desirous he should go, and desired me to acquaint you with Mrs. Washington's sentiments. I intend shortly to take an opportunity to talk with her and will let you know her result. I am, Sir, "Yr most Hble Servt

$$
\text { "Rob. Jackson." }
$$

The names mentioned in these letters were those of great families, and nearly all of them are honorably inscribed in the history of their country. William Beverley, son of the historian, was a famous lawyer and county lieutenant of Essex. He was a member of the Council, and had at his house, "Blandfield," on the Rappahannock, now occupied by his descendant, one of the best libraries in Virginia. Lunsford Lomax, Burgess for Caroline, a commissioner at the Indian treaty of Logstown, was the founder of the family at Fredericksburg long represented by Judge Lomax, who, when feeble with age and illness, was 
carried to the polls that he might vote against secession. William Lightfoot, descended from John Lightfoot, a Jamestown colonist, was soon after a member of the Council. Major Peter Hedgman was a justice of Stafford, and a few years later one of those who resigned office rather than carry out the Stamp Act. The Colonel Lewis mentioned was Warner Lewis of Warner Hall, Burgess, who married the widow Gooch. Coming up from Gloucester, they could bring tidings of the death of Major John Washington, last of that generation of Washingtons, the time of whose death is ascertained by the above letter. Warner's father, John, had died November, 1745, aged 76 .

To Thomas Lewis, surveyor of Augusta County, one of the leading men on the expedition (which started out from Fredericksburg September 18, 1746), we are indebted for the subjoined notes concerning it. His journal, in possession of the Hon. John F. Lewis (formerly Lieutenant-Governor of Virginia), has never been published, though some extracts were given in a supplement to a portion of an edition of Waddell's "Annals of Augusta County." For these I am indebted to Mr. Brock, of the Virginia Historical Society. The camp was visited by "a great number 
of the neighboring gentlemen." On Sunday, September 14, the Fredericksburg party not having arrived, "most of the gentlemen went to hear Mr. Marshall preach, who returned with them to dinner. Several of us solicited him to preach us a sermon before we set off. He after making several religious evasions showed us the impossibility thereof, and so bid us farewell." (Marshall probably sympathized with the anti-Fairfax masses.) During the night of the 17 th there was a quarrel in the crowd that had gathered about the camp; they used fence-rails "with tolerable good success." "1 9 th. We set off from Captain Downs's with expectation of reaching head of Conoway that night. Col. Fairfax and Col. Beverley outrode the rest. We called at Hickley's and regaled ourselves with some very good cider. Night coming on we were obliged to encamp in the mountain before we got to ye spring head." " 2 oth. The mountains made such a dismal appearance that John Thomas, one of our men, took sick on the same and so returned home." "Oct. 3. This day several of the horses had like been killed, tumbling over rocks and precipices, and ourselves often in the utmost danger. This terrible place was called Purgatory." 
"Sunday 5. Our situation was such that we could not lie by. Our horses were starving; our provisions not being sufficient for us more than one day made it a work of necessity for us to press forward"- that is, to the camp; for this refers to a detached party. It would appear that the expedition divided, one party working to and from the Potomack, while Thomas Lewis, with the others, surveyed from the Conway. "Oct. 7. We were very much put to for want of water. We could find no other than a standing puddle wherein the bears used to wallow." "gth. Went to see Coburns who, with his wife and miller, a buxom lass, repaid the visit in the evening, which we spent very merrily." "I 4 th. This river [Looney's Creek] was called Styx, from the dismal appearance of the place, being sufficient to strike terror in any human creature.' They had a dreadful time crossing this creek. On the 28 th one of the men killed a buck with an axe. On' the 3oth, his Majesty's birthday, they drank his health, fired nine guns, and "concluded the evening in merriment." On November 13 the divided parties were together again, and "drank to his Majesty's and Lord Fairfax's health, which was accompanied with a discharge of nine guns to each 
health." Colonel Peter Jefferson appears to have been now with the party. On the 17 th the horses, tents, etc., were sold at auction. Of the party that went to the head-spring of the Potomack none kept a diary, and the commissioners' journal was lost from the Virginia State Library during the civil war. They reached the fountain of the Potomack on October 17, and there planted the Fairfax Stone.

On January 23, 1747, the commissioners assembled at the house of Colonel Peter Jefferson ("Shadwell," Albemarle) to draw plans of the Northern Neck. But they had to send all the way to Williamsburg for "paper and other things."

One little sequel of the expedition may be mentioned. While Thomas Lewis, who lived near Staunton, was on his visit to Fredericksburg, just before the expedition started, he probably saw a little lady whom he did not forget. This was Jane Strother, the friend and schoolmate of George Washington. In 1749 she married Thomas Lewis, and there is no greater genealogical honor in Augusta County, or in the valley of Virginia, than to be sprung from those two-whose home was many a time the pleasant shelter of General Washington. 
Lord Fairfax remained at Belvoir about two years, and amused himself with reading, fishing, and fox-hunting. He had with him one of the Cage family, son probably of William Cage, executor of Lady Fairfax, his lordship's mother. Among our manuscripts is the following (undated) note to Lawrence Washington at Mount Vernon :

\section{"Dear Sr}

"Wednesday Morn.

"His Ldship proposes drawing Mudd Hole tomorrow; first killing a Fox; and then to turn down a Bagged Fox before your door for ye diversion of ye Ladys; but I would not have you think that we shall stop a long time at yr door, for if yr dinner shou'd be ready by two then we shall pass through ye door and enter yr House. Mr. Bowles desires you wou'd send a Horse by ye Bearer. My service attends yr Ladys, and am $\mathrm{Sr}$

"Yr very Humble Servant, "J. CAGE.

"If you shoud chuse Friday for our coming lett me know. We took the Fox yesterday without Hurt."

Two of our Havemeyer manuscripts are in the handwriting of Lord Fairfax. They show 
that to lay the Fairfax Stone was one thing, and to secure respect for it another. The first letter is without superscription, but was probably addressed to Warner Washington, husband of Hannah Fairfax, an active agent of his lordship in Frederick (now Morgan) County.

"Sir,

$$
\text { "June I, } 1747 .
$$

"Having been informed that several Persons who go to drink of and bath in the Medicinal Springs near the Mountains of Cape Capon and River Potomack, within my Proprietary, do unnecessarily bark and cut down Timber Trees on the waste and ungranted Lands near the said Springs and the Mountain adjacent, more than useful for the erecting and building the Houses and Cottages required to shelter them, I desire You will in my Name use your best Endeavors to prevent such waste of Timber. And if upon your Application the said Persons will not desist, You will acquaint One or more Justices of Frederick County, requiring their Assistance towards restraining them. And if neither of these Remonstrances will avail, then to send me the names of such wilful Trespassers that 1 may proceed against them according to Law. 
fro

Greanag conff

Sonvenosefor the bift time reno

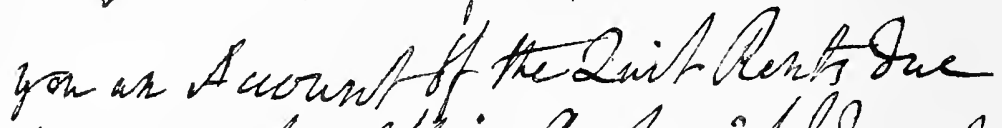
to we on the office Borki if lo not

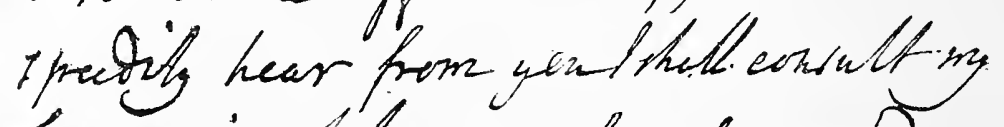

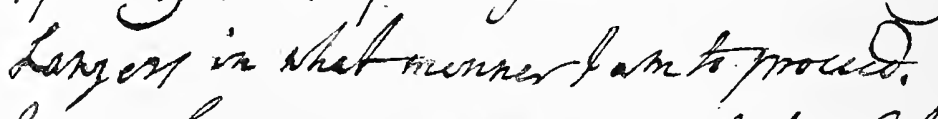

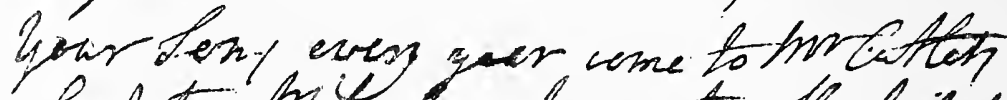
about two hity from hence to collest bit

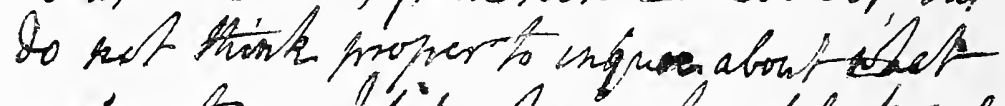

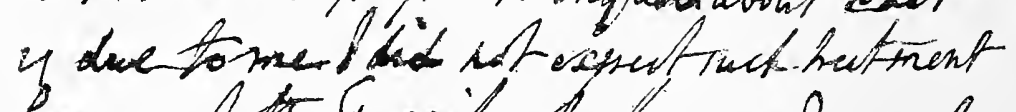

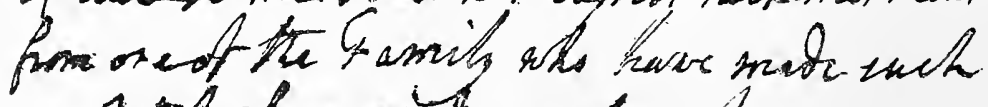

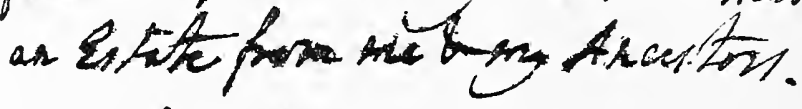

Memaix or

horrgtio19y3

Gourhwmble ferwant

Gavfar 
"You may assure the Gentlemen and Others that if the Waters continue to be useful in relieving the Sick I shall cause the Lands around the Springs to be surveyd, and a Number of convenient Lots laid off for a Town, also give all fitting Encouragement to invite People to inhabit and Settle there.

"Yr affecte Friend,

$$
\text { "FAIRFAX." }
$$

The land was duly surveyed by George Washington, who in the end became the chief landholder at the Springs. An immense white elm is still pointed out there as having been planted by Washington, the site of whose summer residence in the place is well known. But the town suggested by Lord Fairfax was not built until more than a quarter of a century later, and then not by order of his lordship, but of the republican Assembly of Virginia.

The other letter of Lord Fairfax, dated November 10, 1773, is given in facsimile. To whom it was addressed does not appear. It is pathetic to think of the lonely old bachelor, at the age of eighty-three, trying to attend to the business of his six million acres; for William Fairfax was dead (1757), and his son George 
William Fairfax, master of Belvoir, was wrapped up in public affairs. The old nobleman's realm steadily slipped away from him, and while his friend and former surveyor, George Washington, was fighting for American independence, the aged lord was still struggling in law courts for the principality set up by the Stuart dynasty in Virginia. Yet was he a fine old man, with many excellent qualities. It was his misfortune to live too long; the last words attributed to him were true enough - "It is time for me to die." They were uttered when he heard that Lord Cornwallis had surrendered to his former surveyor, George Washington.

Mr. C.S. White, clerk, writes me from Romney, West Virginia: "The Fairfax Stone is still standing at one of the head springs of the Potomac. It is said to be a hard sandstone marked ' $F$.' The stone is within about three miles of the town of Davis, on the West Virginia Central Railroad, in Tucker County." Another correspondent, however, tells me that the original stone has disappeared, its site being occupied by one set there by our government.

The Fairfax Stone was inscribed "FX." It should be in the pedestal of the Washington 
Monument, in Washington City: for Fairfaxland was lost in Washingtonland. The Fairfaxes remain among our worthiest Americans, but not an acre, I am told, belongs to one of that name in the State of which Lord Fairfax owned a fourth. Belvoir exists not, even in a picture. At the close of his life Washington wrote to Mrs. Fairfax in England: "It is a matter of sore regret, when I cast my eyes towards Belvoir, which I often do, to reflect that the former inhabitants of it, with whom we lived in such harmony and friendship, no longer reside there, and that the ruins can only be viewed as the mementoes of former pleasures." Greenway Court Manor, where Lord Fairfax so long resided, has also disappeared. Near it $£ 50$ in gold was found, which the old lord had buried, probably during the Revolution. The owner of six million acres had become anxious about even that sum!

Greenway Court was devised by Lord Fairfax to his nephew, Colonel Bryan Martin, with ten thousand acres, slaves, etc. By his mistress, Mrs. Crawford, who had been housekeeper for Lord Fairfax, Colonel Martin had a daughter, who married Captain Francis Geldart, R. A., to whom part of the estate was 
given. The residence was bequeathed to a Miss Powers, who lived there as housekeeper after his daughter's death.

Lord Fairfax died in 1782 , his $92 \mathrm{~d}$ year, and was buried under the communion-table of a church he had built in Winchester. When he first came to Virginia (1739), Winchester consisted of two cabins; he lived to see it a flourishing town. About fifty years after his burial the church was sold for mercantile purposes. Among the thousand skeletons indiscriminately carted away was that of the Right Honorable Thomas Lord Fairfax, of Leeds Castle, England, and Baron Cameron in Scotland, of Greenway Court in Virginia, proprietor of the Northern Neck of that colony. Undistinguishable now is the great man's dust from that of the humblest of those around him.

So ends the story of the Fairfax Stone, so resolutely set by the gallant young gentlemen of Virginia. Those who follow the points of it-the merry camp at Fredericksburg with little George, looking on, the setting of the Stone, the passing away of Belvoir and Greenway Court, the fate of Lord Fairfax, his dust and his estate-may find new significance in the shrine at Mount Vernon, and in the bril- 
liant capital bearing the name of his lordship's surveyor.

An apparition of lordship in Virginia was seen at the close of the century, when the Rev. Bryan Fairfax, son of William Fairfax and the Yankee lady Deborah, repaired to England, successfully claimed his title, sat once only in the House of Lords, and immediately returned as Lord Fairfax to his home, "Mount Eagle," near Alexandria. His departure and his return are represented in the following letters, hitherto unpublished:

"Dear Sir,

"Mount Vernon, 18th May 1798.

"Having occasion to write another letter to Sir John Sinclair, I take the liberty of giving you the trouble of it, and Mrs. Washington begs the favour of you to put her letter to her old neighbor and friend, Mrs. Fairfax, into a channel for safe delivery, if you should not see her yourself.

"Knowing, from experience, that Masters of Vessels never sail at the time they first appoint, Mrs. Washington and I propose to call upon you on our return from the City, in full confidence of seeing you then. If, however, contrary to expectation, the Captain of the Ves- 
sel you embark on should be more punctual than usual, and we should be disappointed in this, we beg you to receive our ardent wishes for a safe and pleasant passage to Englandthe perfect restoration of your health - and happy meeting with your family and friends when you return. To these wishes let me add assurances of the affectionate regard of

"Dear Sir,

"Your Obedt Servant, "Go Washington.

"Our compliments to Mrs. Fairfax and the family.

"The Revd Mr. Fairfax."

Mrs. Washington's letter was for the widow of Hon. George William Fairfax, who resided at Bath, where her husband died in 1787 .

The next letter is written by Hannah, wife of Warner Washington, the general's first cousin. She was the own sister of the Rev. Bryan Fairfax, now returned as the eighth Lord Fairfax. The residence of Mr. and Mrs. Warner Washington was "Fairfield," near Berryville (then Battletown), Clarke County. The "Lacey's" alluded to in the following letter was an inn half-way between their residence 
and Alexandria. The letter is written from "Mount Eagle," and dated December 7, 1799.

"I have the pleasure of informing my dear Son that I found his Lordship greatly mended though still weak.

"He had paid some morning visits to Alexandria, the day we got down. He has no legs left now, and indeed his whole body is greatly emaciated. We were very lucky as to weather and roads in our journey down. We left Lacey's (where I was told I should get to my Brother's funeral) before sunrise, and only stopped to feed, which enabled us to get to 'Mount Eagle' by 5 o'clock, - when we were agreeably surprised to find my brother in the dining-room. His Lordship has invited sixteen gents here today, so we are to have a feast, - all those who have paid visits since his arrival and during his illness. It is so long since I have conversed with Noblemen that it was very awkward the first day to address either my Brother or Sister by their titles indeed I have only got over the difficulty today. It began to rain hard on Wednesday Night, and has continued small rain ever since, though this is Saturday, which has made the roads extremely bad. I shall go to town on 
Monday and get the things for the Doctor against Tom gets down. The family join in love and good wishes to all in Fairfield.

"I am your affectionate mother, "H. WASHINGTON.

"To Fairfax Washington, Fairfield."

The Fairfax family in America is represented by a cultivated and unpretending gentleman, residing in the neighborhood of Washington City, who might at any time take his seat in the House of Lords.

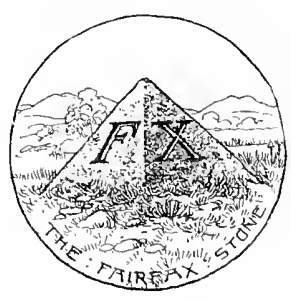




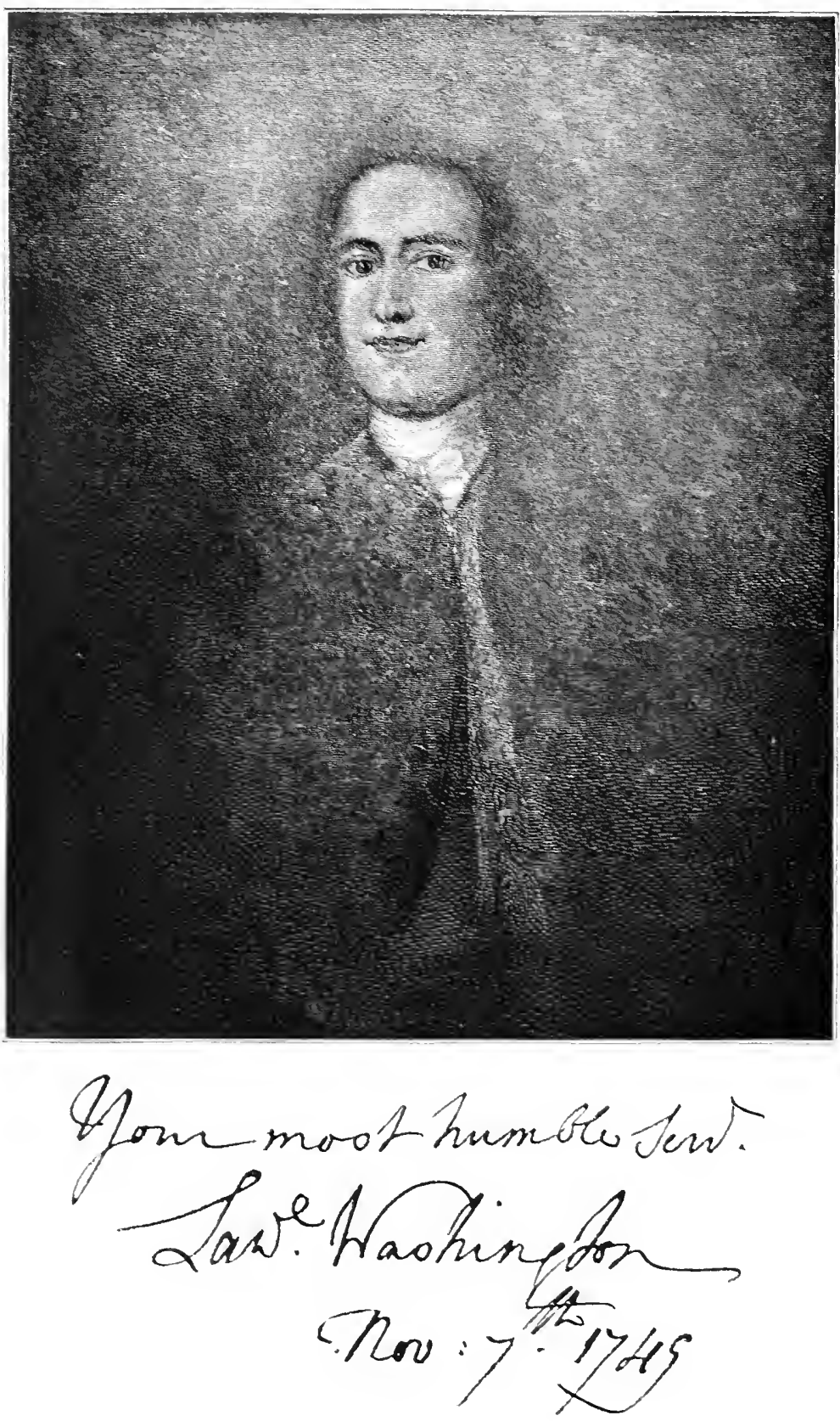


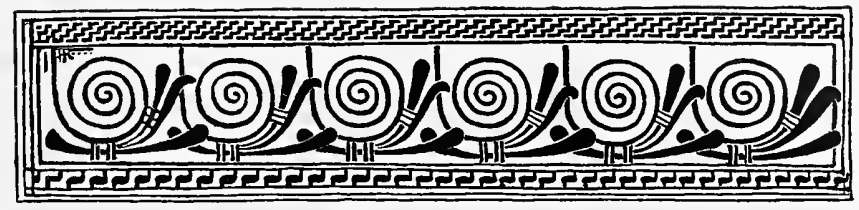

XII

Mount Vernon, and Young Virginia

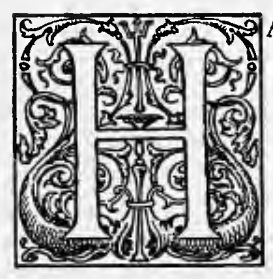

AD not the career of Major Lawrence Washington of Mount Vernon been cut short by death, in his thirty-fourth year, his would now probably be a great name in the American Revolution. Though only in his twenty-fourth year when he returned from Cartagena, he at once entered into public affairs, and was accorded high position. He was elected a member of the House of Burgesses, for Fairfax, in 1748 . There are indications that both he and William Fairfax, President of the Council, were too 
much in sympathy with Young Virginia and its enterprises to please Lord Fairfax. It is painful to trace along with the growing influence of Major Lawrence Washington the intimations of physical decline, partly due, no doubt, to the severe strain to which his constitution had been subjected in the Cartagena campaign, partly also to the loss of his children. His daughter Jane died in 1745, his son Fairfax in 1747, his daughter Mildred in 1749; and his little Sarah, though she survived him, he saw destined for an early grave. William Fairfax, himself bereaved, extends his sympathy to Major Washington in a note (much torn) dated October 2, 1747:

\section{"Sir,}

"As it has been the Will of God lately to take to his mercy the spirits of my late Wife and your child we must submit to his Divine Pleasure and take thence Tokens or Warnings of our own Mortality. I am glad you have resolved to carry Nancy to Fredericksburg, where she might find Relief both in Body and Mind. I will sollicit and endeavour to settle your Affairs [with] Lidderdale - and take care of yese. Portm ... Mr. Noden and Sally will go over on Tuesday ... What Rum I 
have to share you may $c$. . . Pay if I can dispense with Mrs. Clarke's last . . .

"I wish you and Nancy all Health and Happiness, being very truly, my dear Sir, "Your and Her most affectionate "W. FAIRFAX."

It is pleasant to find among our papers a letter from the Major's younger brother ("Austin"), residing at "Wakefield." The interesting seal is engraved on a previous page.

"Dr. Brother

"I hope by this I may be able to Congratulate you upon my Sister's Safe Delivery of a Boy. As the assembly setts next month hope you'll take this in your way. I am afraid we shall loose a friend in the Removal of the Seat of Government this Session by the Indisposition of Col. Lee who has been extremely Ill; he is now much better, but will not be able to go to town. Suppose you have heard Mr. Nimmo was Dead of the Flux, which is very Violent below, Six or Seven dying in a week in Williamsburgh. Commissary Dawson is extremely ill with it. I think his Honor ought to prorogue the Assembly till the town was Clear of such a Contagious Distemper. If you 
incline to Dispose of your land down here I wish you would lett me know it and the terms; there is several inclinable to purchase it. When you come down I wish you wou'd bring me the notes for the Tobacco made at hunting Creek last year and prospected at Ocoquan. My Wife joins with me in our Compliments to you and my Sister. I am Dr. Brother yrs most affectionately

"AUG'T. WASHINGTON.

"To Majr. Lawe. Washington

"In Fairfax County.

"August 28, 1748.

$$
\text { "Pr. Jupiter." }
$$

The land alluded to in the preceding is applied for by Lawrence Butler in our next letter. The Washingtons and Butlers were ancient neighbors and friends in Virginia. In 1698 Ann, widow of Captain John Washington, son of Colonel John the immigrant, gave power of attorney to her "trusty and well beloved friend Mr. Caleb Butler," and this lawyer's daughter was the first wife of Captain Augustine Washington. Lawrence Butler, the son of Caleb, was, therefore, the uncle of Major Lawrence Washington. He was also godson of the major's grandfather, Lawrence, who be- 
queathed him a young mare, two cows, and I 37 acres - probably adjacent to the land he desires to buy from Major Lawrence Washington. He may have succeeded, as no Westmoreland land is mentioned in the Major's will four years later. The letter is marked, "By favour of Mr. A. Washington" (Austin). It must be added that the seal is an indecent device, nicely cut, surrounded with the words "No immodesty."

"Dear Sir,

"I am sorry it should be in your power to tax me with a Breach of promise in not coming up to your House, the occasion of which is: since parting with you am summon'd to the first day of General Court; which is so Nigh hand that it cant well be done now; but when the assembly Rises which I presume will be about Christmass, then, if your Brother Augustine is agreeable, will wait on and spend a fortnight or Three Weeks. I assure you my Friend I shall be proud to keep up that Friendship which has been so long United between that [?] of your Worthy Ancestors and my Father, long before our memory; And as I am no ways conscious why that Friendship should not subsist as our forefathers did I know 
not; and it is my earnest wishes that it always may to the end of time. However I shall withdraw from that subject Else peredventure you may look on it as a piece of flattery, but, as it is a thing I cant enjour, hope you will look on it as nothing more than the truth of a sincere Friend.

"However give me leave Sir to fall on another subject; which is, I have a great desire to purchase the Land we were talking of, but your price was when we talked the matter most extravangty, and since upon looking and Enquiring into the Land find it not Nigh so Good as the character, but as I want a seat on the Water to Build would give more than the Intrinsick Vallue just for fancy ; therefore will make you such proposals as I make no doubt will be agreeable; that is, I will give you Six hundred and fifty pds Current Money in the following manner; that is, five hundred pounds by ist April and the Ballance as you told me four years after, otherwise will pay you Twenty Shillings Current Money per acre, and make my payments in proportion to the other offer, which to be sure you nor no man can think but that is sufficient, as you very well know most of the Land is clear'd and worn out quite so much that some of your 
Tenants are obligd to Rent other Land to make Corn or else buy ; besides there is a good deal of it Barrens not worth five shillings, so that I must be of Opinion that when you come to Consider my offer you will think it is sufficient. I shall be glad to have your result by your Brother and shall conclude only wishing you in a better state of Health than when we parted, which is the sincere wishes of

"Dr Lawrence your assur'd Friend

"and Hble Servt

"27th Sepr 1748."

"LAW: BUTLER.

The exploration of the western region of Lord Fairfax's estate, and of the upper Potomack, and the maps made and circulated (long before they were printed), awakened Virginians to the reality of a Great West. While Joist Hite and his partners were battling with his lordship for their claims, the majority of young Virginians felt that if they were to secure land they must adventure into new regions as their forefathers had adventured into Virginia. In 1749 the Ohio Company was formed; the twenty shareholders comprised men now famous in Virginian, and some in our National, annals. The company obtained 
a grant of six hundred thousand acres west of the mountains and south of the Ohio. Christopher Gist was sent out to survey the region, and to establish and fortify a settlement at the spot now known as Pittsburg. Those who would now study that enterprise will find some fresh information in the newly published biography of George Mason, by Kate Mason Rowland,-a useful contribution to American history. While Christopher Gist, the first white settler west of the Alleghanies, was cutting out there the first roads, Col. Thomas Lee, President of the Council, was engineering the company in Virginia, and several agents were attending to its interests in London.

Major Lawrence Washington was among the original organizers of the company, and it was on that business, probably also with hope of benefit to his health, that he visited England. We have here two letters written to him while there by William Fairfax.

"Sir,

"BelvoIR, $17^{\text {th }}$ July 1749.

"Soon after I rec'd your letter by Ben, I gave my Lord the letter you left with me: He read and put it into his Pocket without saying anything then or since. Notwithstanding the 
Land Office for Frederick Co'ty has been Shut chiefly on Acct of Messrs. Joist Hite and Others concerned, they are now come to an open Declaration of seeking elsewhere for Relief, and have Sent Abram Hite to Mr. Mercer for Council in Hopes of getting Some Kind of Injunction, and a Petition is going about to enable Colo Wood and said Hite to go and Solicit his Majesty not to consent to the late Act of Assembly which explains the Word Grants to mean only such Grants as have passed under the Seal of the Colony.

"As you had no certain Prospect when You was to sail with the Governor [Gooch] the Passage you and Mr. Carter took with Capt. Kelly a good naturd man was well undertaken. According to Desire I now enclose your Second Bill, and when at Williamsburg shall endeavor to get and send you a Bill of Excha: on Acct of yr half Year's Salary, under cover to Mr. Price in Bush Lane.

"What relates to the Sales of the Lots in our new Town will be communicated, together With a Plan thereof by your Bro: George. I went over the 15 th inst. to pass Saturday night with your Dame, Brothers Austin, and George, and Sister Betsy; On Sunday Mr. Carlyle and Sally, G. Fx his Consort and Miss 
Molly joynd us and you cant doubt but We unanimously toasted your and Mr. Carter's good voyage, and that every Felicity may be your Attendant. Perhaps when you go to London you may find Mr. R. Noden inclinable to see Maj. Fx. If so, desire his favorable Introduction. By the Character I have, He will receive You with genteel Freedom. I am not personally acquainted, or would send you a Letter.

\section{"I am \&c \&c \&c}

"W. Fx."

The "new Town" alluded to was Alexandria, originally Belhaven. "Sally" is Sarah Carlyle, daughter of William Fairfax. "Miss Molly" is Mary Cary (afterwards Mrs. Edward Ambler), sister of Sally, wife of George Fairfax. "Maj. Fx" is Robert Fairfax of Leeds Castle.

The next letter of William Fairfax to Lawrence Washington in England is as follows:

"Sir,

\section{Fairfax Coty 15 August 1749.}

"Our Principal Occurrence in this County Since your Departure has been the Election of our Vestry, a copy of which is enclosed. 
Maj.. Osborne was strongly opposed by the Parson's Interest, who again insinuated my Lord and Family's Intention to build a central Church of extraordinary Expense. Colo Colvill had so few votes He supprest the Number. "You will a little wonder if Colo Philip Lee should present you this Epistle in London. By his Father's Letter to me I understand it was a Sudden Resolution to go with Sr Wm. $\mathrm{G}[\mathrm{ooch}]$. Nat. Smith, who calls for this in Expectation of going also, has so little Time Nancy cannot write. I heard from Mount Vernon this morning.

"I wish you every Satisfaction and a glad Sight of Tommy.

$$
\begin{aligned}
& \text { "Yr very affecte Friend, } \\
& \text { "W. FAIRFAX." }
\end{aligned}
$$

The enclosure, a list of the twelve successful candidates and the unsuccessful, in George Washington's writing, and with his signature, follows :

"1 749."

"Vestry, Truro Parish

Hugh West, Ordy . . . . . . 255

Jera Bronaugh, Sheriff . . . . 248

James Hamilton, Ordy . . . . 228 
Charles Broadwater . . . . . 224

Geo: Mason, no Resident . . . 232

William Payne, no Freehold . . 200

Thomas Wren do . . 192

John Furley . . . . . . . 189

William Peake . . . . . . . 207

Daniel McCarty . . . . . . 220

Abram Barnes . . . . . . . 196

12 Robert Boggess, Ordy . . . . 192

John Minor . . . . . . . . 180

John West . . . . . . . . 165

Henry Gunnell . . . . . . . 158

Thos Ford . . . . . . . . 152

William Elzey . . . . . . . 107

George Fairfax . . . . . . . 115

Benjamin Sebastion . . . . 103

Richd Osborne . . . . . . 84

James Donalson . . . . . . 67

Sampson Furley . . . . . . 67

Joseph Stephens, little known . $4 \mathrm{I}$

12 Colo Colvill

$$
\text { "Copy "G. Washington." }
$$

The parson whose "interest" had defeated Major Osborne's aspiration for the Vestry, was the Rev. Charles Green, mentioned in 
my fourth chapter. I suspect that he must have been previously a clerk, for he was a physician, and continued medical practice to the end of his life (1765). He was the family physician at Mount Vernon, after George Washington had come into possession. "Hugh West," says Miss Rowland, "is enumerated with the Alexanders, Fairfaxes, and Lawrence Washington in the act incorporating Alexandria in 1748 , and the town was built on the land of Hugh West and John and Philip Alexander. One family of the Wests in Virginia is descended from a brother of Lord Delaware whose family name it was." Major Osborne, an original trustee of the town, died in February, I750. The McCartys and Bronaughs were connected with the Mason family, and men of great influence. Benjamin Sebastian was a clergyman. All of the men in the list were active in county affairs. Although George Mason is described as "no resident," this was overlooked. He was no doubt living at his mother's house, "Chappawamsic," but probably already building Gunston Hall, in Fairfax, for the wife whom he married the following year. ("Life of Mason," I, p. 84.) Colonel Colville would appear to have been 
an opponent of the Fairfax interest, but in after years was a friend of General Washington, who was executor of his estate. This appears by a letter of the general to Bushrod Washington, printed in my "George Washington and Mount Vernon," p. 328. I am indebted to Miss Kate Mason Rowland for assistance in making these brief notes, which may give my reader some idea of the agitations surrounding Major Lawrence Washington and William Fairfax.

Mr. Elzey, defeated at the Vestry election, was the opponent of George William Fairfax in a contest for the House of Burgesses which is said to have brought George Washington his first political experience, namely, a personal encounter with William Payne, whose name is in the successful list. Mr. Cabot Lodge, in his "Life of Washington," indignantly repudiates this story; but it is related by the Rev. Dr. McGuire, who married a relative of Washington's, and does not appear to me improbable.

"His warm friendship for Col. Fairfax brought him in collision with a Mr. Payne, the friend of Mr. Elzey. In consequence of some offensive language into which he was betrayed towards Mr. Payne, that individual 
struck him with a stick, and so violent was the blow that it knocked him down. . . . He [Washington] wrote a note to Mr. Payne requesting that he would meet him next morning at the tavern, as he wished to see him with reference to their recent disagreement. Payne, in expectation of an unpleasant interview, repaired accordingly to the appointed place, and, instead of a hostile meeting, found Washington prepared to acknowledge his fault and solicit pardon for the offense given in an unguarded moment."

It speaks a great deal for George William Fairfax that, though nearly six years older than George Washington, he became his comrade. He appears to have been trained for the work of surveying, probably because his father (William) saw the great need of it on the estates in his charge; and when George Washington had learned all that the Fredericksburg school could teach him in that direction, George Fairfax employed him as an assistant on the great survey, of which the boy (just sixteen) has left the graphic account recently edited by Dr. J. M.Toner. (Munsell.) Thenceforth he was devoted to George Fairfax, and perhaps the only political canvassing in which Washington ever engaged was to 
carry his friend to the House of Burgesses. George William Fairfax first entered the House just after the survey mentioned, giving up his place as surveyor to George Washington. In December, 1748, he was married to a famous Williamsburg belle, Sally Cary, who also became fond of George Washington. She brought with her a sister, Mary, to whom George alludes in one of his letters as "a very agreeable young lady," who, however, only "revives my former passion for your Lowland Beauty" (Betsy Fauntleroy). Thus, if old Lord Fairfax had been disappointed in love (else how could he resist the Virginia beauties?), there was another bond between him and his young surveyor. The ladies at Belvoir tried to beguile the love-lorn youth even by flirtation - as appears by a letter found in the desk of Mrs. Fairfax after her death, in extreme age, in England. Long years after the charming circle at Belvoir was broken up, Washington defended from confiscation the property of his friend George Fairfax, whose real loyalty to America he affirmed.

It has been repeatedly stated that, in marrying Sally Cary, George William Fairfax carried off his friend's sweetheart, but it is demonstrably certain that Washington never 
met her until after her marriage. In this connection I will copy here a curious legend of the Fauntleroys from a private letter written by a great-granddaughter of Washington's "Lowland Beauty":

"About the year 1690 a young French prince, heir to the throne, formed a morganatic marriage with a young French gentlewoman, Lady Eliza Bellefield, of good family but not of the blood royal. Somewhere about 1700 the Prince of Saxe-Meinigen was also married ad morganaticum to Elizabeth Schurman, and petitioned the Emperor, Charles VI., to give her the title of Princess, and confer the right of succession on her children. This raised a storm in the princely world, which ended in the decision of the leading lawyers that such a marriage as a civil engagement was binding, but failed to confer on the wife the title or fortune of her husband. But long before that result of their combined wisdom was known, Lady Bellefield had died of chagrin, and her three sons were banished from France. They came to Virginia about 1706 , bringing with them their princely title, Enfant-Le-Roi, and coat of arms, three infant heads crowned with fleurs-de-lis. Miss Betsy was named for and 
was the granddaughter of Lady Eliza Bellefield." (According to this correspondent, Betsy did not marry an Adams, as I have stated, but a Fauntleroy.)

Next to Colonel Thomas Lee in official management of the company was Major Lawrence Washington, and it is with much satisfaction that I find in the Havemeyer collection a letter of his, the only one I have seen from his hand. It was written apparently to some high official in England, and is without date - also without much punctuation. Although written with the haste of which it speaks, the writing is clear and the statements are lucid.

"Sir,

"In compliance to your desire I have drawn an imperfect scatch of the Ohio etc. by which you may form some Idea how the Branches of that River and Potomack interlock.

"Potomack River is navigable for small Flats as high up as the Aligany Mountains except an obstruction of seventeen miles imediately above where the Tide flows which is described by the two sides of the River uniting in my scatch.

"The Ohio is a dull River and admits an easy Passage for Flats or Canoes within seven 
miles of Lake Erie and by the Branch called Yohiogana within forty-five of the head of Potomack and the Mountains on Savage River admitting an easy Passage through makes the communication between those two Rivers very easy.

"Wood's River breaks thro' the Aligany Mountains and has its first Source near Roanoke and is the Branch Howard and his Party went down about seven years ago when they were made Prisoners; there are several Germans setled on the head of it to the Eastward of the Aligany Mountains.

"The Lands on Ohio and its numerous Branches are described by all our Traders as vastly rich. The Banks of the River expose Coal in most parts to view. The Indians bring Salt from some Place as yet unknown to our Traders. There are numbers of large Plains clear of Trees and cover'd with white Clover. The Country is generally very level and the River affords Fish in great plenty. There are many more Branches of the Missisipi So of the Ohio that take their rise out of the same Ridge of Mts. On one aback of Carolina live the Cherekees and on the back of Georgia the great Nation of Indians the Chekesaws and still more So the Creek Indians they live in 
North Carolina but not on the Branches of the Missisipi. The Ohio is inhabited by the Nations tributary to the Six Nations to whom during the War many Indians Friends to France heretofore join'd. The French have no Setlement nearer than the Mouth of the Ohbash [Wabash]. The Lands on Lake Erie are said likewise to be very fine.

"I have now describ'd in an imperfect manner owing a litle to the hurry 1 am now in, the Country aback of Pensilvania Virginia and Carolina and shall now add my thoughts on the advantage arising by a due encouragement to the speedy Setlement thereof.

"The Skin Trade ever has been deemed a beneficial one to all Nations whose Dominions or Course of Traffick would permit them to carry it on. The English have had the French their great Rivals herein who by claiming what I apprehend in nowise belongs to them have prevented our Traders penetrating further into the Country nor indeed could they otherwise well have done it for want of proper places of security on the Ohio for their Goods it being impossible to send to Philadelphia or Virginia every time they want Goods to sort their Cargos without the loss of so much time and expense as distroy'd the Trade this Evil which 
is a very great one and which I have heard the Traders complain much of will be remedied by the Scheem the Ohio Company are intending to pursue who propose keeping a large Qy of Goods at the joining of the Ohio and Monongala in a Fortified Store which are to be sold the Indians or Traders at a moderate advance and can during any season of the Year be easily procured by the out Traders who follow the Indians many hundred miles during the Hunting Season. It appears evident (and is so in fact) that the Trade can be better supply'd from the Head of Potomack than any other way the navigation from Europe being much safer and shorter and the Land Carriage very easy.

"That its the Interest exclusive of Trade to get possession of that extensive Country I believe no one doubts and so I shall say litle more than that the further we extend our Frontier the safer we render the Interior Dominions and the French having possession of the Ohio might easily invade Virginia etc. for our Mts. are not so formidable as to be much security, and that it can be never better timed than now when the Indians are our Friends and would assist by proper encouragement in securing any Setlement the Crown would 
think proper to make and nothing can more contribute to keeping them our Friends than contriving them the necessaries of Life at the easiest rates which the setling the Ohio will effectually do; The Indians being no Geographers esteem those the honestest who sell the cheapest and was the reason why the Indians on Ohio proclaim'd War against the French who were so distressed in their Trade as not to be able to supply the Indians on reasonable Terms, neither can they ever do it the navigation up St. Lawrence being very dangerous as likewise there are places they are obliged to unload and carry over land from St. Lawrence to ye Lakes and then the Current in some places is vastly strong and on the Lakes very wild and dangerous so that I think the head of Potomack the safest and easiest way the Indian can be supply'd.

"If his Majesty would ingage the Indians by annual presents it would certainly be the most speedy method of setling that Country for no Persons will dare to live there without being well convinced of the affection of the Indians. Germany will readily afford inhabitants etc.

"I have so litle time at command that I am forced to leave off without even being at lei- 
zure to read over what I have writ, but if it can convey to you any of the Ideas I have of the usefulness of the setling the Ohio it answers my end and I hope you will excuse the rest. I am

$$
\begin{aligned}
& \text { "Your most humble Servt } \\
& \text { "LAWE WASHINGTON } \\
& \text { "Nov: 7th, I 749." }
\end{aligned}
$$

The Wabash is called Obash by Governor Dinwiddie (1754). "Wood's River" is now the Great Kanawha. It was discovered by Abram Wood, who crossed the Blue Ridge at "Wood's Gap." On Fry and Jefferson's Map it is called "Great Konhaway, called also Wood's and New River." (Dinwiddie Papers, l, pp. 62 and 282.) It was probably from the Kanawha salt-licks that the Indians got the salt to which Major Washington alludes. His appreciation of the coal-field is notable.

Among those interested in the Ohio Company was the London merchant Robert Dinwiddie, afterwards Governor of Virginia. Dinwiddie had in various ways been connected with the colony,- - as trader and as inspector of customs, - and was well acquainted with the Washington and Fairfax families of Virginia. On the death of Thomas Lee the presi- 
dency of the Ohio Company devolved on Major Lawrence Washington, to whom the following letter was addressed, "Pr Collo Fairfax," beneath this name being the incomprehensible letters "D. D." Colonel William Fairfax had passed a year in England.

"Dear Sir,

"LONDON, 20 $0^{\text {th }}$ March 175\%

"Having so good an oppty as yr Father in Law Collo Fairfax, I embrace it to acquaint you of the receipt of yours by him and one since. The last gave me pleasure, that the Dutch wanted 50,000 acres of the Land granted to Ohio Compy, and observe what you write about their own Minister, and to endeavour to have them freed from paying to the Church of England. I fear this will be a difficult Task to get over, and at prest the Parliamt is so busy with public affairs, and the Ministry in course engaged, add thereto the Indisposition of our friend Mr H.y., that we must wait some time before we can reply but be assured of my utmost endeavours therein.

"The Death of my good friend Collo [Thomas] Lee, gave me real concern, as he was a person ggreatly Valued, and indeed the Ohio Company have lost a Worthy manager, but 
as the last in course devolves on you, I have no doubt of your Exerting yourself therein if your health will allow of it, it will give me a sensible pleasure to hear of your confirmed good state of health.

"As to news here I refer you to the bearer who can tell you more fully than I can write. I begg to hear from you as soon as possible, and if I can be of any service to you freely Comand

$$
\begin{aligned}
& \text { "Sr yr most obedt hule Servt, } \\
& \text { "RoB' DinwidDiE. }
\end{aligned}
$$

"My Wife joins me in kind respects to your Lady and family.'

The "Mr H.y." alluded to was John Hanbury, a great London merchant, an eminent Quaker, and an original grantee of the Ohio Company. He died in 1758 . The above letter is, I believe, the earliest known from Dinwiddie. In the collection is also a letter of earlier date than any yet published from the great Virginian, George Mason of Gunston Hall. He was among the most active promoters of the Ohio Company, and this letter, "pr favour of Mr. Parker," was addressed to the new manager, "Major Lawrence Washington, Fairfax County.' 
"Dear Sir,

$$
\text { "May 27th, } 1750 .
$$

"As the Gentm Mr. Parker offers for Security are utter Strangers to Me, I cannot take upon Me to say whether I think them sufficient or not; but as Mr. Parker's Affairs are circumstanced, I imagine they are the only Security He can at this Time give, and therefore I most readily concur in the same Opinion with You, that it's better to accept them than delay sending up the Goods any longer; for we have already given to our Rivals the Pennsilvns too many Advantages over us by suffering them to engage the Interest of the Indians, and raising in them numberless Prejudices against the Ohio Compy. While We, instead of fulfilling our Engagements and complying $\mathrm{w}^{\text {th }}$ our Promises in Supplying them wth Goods, have lain quite still, as if we were altogether unconcerned in the Matter; for these Reasons I shou'd look upon anything that put stop to the Trade for this Season, as utterly destructive of our whole Scheme, and think it ought carefully to be avoided; and I have really so good an Opinion of Parker that I can hardly think He'll offer to defraud us; besides l believe his All depends upon discharging this Trust with 
Honour and Integrity.-But as the Company have ordered that he shou'd give Security, and have relyed upon us to take it, we ought by all means to observe their Directions; and I make no Doubt, let the event be what it will, that they will approve what we have done; as they must be convinced We act upon no other motion than the Interest of the Company.--I therefore agree to accept the Security Mr. Parker offers till a Genl Meeting of the Company, at wch Time they may accept or reject them as they think proper,but I hardly think the Instrument of Writing Mr. Parker showed me authentic, and am of Opinion they ought to bind themselves $w^{\text {th }}$ him in a Penal Bond under their Hands and Seals; but as this cannot be done imediately I suppose there can be no Risque in letting him have a Load of Goods now, and desiring him to have such Bond signed agst he comes down again. Had Mr Chapman been at Home, I shd have consulted him upon it; as he is not, I give you my own sentiments, and am wth my comps to the Ladys "Sr Yr most humble servt "George Mason.

"I wrote to stop our second Cargoe till next Spring." 
The Chapman referred to was Pearson Chapman, whose residence was in Maryland, between the spots afterwards occupied by Washington and Georgetown, and just opposite Gunston Hall. Not far from the Chapman's was "Mattawoman" (on the Maryland side), from which house the above letter was probably written; for, a few weeks before, this young Virginian had become the happy husband of Anne, daughter of Colonel Eilbeck of "Mattawoman" - the young lady being already, at sixteen, famed for her beauty.

Early in the year 1750 William Fairfax, accompanied by his son-in-law, Major Carlyle, visited England, and we have two interesting letters written from that country to Major Lawrence Washington. The first is dated at Whitehaven, July 6, 1750.

"Sir,

"As I was several times Seasick in our Passage your Bristol Water and the good plumb Cake as often entertaind me agreably, and used with that care as to bring some of Each hither. Mr. [Joseph] Deane soon came and kindly invited Us to dine with him where Mrs. Deane joynd in a friendly Enquiry after yours and Nanny's Welfare. This Town is 
dayly encreasing in its building of Houses and Shipping. Sr James Lowther is at London attended by his Physicians. All the Gentlemen appear very complaisant. We lodge at Mr. Hicks', and propose setting off with Him on Monday to visit Mrs. Hicks at Pap Castle in our way to Carlisle. When I din'd at Mr. How's, he gave Me the enclosed Advertisements assuring that if our Planters would not conform to tye up their Tobacco in Hands or Bundles as the French insist, their Agents are directed not to purchase. I suppose that Alteration will not appear to give any extraordinary Trouble especially as the French Market demands it to be so handled. You will therefore please to recomend the Consideration thereof to your Friends and where you can influence.-Pray tell Nancy that I shall not forget her Tokens upon my Arrival in London. We set off for Carlisle to morrow to visit Mrs. Carlyle, thence to Kendall and York, where my Stay will be uncertain; however if yue have any Thing for me to negotiate for yue in London yue may direct for me at Mr. Noden's. I have writ to my Lord Fx, desiring Him to acquaint me wherein I have given cause for so much coldness as He Seemed to treat me, yue and Mr. Carlyle, for it would give me real 
concern to have it continued, which would embitter the Satisfaction your Neighbourhood would otherwise enjoy. And my Stay in England would 'be rendered more agreable, on hearing that a good Harmony was promoted and maintained in our Familys. - We did not fail in our Passage to remember yue all at $\mathrm{Mt}$ Vernon in our Toasts. Hoping Sally [Carlyle] has got a pretty Boy to dandle till his Papa returns and relieves the Sport, With kindest Love to yue all and Friends, I am Dear Sir, "Your affecte Parent

"and faithful Friend, "W: FAIRFAX."

The next letter is addressed "To Lawrence Washington Esqr ; at Mount Vernon on Potomack River Virginia."

\section{"LonDON I $2^{\text {th }}$ October 1750.}

"Sir,

"I had the Pleasure to receive your two Letters which relieved an anxious Suspense $\mathrm{Mr}$ Carlyle and I were under on Accot of being told of Sally's dangerous Symptoms in a cancerous Breast. You'l do Us Justice in thinking that your present Narration of her expected Recovery has only made our Enjoyment easy 
and sometimes cheerful. I have not been interrupted in my Travel and Visits by any confining Disorder, and hope even the Winter approaching will not prove too severe in its chilling Attacks. - I am kindly lodgd and entertaind at Mr Noden's where I have seen the Earl of Haddington lately married to Mrs Loyd and appear to be an affable and happy couple. They are preparing to set off for Scotland there to live with a noble Spirit but becoming Oeconomy. The present weather is rainy and cloudy which prevents my going dayly abroad. Majr Fx. is expected in Town next week. I have not visited $\mathrm{Mr}$ Bladen yet but intend it soon. I am sorry Lord Fx. continues to show his Dislike as None of our Family have given just Occasion; And I trust G Fx. will not do any Thing willingly to Offend so as to make a Pretext for the intended Removal you mention. Then if such should happen We might with better Reflection endeavour to make the Best of it. As to Household Linnen \&c expect to carry some with us having talkt with Mrs Carlyle about the Want G. Fx may be exposed to, even before We can arrive in the Spring. I have wrote to Col. Cary for his kind assistance. I shall be glad to hear that your Bro. and Self received Benefit at the 
Springs. I am much pleased with my Coming for as well in Yorkshire as here I have renewd that good Acquaintance, as I trust G Fx. and my other Family may derive some Advantage. I am dear Sir

"Yrs and Nancy's very affect Parent "W: FAIRFAX."

"Mr. Bladen" was the uncle of William Fairfax, an eminent classical scholar, who became one of the Lords of Trade.

With these letters this book may draw to a close. They leave us with a feeling that interesting facts remain undiscovered in the early history of the Washington and Fairfax families. George Washington himself wrote to the Earl of Buchan that there had been "intermarriages" between the Fairfax and Washington families before they came to America, but only one has been discovered - that of Henry Fairfax, father of William, with the sister of Mrs. Henry Washington of South Cave, Yorkshire. No connection between these northern Washingtons and those of Virginia has been made out, yet William Fairfax's letters suggest their acquaintance,

\section{H. $70 \quad 89$}





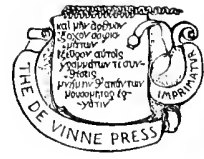




\section{(a)}

$5 y^{2}$

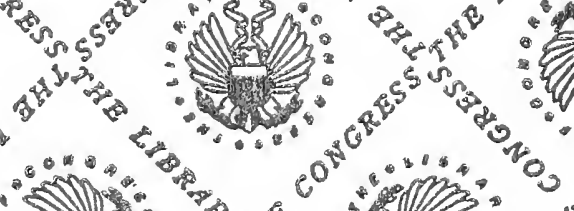

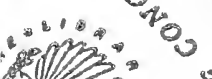

政



:

$30 \% 40.50$

is $\cos ^{\circ}$

क

in

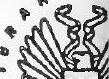

(5)

in

बर्षे

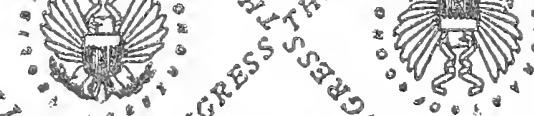

anc

Q20,

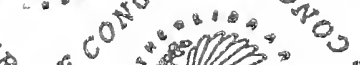

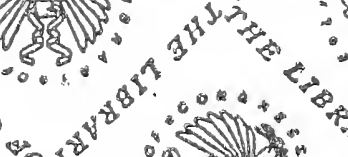

40

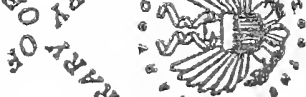

2

COSI.

Ps

\&

$\cdots+v^{\theta^{3}}$

$+5$ $5 s^{4}: 0$ $5^{5} n_{3}$

हु

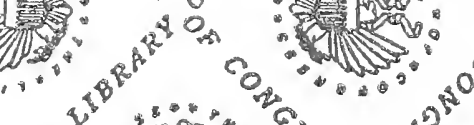

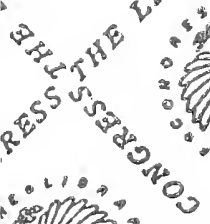

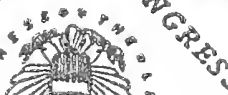

$300^{\circ}$

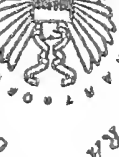

$\sin 5^{2}$

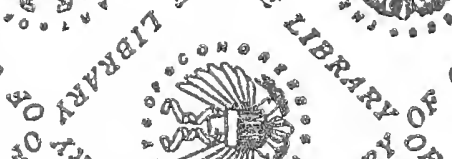

$6^{\circ}$

-

8

.

s.

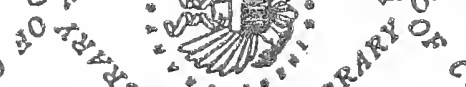

pi:

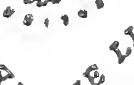
${ }^{4} 0^{2} 0^{\circ}$ ${ }_{20} 0^{0}$

\% $0^{40} 0^{0}$ 3. $\mathrm{C}^{2}$

o 4.25

(2) *

$\psi^{8} \cdot{ }^{2}$ $5^{5} \sin ^{n}$

* flo

in $5^{3^{2}}$

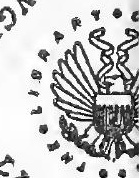

3 a

-

का

0

ifles.

बक से

sजu-

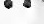

$0 . \mathrm{r}_{2}$

- 2 in:

20 40 
\begin{tabular}{|c|c|c|c|c|}
\hline \\
3
\end{tabular}

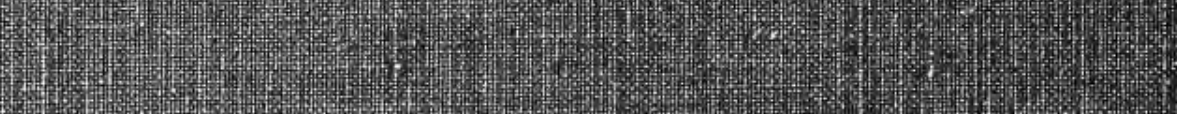
(5)

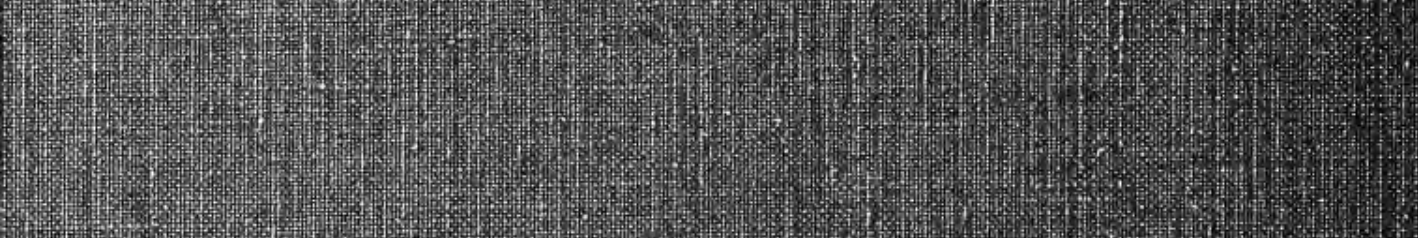

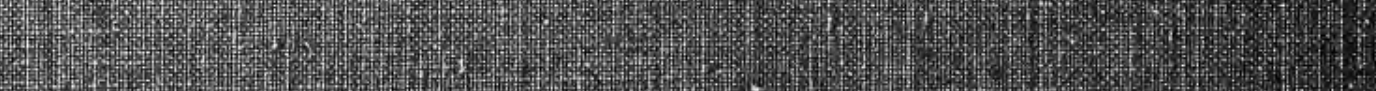

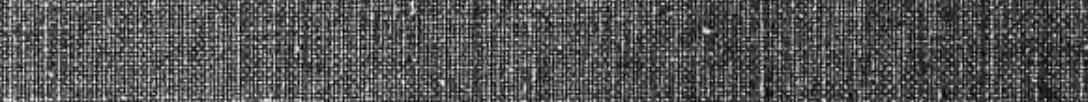

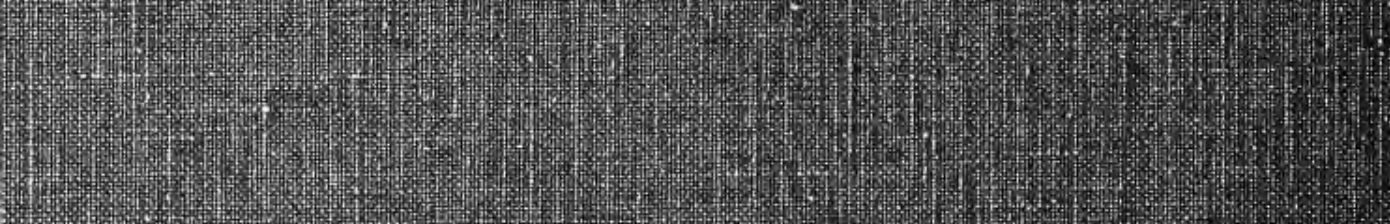
this
14:
14.
ting

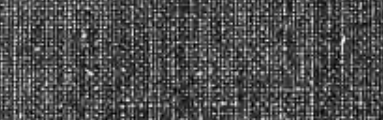

\begin{tabular}{|c|c|c|}
\hline &
\end{tabular}

(19)

(5)

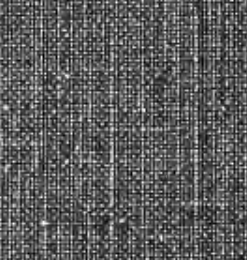

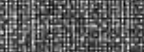

(1)

(1)

(1)

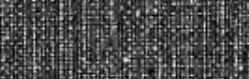

-

(2)

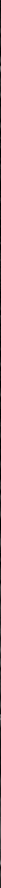

